CHRISTIANE BEZERRA DE ARAUJO

NOVO PEPTÍDEO INTRACELULAR DERIVADO DA CICLINA D2 INDUZ MORTE CELULAR

Tese apresentada ao Programa de PósGraduação em Biologia Celular e Tecidual do Instituto de Ciências Biomédicas da Universidade de São Paulo, para a obtenção do Título de Doutor em Ciências.

São Paulo

2014 


\section{NOVO PEPTÍDEO INTRACELULAR DERIVADO DA CICLINA D2 INDUZ MORTE CELULAR}

Tese apresentada ao Programa de PósGraduação em Biologia Celular e Tecidual do Instituto de Ciências Biomédicas da Universidade de São Paulo, para a obtenção do Título de Doutor em Ciências.

Área de Concentração: Biologia Celular e Tecidual

Orientador: Prof. Dr. Emer Suavinho Ferro

Versão original 
DADOS DE CATALOGAÇÃO NA PUBLICAÇÃO (CIP)

Serviço de Biblioteca e Informação Biomédica do

Instituto de Ciências Biomédicas da Universidade de São Paulo

reprodução não autorizada pelo autor

Araujo, Christiane Bezerra de.

Novo peptídeo intracelular derivado da ciclina D2 induz morte celular / Christiane Bezerra de Araujo. -- São Paulo, 2014.

Orientador: Prof. Dr. Emer Suavinho Ferro.

Tese (Doutorado) - Universidade de São Paulo. Instituto de Ciências Biomédicas. Departamento de Anatomia. Área de concentração:

Ciências Morfofuncionais. Linha de pesquisa: Farmacologia molecular.

Versão do título para o inglês: A novel intracellular peptide derived from cyclin D2 induces cell death.

1. Peptídeos intracelulares 2. Peptídeo 5 3. Morte celular 4. Ciclo celular 5. Apoptose 6. Necrose I. Ferro, Prof. Dr. Emer Suavinho II. Universidade de São Paulo. Instituto de Ciências Biomédicas.

Programa de Pós-Graduação em Ciências Morfofuncionais III. Título. 
Candidato(a): $\quad$ Christiane Bezerra de Araujo.

Título da Tese: $\quad$ Novo peptídeo intracelular derivado da ciclina D2 induz morte celular.

Orientador(a): $\quad$ Prof. Dr. Emer Suavinho Ferro.

A Comissão Julgadora dos trabalhos de Defesa da Tese de Doutorado, em sessão pública realizada a considerou
( ) Aprovado(a)
( ) Reprovado(a)

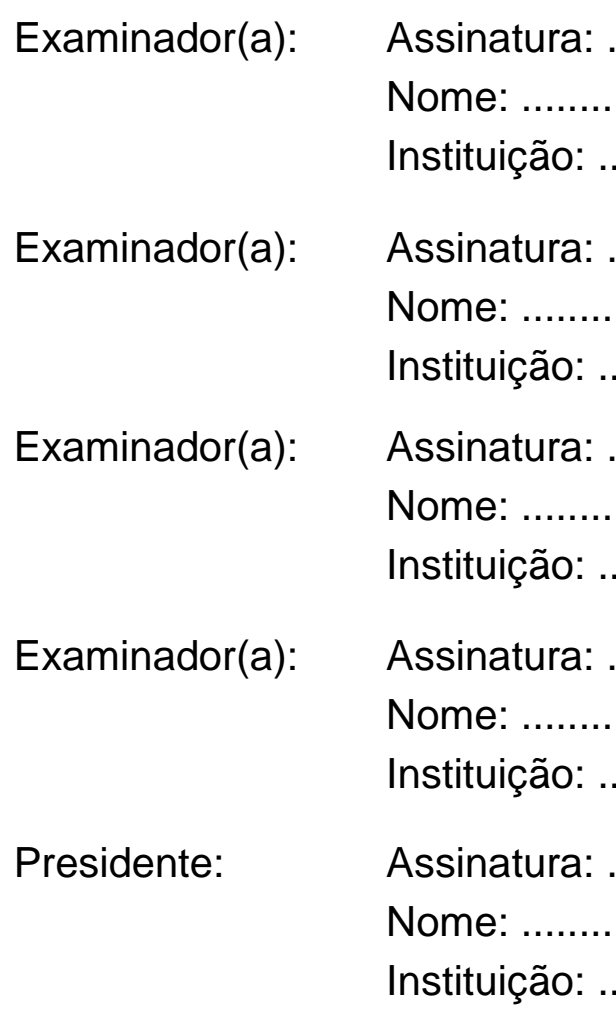




\section{CERTIFICADO DE ISENÇÃO}

Certificamos que o Protocolo CEP-ICB No $380 / 10$ referente ao projeto intitulado: "Peptídeos intracelulares no ciclo, proliferação e morte celular" sob a responsabilidade de Christiane Bezerra de Araújo, foi analisado na presente data pela CEUA - COMISSÃO DE ÉTICA NO USO DE ANIMAIS e pela CEPSH- COMISSÃO DE ÉTICA EM PESQUiSA COM SERES HUMANOS, tendo sido deliberado que o referido projeto não envolve manipulação animal ou humana que justifique uma aprovação quanto aos princípios éticos exigidos por ambas as Comissões.

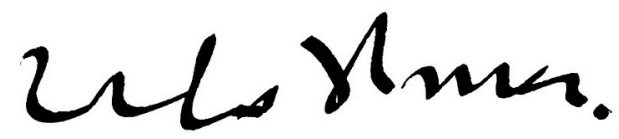

Prof. Dr. WOTHAN TAVARES DE LIMA Coordenador da CEUA - ICB/USP
São Paulo, 27 de abril de 2010.

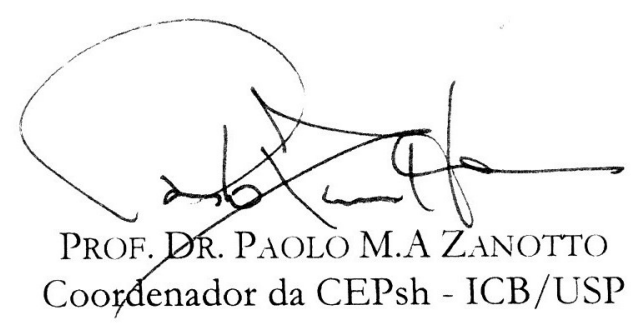


Aos meus pais Janeide e José por todo carinho e dedicação. Ao meu irmão Rafael e aos seletivos e confiáveis amigos. Obrigada! 


\section{AGRADECIMENTOS}

Ao Professor Doutor Emer Suavinho Ferro pela oportunidade e orientação durante estes quatro anos de doutorado.

Às agências CAPES (Coordenação de Aperfeiçoamento de Pessoal de Nível Superior), CNPq e à Pró-reitoria de pesquisa da USP (projeto NAPPS) pelo apoio financeiro.

À Professora Doutora Alison Colquhoun pela colaboração nos ensaios in vivo e pelas discussões científicas.

Ao Professor Doutor Fábio C. Gozzo, por gentilmente nos ceder o espectrômetro de massas para nossas análises; e à Professora Doutora Edna T. Kimura por permitir a utilização do citômetro de fluxo de seu laboratório.

A todos os integrantes e ex-integrantes do Laboratório de Comunicação Celular: Dr. Leandro Mantovani de Castro, Dr ${ }^{\mathrm{a}}$ Lílian C. Russo, $\mathrm{Dr}^{\mathrm{a}}$ Natália Mazini Ribeiro, Elisabete Rodrigues, Diogo Cavalcanti, Lilian Cruz e Cecília Café Mendes por todo o apoio, pelas discussões científicas e pela amizade sincera.

A Deus, pelo dom da vida.

Aos meus pais Janeide e José, pelo apoio, carinho e confiança.

Ao meu irmão Rafael pelo companheirismo e cumplicidade.

Aos meus poucos e bom amigos, que mesmo distantes fisicamente torcem e me apoiam com palavras de conforto e esperança. Em especial àquelas pessoas do meu convívio diário, os "lá de casa".

A todos que de alguma forma contribuíram para realização deste trabalho, principalmente aos que acreditaram que não seria possível. Obrigada! 


\section{RESUMO}

ARAUJO, C. B. Novo peptídeo intracelular derivado da ciclina D2 induz morte celular. 2014. 81 f. Tese (Doutorado em Ciências) - Instituto de Ciências Biomédicas, Universidade de São Paulo, São Paulo, 2014.

Peptídeos intracelulares são gerados a partir da degradação de proteínas no meio intracelular, e esse evento é realizado por um megacomplexo catalítico denominado proteassomo. Depois de serem clivados, esses fragmentos proteicos podem ser apresentados como antígenos via MHC I, podem ainda ser degradados em suas unidades funcionais, os aminoácidos, ou ainda, como nosso grupo tem demonstrado esses fragmentos de proteínas, contendo de 4 a 25 resíduos de aminoácidos, podem permanecer no meio intracelular e participar da regulação de eventos relacionados à sinalização celular. Neste trabalho, foi identificado um novo peptídeo intracelular denominado "peptídeo 5" (pep5). O pep5 foi identificado junto com outros 18 peptídeos por espectrometria de massas semi-quantitativa, tendo sido escolhido para análises funcionais posteriores por estar aumentado durante a fase $S$ do ciclo celular, quando comparado às outras fases e ao grupo de células assincrônicas. A liberação do pep5, a partir de sua proteína precursora ciclina D2, pode ocorrer por clivagem em sítios compatíveis com a ação do proteassomo. Para a realização de estudos funcionais, o pep5 foi sintetizado na forma natural (pep5) bem como acoplado covalentemente ao peptídeo penetrador de células (cpp; pep5-cpp), esse último para permitir sua internalização em modelos celulares e teciduais.

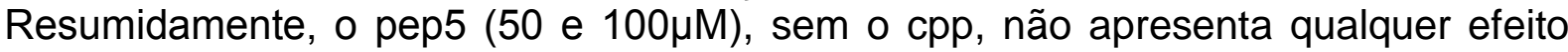

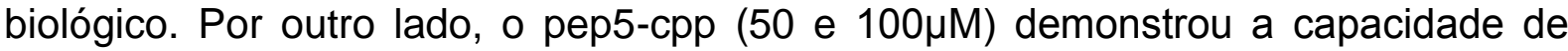
aumentar a porcentagem de morte em células HeLa e também em outras linhagens tumorais, dentre elas, linhagens de melanoma (SK MEL-28 e MEL 85), câncer de mama (SKRB), tumor de tiroide (TPC-1 e KTC-2) além de glioma de rato (células C6). O acoplamento do cpp ao $\mathrm{N}$ - ou C-terminal do pep5 muda sua potência (cpp-Nterminal < cpp-C-terminal), enquanto a remoção de apenas um resíduo de amino ácido do $\mathrm{N}$-terminal abole completamente sua ação indutora de morte celular, sugerindo sua especificidade estrutural. Além disso, quando o N-terminal do pep5cpp é acetilado, há uma redução da eficácia deste fragmento de ciclina em promover a morte de linhagens celulares em cultura, enquanto que substituições de Leu por Ala abolem totalmente a atividade do pep5-cpp. In vivo, o pep5-cpp reduziu aproximadamente $50 \%$ o volume do glioblastoma C6 em cérebros de ratos Wistar. O pep5-cpp aumentou a atividade das caspases 9, 3/7, mas não da caspase 8, e regulou a fosforilação de MAPKs e alguns de seus substratos específicos como Akt2. A morte celular induzida pelo pep5-cpp foi caracterizada ocorrendo tanto por apoptose quanto por necrose. Corroborando esses resultados, inibidores seletivos diminuíram a indução de morte celular mediada pelo pep5-cpp. Portanto, demonstramos nesse trabalho que os níveis relativos de peptídeos intracelulares variam durante fases específicas do ciclo celular. Um desses peptídeos, o pep5-cpp, foi caracterizado aqui como indutor de morte celular, tanto em modelos in vitro como in vivo.

Palavras-chave: Peptídeos intracelulares. Ciclo celular. Apoptose. Necrose. Morte celular. 


\begin{abstract}
ARAUJO, C. B. A novel intracellular peptide derived from cyclin D2 induces cell death. 2014. 81 p. Ph. D. thesis (Science) - Instituto de Ciências Biomédicas, Universidade de São Paulo, São Paulo, 2014.

Intracellular peptides are generated by degradation of intracellular proteins and this event is realized by a catalytic megacomplex called proteasome. After being cleaved, protein fragments can be presented via $\mathrm{MHC}$ I as antigens, can be further degraded into their functional units, the amino acids, or as our group has showed, these protein fragments containing from 4 to 25 residues may remain in the intracellular environment and participate in the regulation of events related to the cell signaling. In this work, a new intracellular peptide called "peptide 5" (pep5) was identified. The pep5 was identified with other 18 peptides by mass spectrometry, and it was chosen for further functional analysis to be increased during the $S$ phase of the cell cycle, when compared to the other phases and the asynchronous cells. The release of pep5 from its precursor the cyclin D2 protein can occur by cleavage in compatible sites with the action of the proteasome. To perform functional studies, pep5 was synthesized in the natural form (pep5) or covalently bound to the cell penetrating peptide (pep5-cpp), to allow its internalization in cell and tissue models. Briefly, the pep5 (50 and $100 \mu \mathrm{M}$ ), without cpp, showed no biological effect. On the other hand, pep5-cpp (50 and $100 \mu \mathrm{M})$ demonstrated the ability to increase the percentage of cell death in HeLa cells and also in other tumor cell lines, as melanoma (MEL-28 and SK MEL 85), breast cancer (SKRB), tumor thyroid (TPC-1 and KTC-2) as well as rat glioma (C6 cells). The coupling of the cpp in N- or C-terminal of the pep5 changes its power (cpp- N-terminal < cpp C- terminal), while removing only one amino acid of the $\mathrm{N}$-terminus completely abolishes its action in the cell death, suggesting a structurerelated action. Also, when the N-terminal of the pep5-cpp is acetylated there is a reduction in the percentage of cell death in HeLa cells, whereas substitutions Leu-Ala completely abolish the activity of pep5-cpp. In vivo, the pep5-cpp reduced approximately $50 \%$ the volume of rat C6 glioblastoma. The pep5-cpp increased the activity of caspases $9,3 / 7$, but not caspase 8 , and regulated the phosphorylation of MAPKs or their specific substrates as Akt2. Pep5-cpp induced cell death was either by apoptosis and necrosis. Corroborating these results, selective inhibitors for both processes decreased the cell death. Therefore, we have shown here that intracellular peptides may act as pharmacological cell death inducers.
\end{abstract}

Keywords: Intracellular Peptides. Cell cycle. Apoptosis. Necrosis. Cell death. 


\section{LISTA DE ILUSTRAÇÕES}

Figura 1. Regulação do ciclo celular pelas E3 ubiquitina ligases............................. 22

Figura 2. Efeito do excesso de timidina na progressão do ciclo celular.................... 30

Figura 3. Esquema de marcação isotópica dos extratos peptídicos isolados nas diferentes fases do ciclo celular.

Figura 4. Sincronização de células HeLa usando timidina $2 \mathrm{mM}$.

Figura 5. Espectros de MS ilustrando as análises semi-quantitativas de peptídeos isolados a partir de extratos de células HeLa sincronizadas (S, G2/M, e G1) ou assincrônicas.

Figura 6. Efeito de peptídeos intracelulares no ciclo celular e viabilidade de células HeLa

Figura 7. Efeito de pep5-cpp em células HeLa.

Figura 8. Efeito de modificações na sequência original do pep5-cpp.

Figura 9. Efeito do pep5-cpp em diferentes linhagens celulares.

Figura 10. Efeitos in vivo do $\Delta N$-pep5-cpp ou pep5-cpp em glioma de rato (C6)........

Figura 11. Análise do mecanismo de morte celular induzido pelo pep5cpp.

Figura 12. Ensaio de caspases ativas após tratamento com o pep5-cpp.

Figura 13. Efeito do pep5-cpp na fosforilação de MAPKs específicas ou seus substratos.

Figura 14. Inibidores de morte celular diminuem o efeito do pep5-cpp

Figura 15. Atividade proteolítica do proteassomo em células HeLa tratadas ou não com o pep5-cpp.

Figura 16. Alinhamento das sequências de ciclinas $D$

Figura 17. Possíveis sítios de clivagem proteassomal para formação do pep5. 


\section{LISTA DE TABELAS}

Tabela 1. Proteínas precursoras e peptídeos identificados em células HeLa durante a progressão do ciclo celular......

Tabela 2. Porcentagem de morte celular induzida pelo pep5-cpp em diferentes tipos celulares. 


\section{LISTA DE ABREVIATURAS E SIGLAS}

Akt2 - proteína quinase B ( V-akt murine thymoma viral oncogene homolog 2)

$\mathrm{CaCl}_{2}$ - cloreto de cálcio

CDKs - quinases dependentes de ciclinas

CKIs - inibidores de quinases dependentes de ciclinas (cyclin-dependent kinase inhibitors)

CPP - peptídeo penetrador de células (cell penetrating peptide)

D0-TMAB - 4-trimetil-amônio-butiril sem átomos de deutério

D12-TMAB - 4-trimetil-amônio-butiril com 12 átomos de deutério

D3-TMAB - 4-trimetil-amônio-butiril com 3 átomos de deutério

D9-TMAB - 4-trimetil-amônio-butiril com 9 átomos de deutério

DMEM - meio de cultura (Dulbecco's modified eagle medium)

DNA - ácido desoxirribonucleico (deoxyribonucleic acid)

EP24.15 - thimet-oligopeptidase (EC 3.4.24.15)

ERKs - quinases reguladas por sinal extracelular (extracellular signal-regulated)

G1 - gap 1

G2 - gap 2

GPCRs - receptores acoplados a proteínas G

$\mathrm{HCl}$ - ácido clorídrico

HE - hematoxilina-eosina

HSP27 - proteína de choque térmico (heat shock protein)

$\mathrm{Hz}-$ hertz

JNK/SAPK - c-jun N-terminal quinases ativadas por estresse (c-jun $N$-terminal or stressactivated protein kinases)

$\mathrm{KCl}$ - cloreto de potássio

LC/MS/MS - cromatografia líquida acoplada à espectrometria de massas

$M-$ mitose 
MAPKs - proteínas quinases ativadas por mitógenos (mitogen-activated protein kinase)

$\mathrm{MgCl}_{2}$ - cloreto de magnésio

MHC I - complexo de histocompatibilidade de classe I

MPF - fator promotor da mitose (mitosis promoting factor)

MS - espectrometria de massas (mass spectrometry)

$\mathrm{Na}_{2} \mathrm{HPO}_{4}$ - fosfato de sódio dibásico

$\mathrm{NaCl}$ - cloreto de sódio

$\mathrm{NaH}_{2} \mathrm{PO}_{4}$ - fosfato monobásico de sódio

NP-40 - nonidete P40

OV - overnight - incubação por período entre $8-14$ horas

p70 S6 kinase - quinase serina/treonina (serine/threonine kinase)

PB - tampão fosfato

PBS - tampão salina fosfato

PCNA - antígeno nuclear da proliferação celular.

$\mathrm{PI}$ - iodeto de propídeo

PKC - proteína quinase c

RIPK1-RIPK3 - complexo proteína quinase 1 interagindo com receptor (receptorinteracting protein kinase 1 complex)

RNAse - ribonuclease

RPM - rotações por minuto

RPMI 1640 - meio de cultura (Roswell Park Memorial Institute)

S - síntese

SFB - soro fetal bovino

TMAB - 4-trimetil-amônio-butiril

TMAB-NHS - cloreto de [3-(2,5-dioxo-pirrolidina-1-iloxicarbonil)-propil] trimetilamônio UPS - sistema ubiquitina proteassomo (ubiquitin proteasome system) 


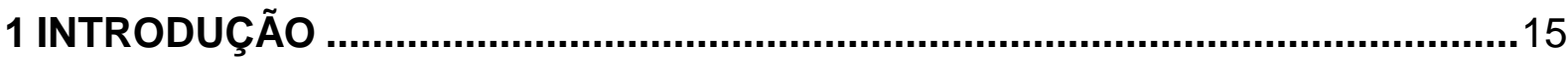

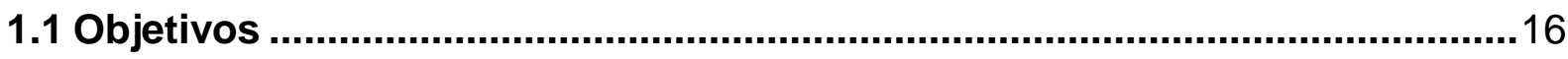

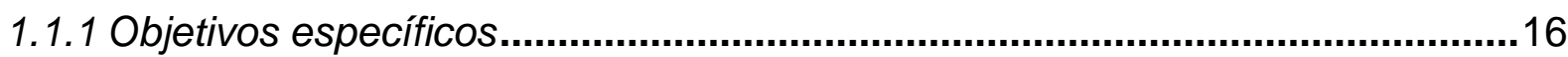

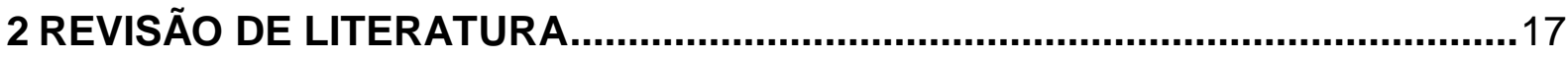

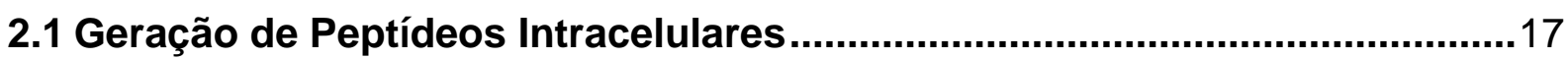

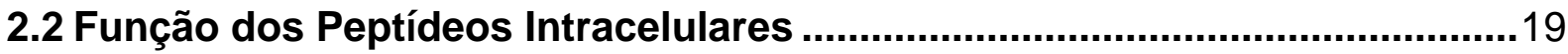

2.3 Controle do Ciclo Celular Mediado por Proteólise Proteassomal ..................20

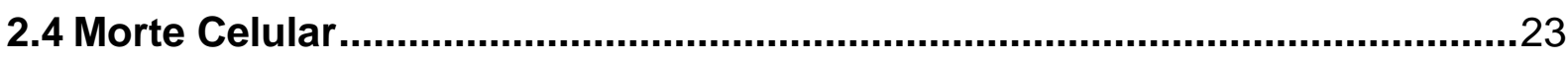

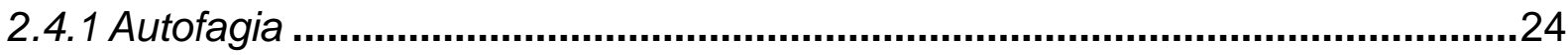

2.4.2 Apoptose

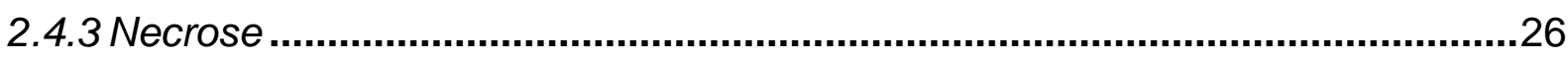

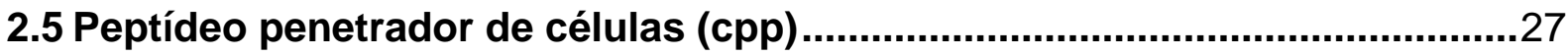

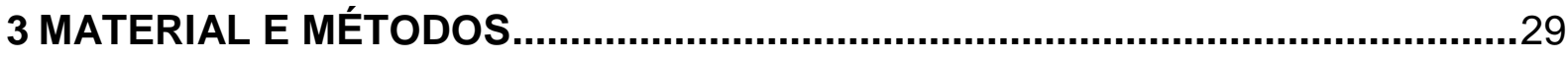

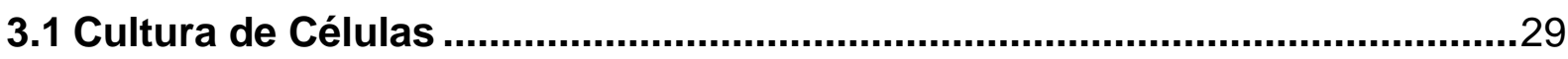

3.2 Sincronização Celular pelo Método de Bloqueio Duplo com Timidina.........29

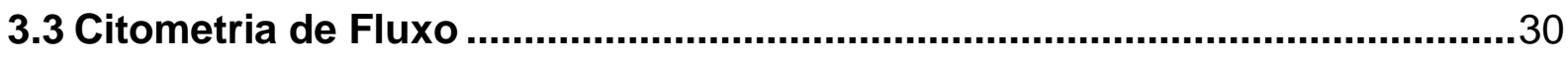

3.4 Extração e Quantificação dos Peptídeos em Diferentes Fases do Ciclo

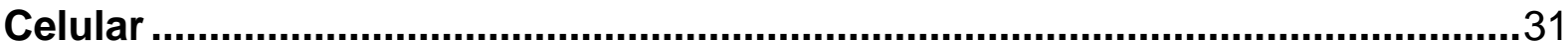

3.5 Marcação Isotópica e Espectrometria de Massas para Identificação de Peptídeos ao Longo do Ciclo Celular...................................................................

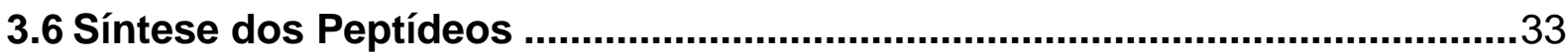

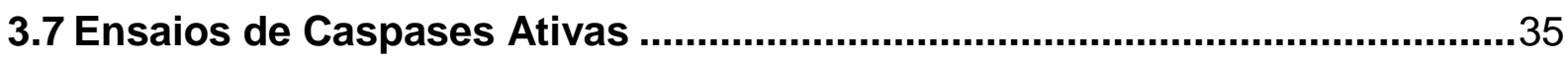

3.8 Efeito do pep5 na Fosforilação de MAP Quinases Específicas ou de Seus

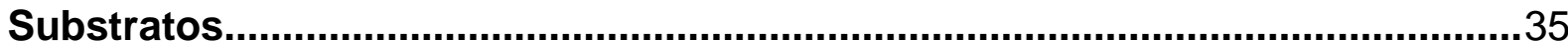

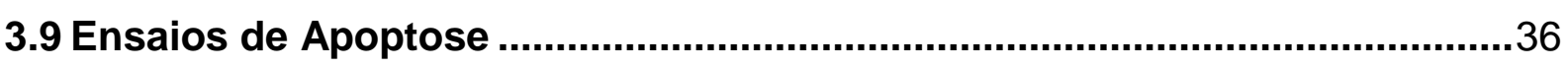

3.10 Ação do pep5-cpp na Presença de Inibidores de Morte Celular

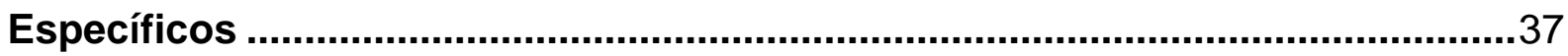

3.11 Ação Antitumoral in vivo do pep5-cpp Usando o Modelo de Glioblastoma Induzido pela Injeção de Células C6 (glioma de rato) Intracerebral ....................37

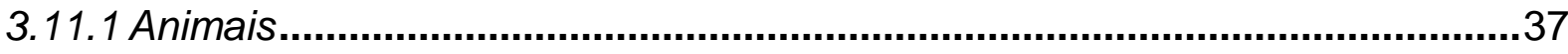


3.11.2 Geração de Tumor Experimental em Cérebro de Ratos Usando Células de

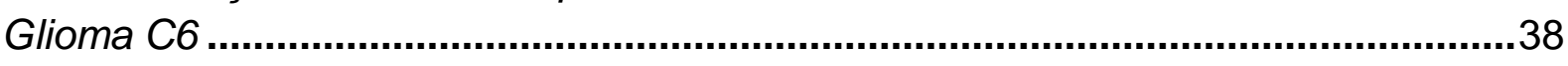

3.11.3 Infusão Intratumoral de Peptídeos Utilizando Microbombas ALZET................38

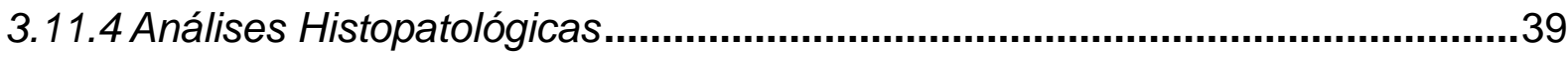

3.12 Efeito do Pep5 na Atividade Quimotripsina do Proteassomo ......................39

3.13 Formas de Análises dos Resultados ............................................................

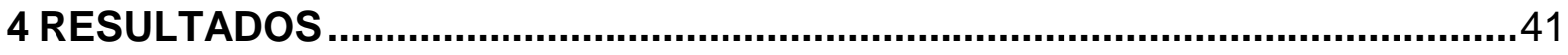

4.1 Sincronização Celular por Excesso de Timidina ...........................................41

4.2 Extração e Quantificação dos Peptídeos ao Longo do Ciclo Celular ...........41

4.3 Efeito de Peptídeos Intracelulares Identificados ao Longo do Ciclo Celular

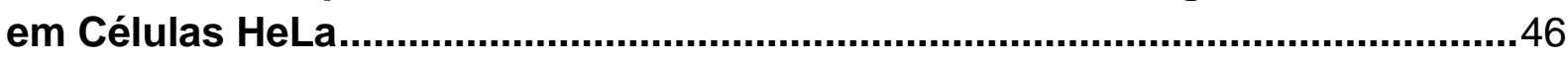

4.4 Efeito do pep5-cpp em Outras Linhagens Celulares.......................................50

4.5 Teste in vivo do pep5-cpp em Glioblastoma de Rato ......................................53

4.6 Mecanismos de Morte Celular Induzidos pelo pep5-cpp …...........................55

4.7 Ação do pep5-cpp na Atividade Quimotripsina do Proteassomo .................60

5 DISCUSSÃO

6 CONCLUSÃO

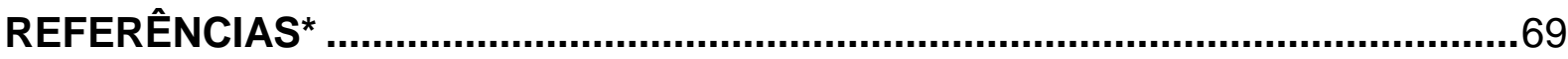




\section{INTRODUÇÃO}

A especificidade e a robustez do módulo de controle do ciclo celular são garantidas por um equilíbrio fino entre múltiplas reações sinérgicas e antagônicas, cuja organização ainda é obscura (BJORKLUND et al., 2006). No plano bioquímico, três mecanismos de regulação serão sempre importantes e recorrentes: a) rápida indução da transcrição de genes codificadores de proteínas altamente instáveis; b) ativação/desativação funcional de proteínas muito estáveis, através de efeitos alostéricos e modificações covalentes; c) degradação específica de proteínas através da proteólise mediada pelo sistema ubiquitina-proteassomo (UPS) (DOMIAN; QUON; SHAPIRO, 1997).

Considerando a degradação de proteínas, após serem sintetizadas essas sofrem alterações estruturais que podem incorrer em alterações de suas funções naturais, e em células vivas precisam ser continuamente renovadas por serem responsáveis por processos decisivos como regulação da divisão celular, expressão gênica, entre outros (DOMIAN; QUON; SHAPIRO, 1997; LEWIS et al., 2000). Aquelas presentes no citoplasma e núcleo são degradadas por uma série de mecanismos diferentes (SOUGHAYER et al., 2004), entre esses aquele que seleciona para a degradação marcando covalentemente com poli-ubiquitinas (BAI et al., 1996; GOLDBERG, 2003; KOPELMAN, 2000; PARENTEAU et al., 2005). Uma proteína poli-ubiquitinada é degradada em peptídeos curtos (2-20 aminoácidos) em um processo dependente de ATP e catalisado por um complexo protéico de 2,4 Mega Daltons (MDa), contendo múltiplas subunidades, denominado proteassomo 26S (GOLDBERG, 2003; ORLOWSKI, 1990; SOUGHAYER et al., 2004). Acredita-se que estes peptídeos gerados pelo proteassoma sejam rapidamente hidrolisados em aminoácidos que são utilizados no processo de síntese de novas proteínas. Mas já se sabe que em células de mamíferos alguns peptídeos intracelulares escapam da degradação completa para exercerem a função de antígenos no sistema imune associados ao complexo de histocompatibilidade (MHC) classe I (KIM et al., 2003; SARIC et al., 2001).

De fato, além da conhecida ação mediada por receptores localizados na membrana plasmática, e funções antigênicas, alguns peptídeos também estão envolvidos em processos intracelulares. Sabe-se que peptídeos derivados de proteínas citosólicas, nucleares e mitocondriais existem em número bastante 
significante em tecidos e células animais (BERTI et al., 2009; CASTRO et al., 2010; FRICKER et al., 2012). Esses peptídeos foram caracterizados como os substratos e produtos naturais da thimet-oligopeptidase (EC 3.4.24.15; EP24.15) (BERTI et al., 2009) e capazes de alterar a transdução de sinal iniciada por agonistas de receptores acoplados a proteínas G (GPCRs) como a angiotensina II ou isoproterenol (CUNHA et al., 2008). No conjunto, esses e outros resultados sugerem a presença de um novo grupo de moléculas bioativas endógenas (BERTI et al., 2009; CUNHA et al., 2008; GOMES et al., 2009; HEIMANN et al., 2007), que nosso grupo denominou "peptídeos intracelulares" (FERRO; HYSLOP; CAMARGO, 2004).

\subsection{Objetivos}

O objetivo deste trabalho foi investigar peptídeos intracelulares em processos celulares vitais como a proliferação e morte celular, a saber:

\subsubsection{Objetivos específicos}

$\checkmark \quad$ Determinar a composição peptídica (peptidoma) de células HeLa em diferentes estágios do ciclo celular, utilizando técnicas semi-quantitativas de marcação isotópica e espectrometria de massas, como anteriormente descrito (BEREZNIUK et al., 2010; BERTI et al., 2009);

Analisar o efeito de peptídeos intracelulares específicos no ciclo celular, bem como nos processos de proliferação e morte celular. 


\section{REVISÃO DE LITERATURA}

\subsection{Geração de Peptídeos Intracelulares}

O UPS é responsável pela manutenção da homeostase proteica em células, e dentre suas funções essenciais está o envolvimento com a biologia do câncer e sistema imunológico. O proteassomo é responsável pela clivagem intracelular, extralisossomal, de proteínas antigênicas e pela geração de peptídeos apresentados pelo complexo de histocompatibilidade de classe I (MHC-I). Estes fragmentos de proteínas gerados pelo proteassomo podem ainda ser clivados dentro do retículo endoplasmático, por aminopeptidases residentes, para produzir um $\mathrm{N}$ terminal correto que irá interagir com o MHC-I (PAZ et al., 1999; ROCK; GOLDBERG, 1999). $\mathrm{Na}$ biologia do câncer o UPS é importante para progressão do ciclo celular, por exemplo, levando a degradação de ciclinas (HERSHKO, 2005). A inibição do proteassomo é utilizada na clínica para o tratamento de certos tipos de câncer, e tem sido a ferramenta escolhida para o tratamento de mieloma múltiplo recidivo (GOLDBERG, 2012).

O proteassomo de mamíferos é um megacomplexo catalítico de aproximadamente 2,4 $\mathrm{MDa}$, sendo formado pela partícula regulatória $19 \mathrm{~S}$ e pelo core catalítico 20S (ADAMS, 2003). A partícula regulatória consiste de aproximadamente 19 subunidades, sendo o complexo inteiro de $1 \mathrm{MDa}$. Nove destas subunidades se juntam para formar a "tampa", enquanto que as outras 10, sendo seis ATPases, formam a base (GROLL et al., 1997; GROLL; HUBER, 2005). A partícula $19 S$ é responsável pelo reconhecimento, desdobramento e encaminhamento de substratos poliubiquitinados para o 20S. Já a partícula catalítica é formada por dois anéis heptaméricos do tipo alfa ( $\alpha$ ) e dois anéis, também heptaméricos, do tipo beta ( $\beta$ ). Cada anel é formado por sete subunidades, sendo a subunidade beta-1 responsável pela clivagem de ligações peptídicas em resíduos ácidos, a subunidade beta-2 cliva após resíduos básicos e a subunidade beta-5 que cliva após resíduos hidrofóbicos (GROLL et al., 2002; HEINK et al., 2005; KLOETZEL, 2001; NAVON; CIECHANOVER, 2009).

Existem ainda outras formas do proteassomo, como o core catalítico $20 \mathrm{~S}$ sozinho e com subunidades ativadoras ligadas a qualquer uma ou ambas as extremidades do domínio 20 S (STADTMUELLER; HILL, 2011). Estes ativadores do 
proteassomo 20S, incluem as subunidades $11 \mathrm{~S}$ (também chamada de PA28) e a PA200, além das subunidades reguladoras $19 S$ mencionadas. A subunidade 195 é essencial para o desdobramento e degradação de proteínas contendo cadeias de poli-ubiquitinas conjugadas. Em contraste, as subunidades $11 \mathrm{~S}$ e as subunidades PA200 aumentam grandemente a capacidade do proteassomo $20 \mathrm{~S}$ de clivar peptídeos diretamente (DICK et al., 1996; DUBIEL et al., 1992; MA; SLAUGHTER; DEMARTINO, 1992; STADTMUELLER; HILL, 2011; USTRELL et al., 2002). Além da clivagem de peptídeos intracelulares, o proteassomo 20 S sozinho ou conjugado com as subunidades $11 \mathrm{~S}$ pode clivar algumas proteínas não ubiquitinadas (CHEN et al., 2007; LI et al., 2006; SHEAFF et al., 2000; SUZUKI et al., 2009).

A degradação de proteínas pelo proteassomo gera peptídeos intermediários contendo de 2 a 21 resíduos de aminoácidos (KISSELEV; AKOPIAN; GOLDBERG, 1998; KISSELEV et al., 1999), o que sugere que as células estão continuamente produzindo uma grande quantidade de peptídeos com 2-21 aminoácidos. Entretanto, de acordo com a literatura, somente um peptídeo proveniente de cada proteína presente na célula escaparia da degradação proteolítica pós proteassomo para ser apresentado como antígeno via MHC-I (GEIER et al., 1999; RAMMENSEE, 2002). Assim, acredita-se que praticamente a proteína inteira seja reciclada em aminoácidos dentro das células.

Adicionalmente, em fungos, células de mamíferos e moscas, as consequências provocadas pela inibição do proteassomo são resgatadas através de suplementação com aminoácidos, revelando a importância do sistema proteassomal na reciclagem dos aminoácidos para uma nova síntese de proteínas (SURAWEERA et al., 2012). Outros trabalhos têm sugerido que peptídeos produzidos pelo proteassomo têm uma meia-vida de apenas alguns segundos (BENINGA; ROCK; GOLDBERG, 1998; REITS et al., 2003; REITS et al., 2004).

Em circunstâncias específicas o UPS pode realizar uma proteólise limitada tal como na geração do complexo dimérico de transcrição NFKB ativo (KRAVTSOVAIVANTSIV; COHEN; CIECHANOVER, 2009). Portanto, está claro que o proteassomo pode realizar ambas as proteólises extensiva e limitada dependendo da proteína substrato. Em nosso laboratório, temos demonstrado que o proteassomo poderia desempenhar um papel mais amplo na proteólise limitada do que anteriormente antecipado, gerando os peptídeos intracelulares (FERRO; HYSLOP; CAMARGO, 2004; FRICKER et al., 2012; GELMAN et al., 2013). Estes achados foram baseados 
em um bem estabelecido conceito de que peptídeos racionalmente desenhados, estruturalmente similares àqueles produzidos pelo proteassomo, podem regular a localização espacial de proteínas no meio intracelular, e assim controlar a transdução de sinal das células (BURNS-HAMURO et al., 2003; CHURCHILL; QVIT; MOCHLY-ROSEN, 2009). Assim, peptídeos intracelulares naturalmente gerados pelo proteassomo constituem ainda um mecanismo pobremente entendido, pelo qual células podem aumentar enormemente a complexidade da rede de interações proteícas e consequentemente de suas funções (FERRO; HYSLOP; CAMARGO, 2004).

\subsection{Função dos Peptídeos Intracelulares}

A hemopressina, o primeiro peptídeo intracelular identificado utilizando o racional discutido acima, demonstrou ação como agonista inverso de receptores canabinóides e foi capaz de regular a ingestão de alimentos em modelos animais, (DODD et al., 2010; GELMAN et al., 2013; GOMES et al., 2009; HEIMANN et al., 2007; RIOLI et al., 2003). Enquanto as hemopressinas naturais presentes no cérebro são secretadas e podem desempenhar uma importante função como endocanabinóides.

Outros trabalhos também demonstraram que peptídeos intracelulares podem funcionar como moduladores da transdução de sinal apenas quando presentes no meio intracelular. Estes últimos peptídeos, estruturalmente relacionados a produtos do proteassomo, foram identificados por espectrometria de massas, quimicamente sintetizados e reintroduzidos em células em cultura. Alguns deles foram capazes de modular a transdução de sinal mediada por receptores de angiotensina II (AT1) e beta-adrenérgicos (Beta-2) (CUNHA et al., 2008). Estes peptídeos foram testados por cromatografia de afinidade e como resultado se ligaram a uma gama específica de proteínas que participam do tráfego vesicular (CUNHA et al., 2008). Além da atividade do proteassomo como produtor destes peptídeos naturais, a thimet oligopeptidase (EC 3.4.24.15; EP24.15), uma peptidase intracelular que degrada pequenos peptídeos ( 5-17 resíduos de aminoácidos), também demonstrou participação no metabolismo de peptídeos intracelulares (BERTI et al., 2009). Manipulando a atividade intracelular da EP24.15 por superexpressão da enzima ou inibindo sua atividade por siRNA, foi possível observar alteração da transdução de 
sinal via receptores acoplados à proteína G (GPCRs) em células HEK293 e CHO-S (CUNHA et al., 2008; RUSSO et al., 2012). Estes dados sugerem uma desconhecida conexão entre o metabolismo de peptídeos intracelulares e a sinalização celular. Outras vias de transdução de sinal poderiam também estar relacionadas à atividade de certos peptídeos intracelulares, como foi observado com dois peptídeos, de sequências similares, encontrados no tecido adiposo de ratos Wistar, os quais demonstraram se ligar à proteínas específicas além de facilitar a captação de glicose induzida por insulina em células adiposas 3T3-L1 em cultura (BERTI et al., 2012).

Embora ainda não tenha sido demonstrado que peptídeos intracelulares podem modular interações proteína-proteína in vivo, utilizando ressonância plasmônica de superfície (RPS) foi possível observar, in vitro, que diversos peptídeos naturais em concentrações de 1-50 $\mu \mathrm{M}$ foram capazes de modular a interação da calmodulina e 14-3-3ع com proteínas provenientes de cérebro de camundongos ou com a EP24.15 recombinante. Um destes peptídeos, o VFDVELL (VFD-7), que é produto do proteassomo (BERTI et al., 2009) aumenta a concentração de cálcio citosólico de uma maneira dose-dependente, contudo isso ocorre somente quando este peptídeo é reintroduzido no meio intracelular (RUSSO et al., 2012).

\subsection{Controle do Ciclo Celular Mediado por Proteólise Proteassomal}

O ciclo de divisão de uma célula consiste em basicamente dois processos, a duplicação do DNA e a segregação dos cromossomos para os polos opostos das duas células nascentes. Esta divisão celular é subdivida em duas grandes etapas: a mitose $(M)$ onde ocorre a fragmentação da membrana nuclear, duplicação e migração dos cromossomos e a separação das duas células filhas; e a interfase, que é composta por duas fases de gap, G1 e G2, e uma fase de síntese de DNA, a fase S (NORBURY; NURSE, 1992). A regulação da transição de fases do ciclo celular é realizada por diversas proteínas, sendo as quinases dependentes de ciclinas (CDKs), proteínas-chave neste tipo de controle. Estas proteínas pertencem à família das serina/treonina quinases e são ativadas em específicos pontos de transição ao longo do ciclo celular (MALUMBRES; BARBACID, 2005; MORGAN, 1997). As CDKs são ativadas por partículas regulatórias denominadas ciclinas. As ciclinas são pequenas proteínas que são produzidas e degradadas ao longo de cada fase do ciclo celular, e ao se ligarem aos seus respectivos parceiros, formando o complexo 
ciclina-CDK, são responsáveis pela regulação de diversos outros tipos de fatores dentro da célula. Em mamíferos existem quatro tipos principais de ciclinas: $A, B, D$ e E. As ciclinas do tipo $B$ são citoplasmáticas, enquanto que as ciclinas do tipo $A, E$ e D são nucleares (OHTSUBO et al., 1995; PINES; HUNTER, 1994; SHERR, 1993). As ciclinas do tipo D (D1, D2 e D3) são expressas em uma variedade de tecidos e tipos celulares, sendo que a ciclina D1 é ubiquamente expressa na maioria das células (WACLAW; CHATOT, 2004).

A transição de fase da metáfase para a anáfase, no fim da mitose, é regulada pela degradação de ciclinas que, por sua vez, leva a inibição do fator promotor da mitose (MPF; quinase específica da fase M), fazendo com que a célula entre mais uma vez na interfase. A degradação da ciclina, específica da fase $M$, para durante 0 início de G1, e com o decorrer do tempo há novamente o acúmulo desta ciclina faseespecífica, o que posteriormente irá levar a mais uma ativação do MPF e a entrada mais uma vez da célula em mitose (EVANS et al., 1983; SOLOMON et al., 1990). Isso ocorre na transição de todas as fases do ciclo celular de uma célula, em que ciclinas são produzidas, acumuladas, ativam suas CDKs específicas e após a atividade deste complexo, as ciclinas são marcadas para degradação pelo proteassomo (GLOTZER; MURRAY; KIRSCHNER, 1991).

Proteínas destinadas à degradação pelo proteassomo são, geralmente, poliubiquitinadas. A ubiquitina é uma proteína de aproximadamente $8 \mathrm{kDa}$ e é adicionada aos substratos por três componentes enzimáticos. A enzima E1 é responsável pela ativação da ubiquitina, a E2 é chamada de enzima carreadora ou conjugadora, enquanto que a E3 é a proteína ligase responsável por reconhecer e catalisar a transferência da ubiquitina ativada para as proteínas que serão degradadas (GLICKMAN; CIECHANOVER, 2002; LECKER; GOLDBERG; MITCH, 2006). Durante o ciclo celular dois complexos são responsáveis pela poliubiquitinação dos substratos, os complexos SCF (proteínas Skp1/culina/F-box) e o APC/C (complexo promotor da anáfase) (HARPER; BURTON; SOLOMON, 2002; PETERS, 2002; VODERMAIER, 2004). 
Figura 1. Regulação do ciclo celular pelas E3 ubiquitina ligases.

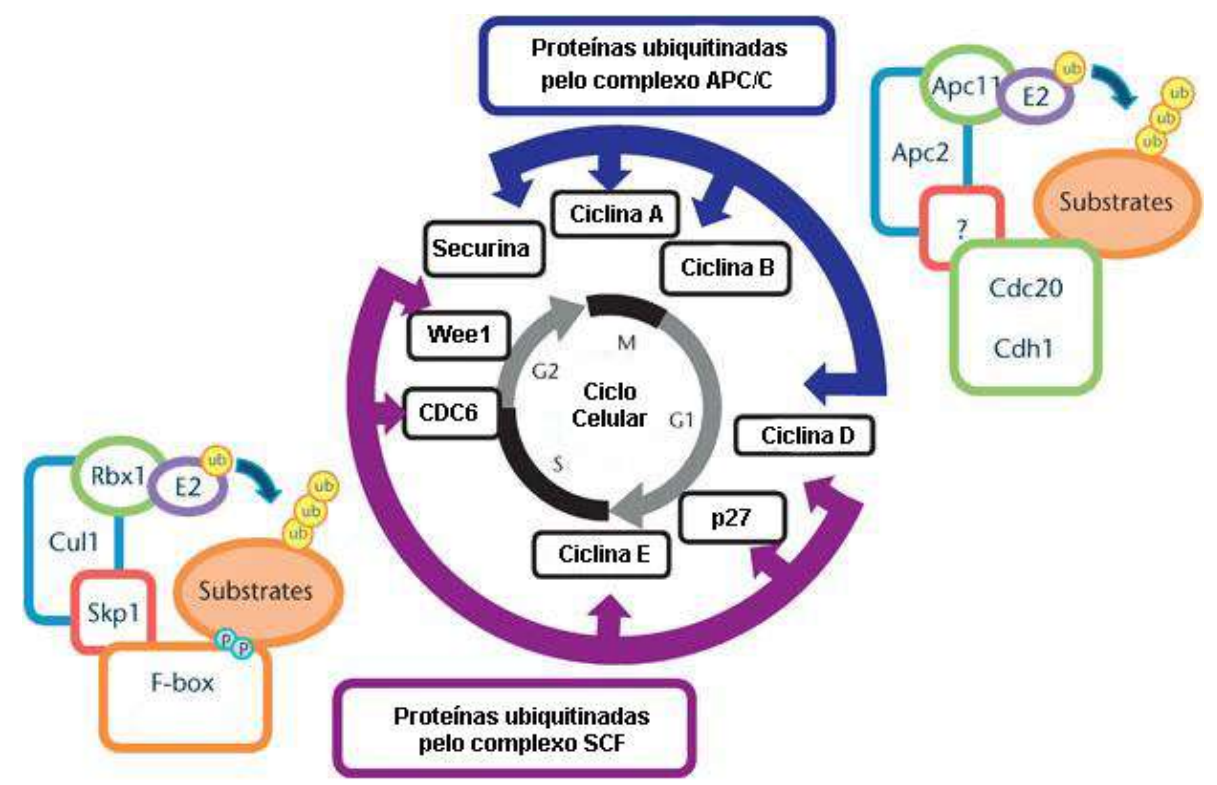

O complexo SCF é responsável pela ubiquitinação de proteínas atuantes no final da fase G1 ao início da fase $M$, enquanto que o complexo APC/C marca proteínas para degradação da mitose até o início de G1 (SHAlK et al., 2012).

Um exemplo de controle do ciclo celular através da proteólise proteassomal é a degradação da ciclina D1. Os níveis de ciclina D1 aumentam durante o início da fase G1 e se mantêm altos até a transição de G1/S, quando há um declínio na quantidade desta proteína (ALAO, 2007). A degradação da ciclina é essencial para que as células entrem na fase de síntese do DNA, pois foi demonstrado que a superexpressão de ciclina D1 em fibroblastos impede a entrada das células na fase S (PAGANO et al., 1994). E esta inibição da síntese de DNA pode estar relacionada com a capacidade da ciclina D1 de se ligar ao antígeno nuclear da proliferação celular (PCNA) e cdk2 e assim acabar por não permitir que a célula inicie a duplicação do material genético (FUKAMI-KOBAYASHI; MITSUI, 1999). Outros trabalhos demostraram que a fosforilação da ciclina D1 pela GSK3 $\beta$ no resíduo de treonina 286 (T286) induz à translocação da ciclina para o citoplasma, seguida de uma rápida degradação desta proteína pela via do proteassomo (DIEHL et al., 1998; DIEHL; ZINDY; SHERR, 1997). Em Drosophila, foi observado que apesar da presença constante de ciclinas e Cdk1, a degradação de ciclinas específicas parece ser essencial para que as células embrionárias saiam da mitose (SU et al., 1998). Já em Saccharomyces cerevisiae a proteólise da ciclina Cln3 também é ubiquitina 
dependente sendo importante para a regulação da fase $G 1$ do ciclo celular (YAGLOM et al., 1995).

O ciclo celular também é controlado pelas proteínas inibidoras de CDKs, também conhecidas como CKIs (SHERR; ROBERTS, 1999). A degradação destas CKls (p21, p27 e p53) constitui um passo importante para a transição de fases durante a divisão de uma célula. Em $C$. elegans, uma ubiquitina ligase (E3 ligase CRL2) é responsável por marcar a p21 citoplasmática para degradação, além de estimular a degradação proteassomal da CKI-1 quando expressa em células humanas (STAROSTINA et al., 2010). Já a p53 regula uma diversidade de eventos celulares como apoptose, senescência e bloqueio do ciclo celular. Os níveis celulares de p53 são regulados pela MDM2, uma E3 ubiquitina ligase que marca esta CKI para degradação via proteassomo (HAUPT et al., 1997; KUBBUTAT; JONES; VOUSDEN, 1997; PRIVES; HALL, 1999). Sendo assim, peptídeos intracelulares podem ser gerados a partir da degradação de diversas proteínas essenciais para o controle do ciclo celular, e por sua vez, alguns destes peptídeos poderiam estar envolvidos na regulação do ciclo celular ou no controle de eventos como a morte celular.

\subsection{Morte Celular}

Para os organismos multicelulares, a morte desempenha um papel tão importante quanto à decisão de sobrevivência. A morte celular programada, por exemplo, é importante durante a embriogênese eliminando células desnecessárias. Em organismos adultos a morte celular é indispensável para a homeostase, eliminando células velhas ou danificadas, como ocorre nos epitélios de revestimento do nosso corpo (FUCHS; STELLER, 2011; HARDY; HANDYSIDE; WINSTON, 1989; $\mathrm{LI}$ et al., 2010). Falhas na eliminação destas células danificadas podem levar ao aparecimento de enfermidades como o câncer. Existem três tipos básicos de classificação de mortes celulares: autofagia, apoptose e necrose (KROEMER et al., 2005). 


\subsubsection{Autofagia}

A autofagia é um tipo de morte celular morfologicamente definida pela ausência de condensação cromossômica acompanhada pela massiva vacuolização do citoplasma (KROEMER et al., 2005). A autofagia ocorre em uma extensa variedade de organismos eucarióticos e em diferentes tipos celulares durante a carência de fatores de crescimento, a remodelação celular e tecidual, aumento da temperatura e a morte celular (GORDON; KOVACS; SEGLEN, 1987; LEVINE; KLIONSKY, 2004). Contudo, a importancia da autofagia durante o desenvolvimento tem sido alvo de estudos.

Diversos genes são ativados para que ocorra este tipo de morte celular em diferentes organismos. Em D. melanogaster, mutações do gene de autofagia CG10967 levam a letalidade larval/pupal (SPRADLING et al., 1999). Em C. elegans genes mutados levam também a letalidade larval e diminuição do tempo de vida (MELENDEZ et al., 2003). Em Arabidopsis thaliana, mutações dos genes de autofagia (AtAPG7 e AtAPG9) não interferem no ciclo de vida destas plantas, mas as mesmas apresentam uma certa incapacidade para mobilizar nutrientes (DOELLING et al., 2002; HANAOKA et al., 2002). Já em M. musculus, mutações para o gene beclin 1 envolvido na autofagia, causam letalidade embrionária e aumento da formação de tumores nos animais heterozigotos, demonstrando a importância da autofagia na regulação do crescimento celular (QU et al., 2003; YUE et al., 2003).

\subsubsection{Apoptose}

O termo apoptose foi proposto pela primeira vez para designar um tipo de deleção celular controlada que apresenta uma importante função complementar, porém oposta à mitose, na regulação do número de células em determinado tecido (KERR; WYLLIE; CURRIE, 1972). Células que morrem por apoptose apresentam como características principais 0 arredondamento da célula, retração dos pseudópodes, redução do volume celular, condensação da cromatina, fragmentação do núcleo, pouca ou quase nenhuma modificação das organelas citoplasmáticas e manutenção da integridade da membrana plasmática, não havendo extravasamento 
de conteúdo celular, evitando um processo inflamatório local (KROEMER et al., 2005). Duas vias diferentes podem levar à ativação da apoptose, a via denominada de intrínseca, quando há perturbações mitocondriais e liberação de citocromo c, e a extrínseca, onde um determinado receptor de morte é ativado pelo seu ligante (ASHKENAZI; DIXIT, 1998; KRAMMER, 2000).

Um passo importante para execução da apoptose, tanto pela via intrínseca quanto pela via extrínseca, é a ativação de caspases, uma família de proteases de cisteínas que ubiquamente expressam um precursor de zimogênio inativo, com pouca ou nenhuma atividade (HENGARTNER, 2000; THORNBERRY; LAZEBNIK, 1998). Quando há um estímulo direcionando as células a morte, as caspases são ativadas pela clivagem de um resíduo aspártico, resultando na remoção da região inibitória e produzindo pequenas subunidades ativas (HENGARTNER, 2000).

As caspases são subdivididas em dois grandes subgrupos, as caspases iniciadoras e aquelas do tipo efetoras (HENGARTNER, 2000; THORNBERRY; LAZEBNIK, 1998). As caspases iniciadoras são responsáveis pela proteólise dos pequenos pró-domínios inativos daquelas do tipo efetoras. Quando as efetoras são ativadas, estas ficam aptas a executar a apoptose. As caspases iniciadoras possuem pró-domínios maiores e são ativadas pela ligação de diferentes moléculas adaptadoras, formando um complexo, que as tornarão ativas. Em mamíferos, as caspase 3 e 7 são as principais caspases efetoras e, por sua vez, estas são ativadas pela caspase iniciadora 9 (via intrínseca) ou pela caspase 8 (via extrínseca) (KRAMMER; ARNOLD; LAVRIK, 2007). As moléculas Apaf-1 (proteína adaptadora) e citocromo c, se ligam ao pró-domínio da caspase 9 formando o complexo denominado apoptossomo, que está apto para exercer sua função dentro da célula (RODRIGUEZ; LAZEBNIK, 1999).

Existem várias proteínas que funcionam como efetoras ou reguladoras da morte celular programada por apoptose. Membros da família Bcl-2 (B cell lymphoma 2) participam efetivamente neste tipo de controle (YOULE; STRASSER, 2008). Estas proteínas apresentam quatro regiões bem conservadas denominadas de domínios de homologia de Bcl-2 (BH) (ADAMS; CORY, 1998). A ativação de proteínas antiapoptóticas (Bcl-2 e Bcl-xL) ou pró-apoptóticas (tBid, Bax, Bad, etc) vai depender do tipo de estímulo recebido pelas células. Por exemplo, sob alguns estímulos de morte a proteína inativa Bax, que reside no citosol, é translocada e introduzida na membrana externa da mitocôndria, o que será um passo importante para liberação 
do citocromo c, enquanto que sob estímulos de sobrevivência, Bcl-2 e Bcl-xL suprimem este evento (BOSSY-WETZEL; NEWMEYER; GREEN, 1998; ESKES et al., 2000; YANG et al., 1997).

\subsubsection{Necrose}

O termo necrose tem sido utilizado para definir o tipo de morte celular desordenada sem as características da apoptose ou da autofagia. Morfologicamente, as células que morrem por necrose apresentam aumento do volume do citoplasma e das organelas, além de ruptura mecânica da membrana plasmática e extravasamento do conteúdo intracelular, contudo os núcleos de células necróticas parecem permanecem intactos. É um tipo de morte comumente induzida pela anóxia, falta de nutrientes, ou por injúrias físico-químicas como o calor, detergentes e irradiação. (DENECKER et al., 2001; KROEMER et al., 2005).

Alguns trabalhos têm sugerido que a necrose também pode ocorrer em processos fisiológicos ou durante o desenvolvimento. Utilizando drogas que inibem caspases ou inibindo geneticamente proteínas como a Apaf-1, que está intimamente relacionada com a morte celular apoptótica, ainda é possível observar morte celular interdigital com aspectos necróticos em brotos de patas de camundongos (CHAUTAN et al., 1999). Animais deficientes de Bax ou Bak, que são importantes para liberação de citocromo $\mathrm{c}$ e ativação da apoptose, nascem com o desenvolvimento dos tecidos relativamente normal e chegam a idade adulta (LINDSTEN et al., 2000). O que sugere que a morte por necrose pode ser um mecanismo compensatório para a perda de morte por apoptose nestes animais. Além disso, em algumas condições patológicas, como a isquemia cerebral ou injúrias no fígado, a morte celular pode ocorrer tanto por apoptose quanto por necrose (BEILHARZ et al., 1995; CHARRIAUT-MARLANGUE et al., 1996; LEIST et al., 1995; LEIST et al., 1997).

Apesar da necrose ser considerada um tipo de morte celular acidental e descontrolada, diversos trabalhos demonstraram que a necrose pode ocorrer de maneira controlada sendo mediada por diferentes estímulos celulares, desde moléculas como o interferon-y (IFN-y) e TNF até depleção de ATP (CHO et al., 2009; HE et al., 2009; VANLANGENAKKER et al., 2011; ZHANG et al., 2009). O termo necroptose foi proposto para designar este tipo de necrose, que é regulada pelo 
complexo (RIPK1)-RIPK3 (do inglês, receptor-interacting protein kinase 1 complex), causando desestabilização da membrana plasmática, mitocondrial e lisossomal, sendo inibida pela necrostatina-1 (nec-1) (DEGTEREV et al., 2005; VANDENABEELE et al., 2010). A inibição de caspase 8 parece ser um evento importante para ativação da necroptose, pois foi verificado que quando há o bloqueio desta caspase, as proteínas RIP1 e RIP3 não são degradadas e, assim, induzem a morte das células por necroptose (HE et al., 2009; ZHANG et al., 2009).

\subsection{Peptídeo penetrador de células (cpp)}

As membranas biológicas formam uma barreira seletiva que previne o fluxo de moléculas para dentro e para fora das células (LIPINSKI et al., 2001). Por muitos anos, uma sequência curta de aminoácidos, denominada de domínio de transdução de proteína (PTD) e também conhecida como peptídeo penetrador de células (do inglês, cell-penetrating peptide; $c p p$ ) tem sido uma importante ferramenta utilizada para internalizar moléculas impermeáveis à membrana plasmática. A utilização de "cpps" para internalização de proteínas através de membranas biológicas foi denominado de transdução de proteínas, e desde então, numerosos peptídeos carreadores foram descobertos. O peptídeo carreador presente na proteína transativadora (TAT) do vírus da imunodeficiência humana (HIV) foi descoberto em 1988 (FRANKEL; PABO, 1988; GREEN; LOEWENSTEIN, 1988) e até o momento, tem sido amplamente utilizado e bem caracterizado (BEGLEY et al., 2004; CUNHA et al., 2008; LINDSAY, 2002; SOUGHAYER et al., 2004; WADIA; DOWDY, 2002). A utilização do peptídeo carreador TAT ligado covalentemente a peptídeos racionalmente desenhados, foi utilizado por muitos estudos de cascatas de sinalização celular, tanto in vitro quanto in-vivo, proporcionando um grande avanço nessa área (BEGLEY et al., 2004).

A presença de muitos aminoácidos básicos na sua sequência (RKKRRQRRR) pode ser considerada uma explicação para a sua destreza em cruzar a membrana plasmática, embora o mecanismo exato pelo qual este carreador é internalizado pela célula ainda permaneça obscuro (EMBURY et al., 2001; SOUGHAYER et al., 2004). Estudos têm sugerido que o proteoglicano heparan-sulfato apresenta uma importante participação no processo de internalização desses peptídeos 
(NASCIMENTO et al., 2007; TYAGI et al., 2001; ZIEGLER et al., 2005). A sequência YGRKKRRQRRR, que corresponde ao TAT 47-57, parece ultrapassar a membrana plasmática diretamente e não por endocitose (SCHWARZE; DOWDY, 2000; WANG et al., 2002). 


\section{MATERIAL E MÉTODOS}

\subsection{Cultura de Células}

Para todos os experimentos, células HeLa e C6 (Rattus norvegicus) foram mantidas em estufa (atmosfera contendo $95 \%$ de ar e $5 \%$ de $\mathrm{CO}_{2}$ ) em meio DMEM (Dulbecco's Modified Eagle Medium, Gibco®, Grand Island, NY, USA) acrescido de 100.000 unidades/L de penicilina, $0,1 \mathrm{~g} / \mathrm{L}$ de estreptomicina e $10 \%$ de soro fetal bovino (Gibco®, Grand Island, NY, USA). As demais linhagens celulares utilizadas neste trabalho foram cultivadas em meio RPMI 1640 (Gibco®), Grand Island, NY, USA) e mantidas sob as mesmas condições citadas acima.

\subsection{Sincronização Celular pelo Método de Bloqueio Duplo com Timidina}

Células HeLa foram sincronizadas utilizando o método do bloqueio duplo com a timidina (Sigma-Aldrich, St. Louis, MO, USA), conforme previamente descrito (BOOTSMA; BUDKE; VOS, 1964; GALLO; KOZA; HERBST, 1986; ZHOU et al., 2009). O bloqueio com a timidina se dá devido a sua capacidade em bloquear a síntese do DNA. Resumidamente, no final da primeira exposição das células à timidina, parte da população celular encontra-se na transição G1/S ou ao longo da fase $S$ devido à inibição da síntese de DNA. Após a liberação da primeira exposição, de 9-16 horas, as células presas em G1/S e no início da fase $S$ progridem para $G 2 / M$, enquanto que aquelas que encontravam-se presas no final da fase $S$ avançam para G1. Com a segunda exposição à timidina, células que estavam em G2/M avançam para G1 e, consequentemente, ficam presas na barreira G1/S, devido à presença da timidina; aquelas que estavam entrando em $\mathrm{G} 1$ também ficam bloqueadas em G1/S (Figura 2) (HARPER, 2005). Desta forma, é possível acompanhar a maioria das células caminhando juntas ao longo de uma fase específica. 
Figura 2. Efeito do excesso de timidina na progressão do ciclo celular.
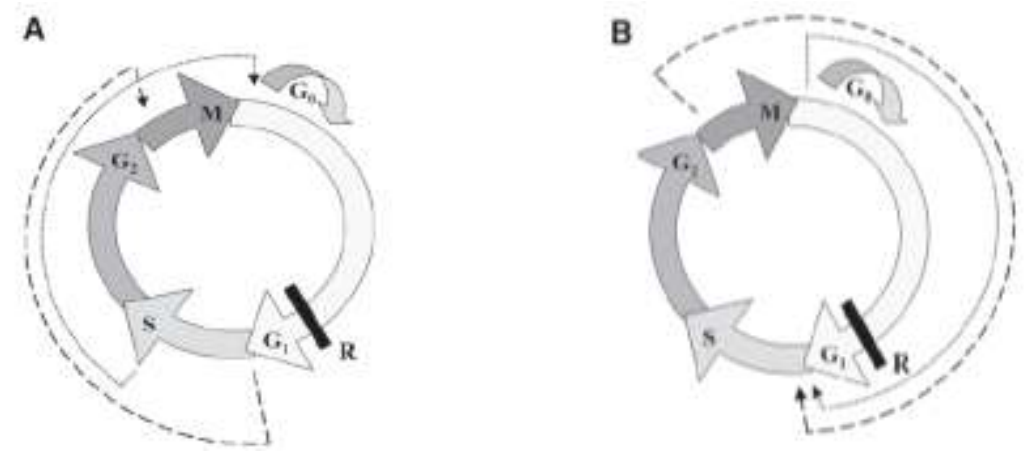

"A" corresponde ao final do primeiro bloqueio e mostra a progressão da população de células que foram tratadas com timidina $2 \mathrm{mM}$ por aproximadamente 18 horas. "B" corresponde ao segundo bloqueio e esquematiza o caminho que as células seguem após adicionais 17 horas na presença da timidina. Devido ao excesso deste nucleotídeo, as células ficam presas no início da fase de síntese do DNA (S) (Adaptado de HARPER, 2005).

As células $\left(10 \times 10^{5}\right)$ foram plaqueadas em DMEM $10 \%$ de soro fetal bovino (SFB), penicilina-streptomicina e acondicionadas em estufa $\left(37^{\circ} \mathrm{C}, 5 \% \mathrm{CO}_{2}\right)$ até o momento dos experimentos. Para realizar os ensaios de sincronização, foi adicionado DMEM sem SFB contendo timidina $2 \mathrm{mM}$ por um período inicial de 18 horas. Em seguida as células foram lavadas com tampão salina fosfato (PBS) seguido da adição de meio regular (DMEM com 10\% de SFB) por 9 horas. Passadas 9 horas, um meio novo contendo timidina $(2 \mathrm{mM})$ foi novamente adicionado às células em cultura, por mais 17 horas, para que aproximadamente $85 \%$ da população de células fosse bloqueada na fase $S$ do ciclo celular. Em intervalos de tempo estabelecidos - 4, 10 e 16 horas - que correspondem a cerca de $84 \%$ das células em S, G2/M e G0/G1, respectivamente, (Figura 2) as células foram coletadas e submetidas a diferentes tipos de ensaios.

\subsection{Citometria de Fluxo}

As análises de citometria de fluxo foram realizadas em aparelho Guava Easy City Mini Flow Cytometry (Millipore, Billerica, MA, USA). Para as análises de ciclo celular as células foram lavadas com PBS, tripsinizadas e centrifugadas a $830 \times \mathrm{g}$, 10 minutos. As amostras foram fixadas em etanol 70\% em PBS por 1 hora no gelo e em seguida centrifugadas mais uma vez (830 x g, $10 \mathrm{~min})$. O pellet foi ressuspendido em PBS contendo iodeto de propídeo (PI; $1 \mathrm{mg} / \mathrm{mL})$, RNAse (10 
$\mathrm{mg} / \mathrm{mL}$ ) e mantidas por 30 minutos no gelo. Um total de 10.000 eventos foi analisado por amostra.

\subsection{Extração e Quantificação dos Peptídeos em Diferentes Fases do Ciclo Celular}

Células HeLa $\left(10 \times 10^{5}\right)$ foram cultivadas em placas de cultura de $100 \mathrm{~mm}$ (Corning Incorporated, New York, NY, USA) em meio completo. Um total de 15 placas foi utilizado por grupo, sendo estes: grupo de células assincrônicas (controle), células sincronizadas em $\mathrm{G} 1$, células na fase $\mathrm{S}$ e, por fim, o grupo sincronizado em G2/M. Para cada grupo, alíquotas foram coletadas e analisadas por citometria de fluxo de acordo com a seção 3.3.

No momento do experimento, o meio completo foi removido e as células foram lavadas com PBS, tripsinizadas e centrifugadas a $830 \times \mathrm{g}, 5 \mathrm{~min}$. O pellet foi ressuspendido em $10 \mathrm{~mL}$ de água deionizada a $80^{\circ} \mathrm{C}$ e mantido em banho-maria na mesma temperatura por 20 minutos, sendo o lisado de células estocado a $-80 \stackrel{\circ}{\circ} \mathrm{C}$ overnight. Para a extração dos peptídeos, as amostras foram acidificadas com $10 \mu \mathrm{L}$ de $\mathrm{HCl}$ 0,1 $\mathrm{M}$ gelado (concentração final de $10 \mathrm{mM}$ de $\mathrm{HCl}$ ) e sonicadas três vezes com 20 pulsos de $4 \mathrm{~Hz}$. As amostras foram centrifugadas a $660 \times \mathrm{g}, 40$ minutos, $4^{\circ} \mathrm{C}$ e o sobrenadante coletado para extração de peptídeos. O sobrenadante foi ultracentrifugado (100.000 $\times$ g, 60 minutos, $4 \stackrel{\circ}{\circ}$ ), transferido para um filtro de exclusão molecular que impede a passagem de moléculas inferiores a $5.000 \mathrm{Da}$ (Millipore, Billerica, MA, USA), e centrifugado novamente a $660 \times \mathrm{g}, 1$ hora, $4 \stackrel{\circ}{\circ}$.

A reação de quantificação dos peptídeos foi realizada a pH 6,8 no intuito de garantir que somente os grupos amina dos peptídeos, mas não os aminoácidos livres, reagissem com a fluorescamina (Sigma, St. Louis, MO, USA), como previamente descrito (CUNHA et al., 2008; UDENFRIEND et al., 1972). Brevemente, 2,5 $\mu \mathrm{L}$ da amostra de peptídeos foram misturados com $25 \mu \mathrm{L}$ de tampão fosfato (PB) $0,2 \mathrm{M}(\mathrm{pH} 6,8)$ e $12,5 \mu \mathrm{L}$ da solução de acetona-fluorescamina a $0,3 \mathrm{mg} / \mathrm{mL}$. As amostras foram homogeneizadas em vórtex (Fisher Scientific, Bohemia, NY, USA) por 1 minuto e em seguida foram adicionados $110 \mu \mathrm{L}$ de água. A fluorescamina foi dosada com leitor de fluorescência SpectraMax M2e (Molecular Devices, Inc., 
Sunnyvale, CA, USA) em um comprimento de onda de $370 \mathrm{~nm}$ de excitação e 480 $\mathrm{nm}$ de emissão. Uma mistura de peptídeos de composição e concentração conhecidas foi utilizada como referência padrão para determinar a concentração de peptídeos nas amostras provenientes dos quatro grupos citados acima (Células assincrônicas, sincronizadas em S, G2/M e G0/G1).

\subsection{Marcação Isotópica e Espectrometria de Massas para Identificação de Peptídeos ao Longo do Ciclo Celular}

A marcação isotópica foi realizada como descrito anteriormente (CASTRO et al., 2010; CHE et al., 2007). Cada grupo de células foi marcado com um marcador isotópico TMAB-NHS (4-trimethylammoniumbutyryl). Os grupos de células sincronizadas em S, G2/M e G0/G1 foram marcados com D3, D9 e D12-TMAB, respectivamente (Corrida 1), enquanto que o grupo de células assincrônicas (controle) foi marcado com o D0-TMAB. Uma marcação reversa (Corrida 2) foi realizada para verificar a fidelidade dos resultados, sendo estes dois experimentos realizados de forma independente (Figura 3).

Um total de $50 \mu \mathrm{g}$ de extrato peptídico foi combinado com $250 \mu \mathrm{L}$ de tampão fosfato $(0,4 \mathrm{M} ; \mathrm{pH} 9,5)$ e $15 \mathrm{mg}$ de marcador TMAB por grupo. Após a adição de TMAB, a mistura foi incubada a temperatura ambiente por 60 minutos. Para impedir a existência de qualquer reagente de marcação restante, $30 \mu \mathrm{L}$ de glicina 2,5 M foi adicionado à reação. As amostras foram secas em uma centrífuga a vácuo e analisadas em um espectrômetro de massas acoplado à cromatografia líquida capilar (LC-MS/MS) Synapt G1 nanoACQUITY UltraPerformance LC System (Waters Co., Milford, MA, EUA).

Os espectros de MS foram analisados utilizando o programa MassLynx (Waters Co., Milford, MA, EUA) para identificar grupos de picos representando peptídeos marcados com os diferentes marcadores isotópicos. A quantificação foi realizada através da intensidade relativa de cada pico como descrito anteriormente (WARDMAN; FRICKER, 2011). Para sequenciamento de cada peptídeo identificado nas diferentes fases do ciclo celular, os dados de MS/MS foram analisados através do programa Mascot search engine (Matrix Science Ltd, Boston, MA, USA). 


\subsection{Síntese dos Peptídeos}

Os peptídeos 3 e 5 que foram encontrados alterados em específicas fases do ciclo celular bem como os peptídeos controles (scramble) foram sintetizados acoplados ou não ao peptídeo penetrador de células (cpp - cell penetrating peptide - que corresponde à sequência YGRKKRRQRRR, TAT 47-57), covalentemente ligado ao $\mathrm{C}$ ou $\mathrm{N}$ terminal dos peptídeos citados acima (WANG et al., 2010; WENDER et al., 2000; ZIEGLER et al., 2005). O pep5 foi também sintetizado com algumas modificações em sua sequência original. Em todos os ensaios foram utilizados peptídeos com grau de pureza $\geq 95 \%$. Todos os peptídeos utilizados nesse trabalho foram fornecidos pela Proteimax Biotecnologia LTDA, São Paulo, SP, Brasil. 
Figura 3. Esquema de marcação isotópica dos extratos peptídicos isolados nas diferentes fases do ciclo celular.

A
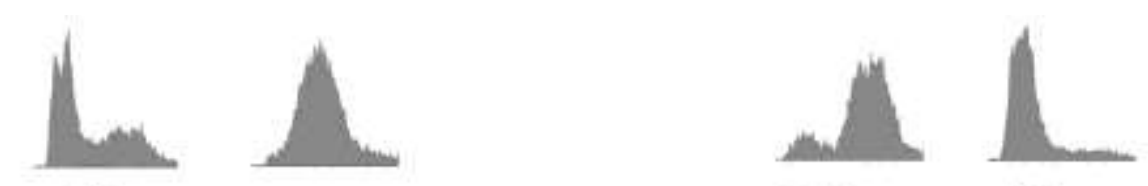

Células

Cèlulas

Assincrônicas

ems

Celulasem

G2/M

Célulasem

DO

D3

D9

D12

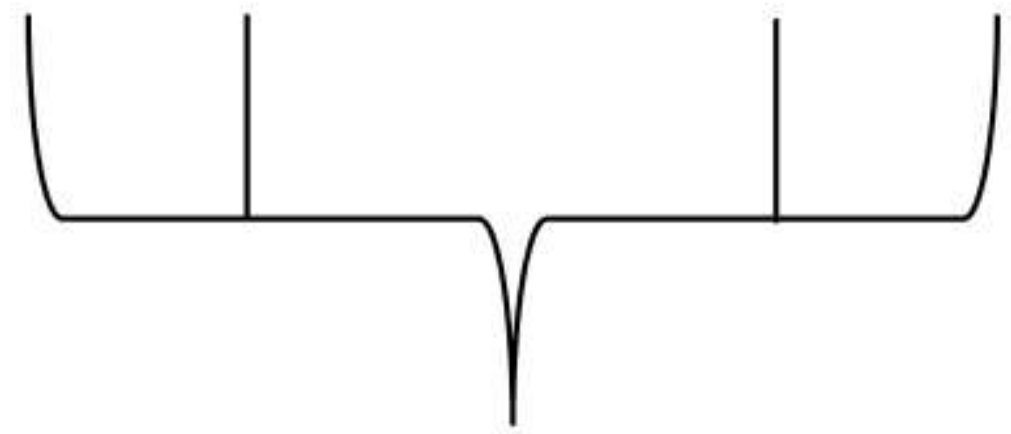

\section{Corrida 1}

B

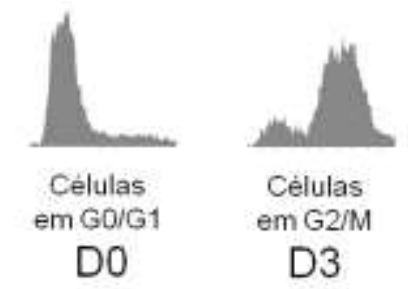

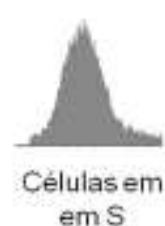

ems

D9

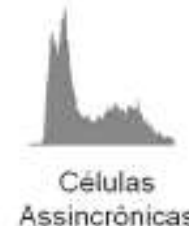

Assincrônicas

D12

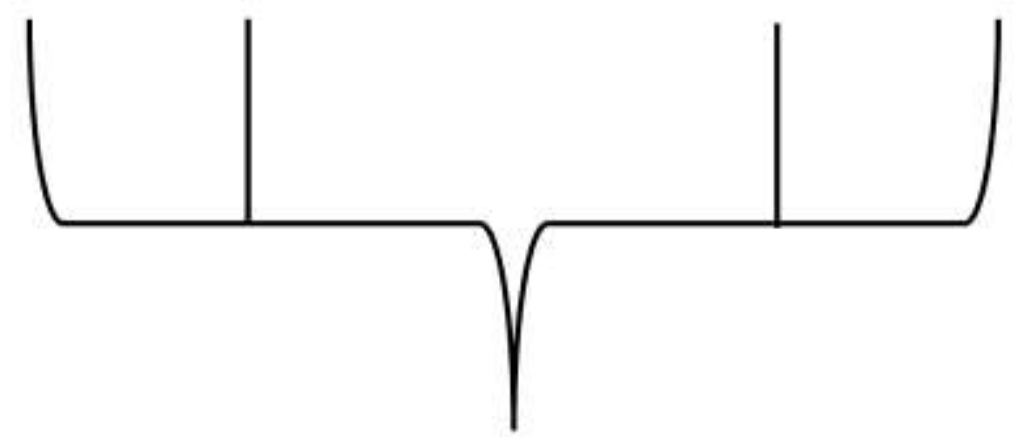

Corrida 2

Na corrida número 1 (A) os peptídeos extraídos das células assincrônicas foram marcados com o D0-TMAB, enquanto que aquelas sincronizadas em S, G2/M e G0/G1 foram marcados com D3-TMAB, D9-TMAB e D12-TMAB, respectivamente. No segundo experimento ( $B$, corrida 2$)$ a marcação foi realizada de forma inversa. Isso permite que os resultados durante a quantificação dos peptídeos sejam comparados, e assim seja confirmada a fidelidade dos dados obtidos. 


\subsection{Ensaios de Caspases Ativas}

A atividade das caspases 3/7, 8 e 9 foi analisada em extratos totais de células HeLa, previamente tratadas por 10 minutos com o pep5-cpp ou peptídeos controle na concentração de $100 \mu \mathrm{M}$, utilizando um kit luminescente (Caspase - Glo®Assay, Promega, Madison, WI, USA). O kit consiste de um substrato luminogênico específico em tampão otimizado para atividade das caspases e lise celular. A reação se dá devido à liberação de um substrato luminescente que está ligado ao domínio de clivagem para as caspases. Se há caspase ativa na amostra analisada, esta reconhece a sequência de clivagem e libera o substrato que emitirá luz. O sinal gerado é proporcional à quantidade de caspase ativa presente na amostra. Um inibidor do proteassomo (MG-132) foi adicionado à mistura no intuito de reduzir o background.

Um número aproximado de $0,2 \times 10^{5}$ células foram plaqueadas em placa branca de 96 poços (Corning Incorporated, New York, NY, USA), tratadas com os respectivos peptídeos e depois submetidas aos ensaios de caspases ativas de acordo com informações fornecidas pelo fabricante. Para cada poço contendo 100 $\mu \mathrm{L}$ do branco (somente meio de cultura), controle negativo (células não tratadas) ou células tratadas com os diferentes peptídeos, foram adicionados $100 \mu \mathrm{L}$ do reagente Caspase-Glo. Cuidadosamente as amostras foram homogeneizadas em agitador de placas (300-500 rpm por 2 minutos) e incubadas em temperatura ambiente por 30 minutos. A intensidade relativa de luminescência foi medida em luminômetro SpectraMax (Molecular Devices, Sunnyvale, CA, USA).

\subsection{Efeito do pep5 na Fosforilação de MAP Quinases Específicas ou de Seus Substratos}

Para testar o efeito do pep5 em vias de sinalização específicas, foi utilizado o Human Phospho-MAPK array (Proteome Profiler, Minneapolis, MN, USA), que permite verificar o efeito de determinada molécula na fosforilação de diferentes proteínas envolvidas na via de sinalização das MAP Quinases (Mitogen-activated protein kinase). Células HeLa foram plaqueadas $\left(10 \times 10^{5}\right)$ e tratadas com o pep5-cpp 
ou $\Delta \mathrm{N}$-pep5-cpp, $100 \mu \mathrm{M}$ por 10 minutos. Após o período de incubação, as células foram lavadas com PBS e solubilizadas com $1 \mathrm{~mL}$ do tampão de lise (Lysis buffer 6). Os lisados foram centrifugados a $14.000 \times \mathrm{g}, 5$ minutos e os sobrenadantes transferidos para microtubos. A quantificação protéica foi realizada pelo método de Bradford (BRADFORD, 1976). As amostras foram mantidas a $-80^{\circ} \mathrm{C}$ até o momento do experimento. As membranas contendo os anticorpos para cada uma das proteínas a serem testadas foram bloqueadas por 1 hora em temperatura ambiente, utilizando tampão apropriado (Array buffer 5) e sob constante agitação. Enquanto a membrana era bloqueada, as amostras foram preparadas adicionando-se $200 \mu \mathrm{g}$ de proteínas, em um volume não superior a $400 \mu \mathrm{L}$, e ajustando o volume final para 1,5 $\mathrm{mL}$ de tampão de amostra (Array buffer 1 ), de acordo com as instruções do fabricante. Foram adicionados ainda $20 \mu \mathrm{L}$ de coquetel de anticorpos de deteç̧ão $\mathrm{e}$ as amostras foram incubadas à temperatura ambiente por 1 hora. Após o período de bloqueio, o tampão foi removido das membranas e os homogenatos (amostra, tampão e coquetel) foram adicionados aos poços contendo as membranas do array e incubados overnight (OV) a $4 \stackrel{\circ}{\circ}$. Cuidadosamente cada membrana foi removida da placa e lavada com $20 \mathrm{~mL}$ de tampão de lavagem (Washer buffer 1X), num total de três lavagens de 10 minutos cada. Após a lavagem, as membranas foram incubadas por 30 minutos em temperatura ambiente, com $2 \mathrm{~mL}$ de streptavidina diluída em tampão (Array buffer 5 ). As membranas foram lavadas mais três vezes, conforme descrito acima, expostas aos reagentes quimioluminescentes $(0,5 \mathrm{~mL}$ do substrato Quimioluminescente Supersignal, Thermo Scientific, Waltham, MA, USA) e reveladas em filme de Raio X (Kodak, Rockford, IL, USA). O tempo de exposição foi de 10 minutos.

\subsection{Ensaios de Apoptose}

Para os ensaios de apoptose foi utilizado um kit de detecção (Alexa Fluor 488 Annexin V/ Dead Cell Apoptosis Kit - Invitrogen, Molecular Probes, Eugene, OR. USA) de acordo com instruções do fabricante. As células $\left(5 \times 10^{5}\right)$ foram tratadas com os peptídeos cpp, pep5-cpp, $\Delta \mathrm{N}$ ou $\Delta \mathrm{C}$-pep5-cpp por 10-30 minutos. Após este período, as células foram lavadas em PBS, tripsinizadas (Tripsina EDTA, Gibco® Grand Island, NY, USA) e centrifugadas a $830 \mathrm{~g} \times 10 \mathrm{~min}, 4^{\circ} \mathrm{C}$. Em seguida, o pellet 
foi ressuspendido em $100 \mu \mathrm{L}$ do tampão ligante de anexina $\mathrm{V}$ (1X annexin-binding buffer). Para cada $100 \mu \mathrm{L}$ foram adicionados $5 \mu \mathrm{L}$ de Alexa fluor 488 conjugado à anexina $\mathrm{V}$ juntamente com $1 \mu \mathrm{L}$ da solução de iodeto de propídeo $(100 \mu \mathrm{g} / \mathrm{mL})$. As amostras foram incubadas a temperatura ambiente por 15 minutos e, após este período, $400 \mu \mathrm{L}$ de $1 X$ annexin-binding buffer foram adicionados, homogeneizados e mantidos em gelo até o momento da análise. Os grupos foram analisados por citometria de fluxo medindo a emissão de fluorescência em $530 \mathrm{~nm}$ e $>575 \mathrm{~nm}$.

\subsection{Ação do pep5-cpp na Presença de Inibidores de Morte Celular Específicos}

Células HeLa foram incubadas na presença ou não de inibidores específicos para morte celular mediada por necrose ou apoptose. Os inibidores utilizados foram a necrostatina-1 (nec-1, $30 \mu \mathrm{M}$; Enzo Life Sciences, Farmingdale, NY, USA), inibidor de necroptose, e o IM-54 (10 $\mu \mathrm{M}$; Sigma-Aldrich, St. Louis, MO, USA) que é inibidor específico para morte celular mediada por estresse oxidativo. Adicionalmente, o inibidor de caspases qVD (30 $\mu \mathrm{M}$; SM Biochemicals, Anaheim, CA, USA), também foi utilizado nestes ensaios.

\subsection{Ação Antitumoral in vivo do pep5-cpp Usando o Modelo de Glioblastoma Induzido pela Injeção de Células C6 (glioma de rato) Intracerebral}

\subsubsection{Animais}

Ratos Wistar machos (Rattus norvegicus) foram adquiridos no biotério do Instituto de Ciências Biomédicas da Universidade de São Paulo (ICB-USP). Os ratos foram alojados cinco por gaiola, sob condições normais de habitação (luzes acesas das 6 h00 às $18 \mathrm{~h} 00$; temperatura de $22{ }^{\circ} \mathrm{C}$, umidade relativa de $40-60 \%$ ) e com livre acesso à água e comida. Os animais foram pesados e manipulados uma vez por dia (5 minutos por rato) durante a semana que precedeu a cirurgia estereotáxica. No momento da cirurgia, o peso corporal dos animais era de aproximadamente 250-350 g. Após realizados os procedimentos, os ratos foram transferidos para a sala experimental (em condições ambientais semelhantes às das instalações do biotério 
original). Todos os protocolos experimentais descritos abaixo foram previamente submetidos à aprovação do Comitê de Ética em Experimentação Animal do ICBUSP (número do protocolo: 116/08, concedido à Profa. Dra Alison Colquhoun).

\subsubsection{Geração de Tumor Experimental em Cérebro de Ratos Usando Células de Glioma C6}

As células de glioma C6 de rato foram obtidas da ATCC (BENDA et al., 1968) e mantidas em DMEM suplementado com $10 \%$ de soro fetal bovino, em condições padrão de cultivo celular conforme descrito no item "cultura de células". Para produzir tumor cerebral experimental em cérebros de ratos Wistar machos adultos, uma suspensão de células $\mathrm{C} 6\left(5 \times 10^{5}\right.$ células por $\left.4-5 \mu \mathrm{L}\right)$ em salina $(\mathrm{NaCl} 0,9 \%)$ foi injetada no cérebro dos animais. Resumidamente, os animais foram anestesiados com Ketamina-xilazina (10 mg - 1,5 mg/100 g do peso corporal) para promover uma profunda analgesia e anestesia. Os animais foram colocados em uma mesa cirúrgica estereotáxica e uma incisão mediana foi realizada. Um orifício foi perfurado cerca de 0,48 milímetros anterior e três milímetros lateral ao bregma. As células C6 em crescimento exponencial foram injetadas lentamente no striatum com auxílio de uma seringa de Hamilton, em uma profundidade de $5,4 \mathrm{~mm}$ da superfície do osso e a agulha deixada in situ por três minutos antes da remoção.

\subsubsection{Infusão Intratumoral de Peptídeos Utilizando Microbombas ALZET}

Duas semanas depois das células de glioma C6 terem sido inoculadas no cérebro dos ratos sadios, microbombas osmóticas Alzet (ALZET Model 2002, ALZET Osmotic Pumps $0.5 \mu \mathrm{L} / \mathrm{h}, 14$ days, $200 \mu \mathrm{L}$; Palo Alto, CA, USA) foram cirurgicamente implantadas para infusão, por 14 dias, dos peptídeos a serem testados (pep5-cpp ativo ou $\Delta$ Npep5-cpp inativo). A concentração dos peptídeos (100 $\mu \mathrm{M})$ foi escolhida com base em nossos resultados prévios usando linhagens celulares.

Quatro horas antes do início da cirurgia (dia 0) para implantação, as microbombas foram preenchidas com o pep5-cpp ou $\Delta$ Npep5-cpp diluídos em fluido cerebroespinhal artificial (433 mg NaCl, 11,2 $\mathrm{mg} \mathrm{KCl}, 10,3 \mathrm{mg} \mathrm{CaCl}$, 8,15 mg MgCl , $10,7 \mathrm{mg} \mathrm{Na}_{2} \mathrm{HPO}_{4}, 1,35 \mathrm{mg} \mathrm{NaH} \mathrm{PO}_{4}$ em $50 \mathrm{~mL}$ de $\mathrm{H}_{2} \mathrm{O}$ MilliQ) de forma estéril a 37 
${ }^{\circ} \mathrm{C}$. A velocidade de bombeamento das bombas miniosmóticas foi de $0.5 \mu \mathrm{L} / \mathrm{h}$. Uma cânula guia de aço inoxidável foi implantada no ventrículo lateral esquerdo sob anestesia com halotano, tal como anteriormente publicado (LABEUR et al., 1995). A cânula foi ligada com tubagem de polietileno para a minibomba osmótica Alzet, a qual foi posicionada subcutaneamente na região dorsal do rato.

\subsubsection{Análises Histopatológicas}

Após 14 dias de infusão, os animais foram sacrificados por perfusão transcardíaca com formaldeído $4 \%$ em tampão fosfato $0,1 \mathrm{M}, \mathrm{pH} 7,4$. Após perfusão, os cérebros foram removidos, fixados em formol a $4 \%$ e crioprotegidos com sacarose $30 \%$ em PBS. Os cortes foram obtidos em micrótomo de congelamento. As fatias de cérebro de $30 \mu \mathrm{m}$ foram coradas com $\mathrm{HE}$ e o volume do tumor foi analisado em microscópio, considerando tanto o comprimento (L) como a largura (W) do tumor de acordo com a fórmula $\mathrm{V}=\pi / 6 \times \mathrm{L} \times \mathrm{W} \times \mathrm{H}$. As maiores áreas de tumor foram medidas utilizando o software de análise de imagem (Image ProPlus, Rockville, MD, USA). Este procedimento foi aprovado pela Comissão de Ética Para Experimentação Animal do Instituto de Ciências Biomédicas - número do protocolo 116/08, concedido à Profa. Dr ${ }^{\mathrm{a}}$ Alison Colquhoun.

\subsection{Efeito do Pep5 na Atividade Quimotripsina do Proteassomo}

Inicialmente, células HeLa foram tratadas ou não com o pep5-cpp (100 $\mu \mathrm{M})$ por 24 horas em DMEM sem soro fetal bovino. Após o período de tratamento, as células foram lavadas duas vezes com PBS e lisadas em tampão de lise (Tris- $\mathrm{HCl}, \mathrm{pH} 7.6 \mathrm{a}$ $0{ }^{\circ} \mathrm{C}, 150 \mathrm{mM} \mathrm{NaCl}, 1 \% \mathrm{NP}-40$ ) no gelo por 30 minutos, sem inibidores de proteases (FOSS et al., 1998). Os extratos de células foram centrifugados a $17.900 \times \mathrm{g}$ por 10 minutos, os sobrenadantes coletados em microtubos e a quantidade de proteína (20 $\mu \mathrm{g}$ de proteína por amostra) foi determinada pelo método de Bradford, usando albumina bovina como padrão. O substrato específico para atividade quimotripsina do proteassomo, o Suc-LLVY-GloTM (Promega, Madison, WI, USA) foi utilizado para determinar a atividade proteassomal de acordo com instruções do fabricante. As amostras foram pipetadas em placas brancas de 96 poços (Corning, New York, NY, USA) e o substrato luminescente foi adicionado a cada um dos poços contendo os 
extratos tratados ou não com o pep5-cpp. O volume final por poço foi de $100 \mu \mathrm{L}$ (50 $\mu \mathrm{L}$ de amostra mais $50 \mu \mathrm{L}$ do substrato) e o período de incubação foi de aproximadamente 30 minutos. A leitura da luminescência relativa foi realizada em leitor de placas SpectraMax L (Molecular Devices, Sunnyvale, CA, USA).

O mesmo ensaio foi realizado in vitro, sendo que o extrato total de células HeLa foi incubado por 10 minutos com o pep5 $(50-200 \mu \mathrm{M})$ sem 0 cpp. $O$ inibidor específico do proteassomo, a Lactacistina $(10 \mu \mathrm{M})$, foi utilizado como controle positivo.

\subsection{Formas de Análises dos Resultados}

Os dados de cada experimento foram apresentados como média \pm erro padrão da média (SEM) e analisados através dos testes estatísticos One way-ANOVA e Two way-ANOVA, utilizando o GraphPad Prism, versão 5.0. Os resultados foram considerados significativos quando $p \leq 0,05, p \leq 0,01$ ou $p \leq 0,001$. 


\section{RESULTADOS}

\subsection{Sincronização Celular por Excesso de Timidina}

A hipótese inicial do nosso trabalho era que a concentração relativa de alguns peptídeos intracelulares, semelhante à de certas proteínas específicas, pudesse variar ao longo do ciclo celular e talvez até mesmo contribuir para o seu controle. Para este fim, células HeLa foram sincronizadas pelo método do bloqueio duplo com a timidina, no intuito de poder isolar e caracterizar o conteúdo peptídico em cada fase do ciclo celular.

Após sincronização alíquotas de cada grupo foram coletadas e analisadas por citometria de fluxo. Na figura 4 podemos observar a porcentagem de células em cada fase do ciclo celular, tanto do grupo de células assincrônicas (aquelas livres do efeito promovido pelo excesso de timidina - controle; Figura 4A), quanto daquelas que foram sincronizadas. Após a liberação do segundo bloqueio, as células finalmente encontram-se bloqueadas no início da fase $S$, nos permitindo assim seguir um grupo de células (aproximadamente 84\%) em cada uma das fases do ciclo celular. Quatro horas depois da liberação do bloqueio duplo, grande parte da população celular encontrava-se sincronizada na fase $S$ (Figura 4B); dez horas depois da liberação este grupo de células se encontrava progredindo ao longo da fase G2/M (Figura 4C), enquanto que 16 horas depois de cultivadas em meio sem timidina, as mesmas estavam ao longo da fase G1 (Figura 4D).

\subsection{Extração e Quantificação dos Peptídeos ao Longo do Ciclo Celular}

Após confirmação por citometria de fluxo, os peptídeos intracelulares foram extraídos de cada um dos grupos citados acima. Após marcação e identificação por espectrometria de massas, foram sequenciados 19 peptídeos encontrados ao longo do ciclo celular de células HeLa. A tabela mostra a ordem de identificação destes peptídeos, bem como as proteínas que deram origem aos mesmos (Tabela 1).

Dos 19 peptídeos identificados somente dois estavam alterados em fases específicas do ciclo celular, peptídeos 3 e 5, numerados de acordo com a sua ordem de identificação. O fragmento da proteína ribossomal S21 (pep3) está aumentado 
cerca de 1.9 vezes na fase $S$ e 1.8 na fase G2/M quando comparados ao grupo de células assincrônicas, enquanto que o fragmento da ciclina D2 (G1/S específica) (pep5), está aumentado cerca de $2 x$ somente na fase $S$ do ciclo celular. Os espectros de MS mostram o perfil destes peptídeos em cada uma das fases analisadas, sendo possível observar a relação semiquantitativa de um mesmo peptídeo nos diferentes grupos (Figura 5).

Os peptídeos 3 e 5 (pep3 e pep5, respectivamente) foram investigados no que diz respeito à sua atividade biológica (por exemplo, a regulação do ciclo celular). Pep3, pep5 e um peptídeo controle (SCB) foram sintetizados livres ou covalentemente ligados ao peptídeo penetrador de células (cpp), no C- ou Nterminal. 
Figura 4. Sincronização de células HeLa usando timidina 2 mM.
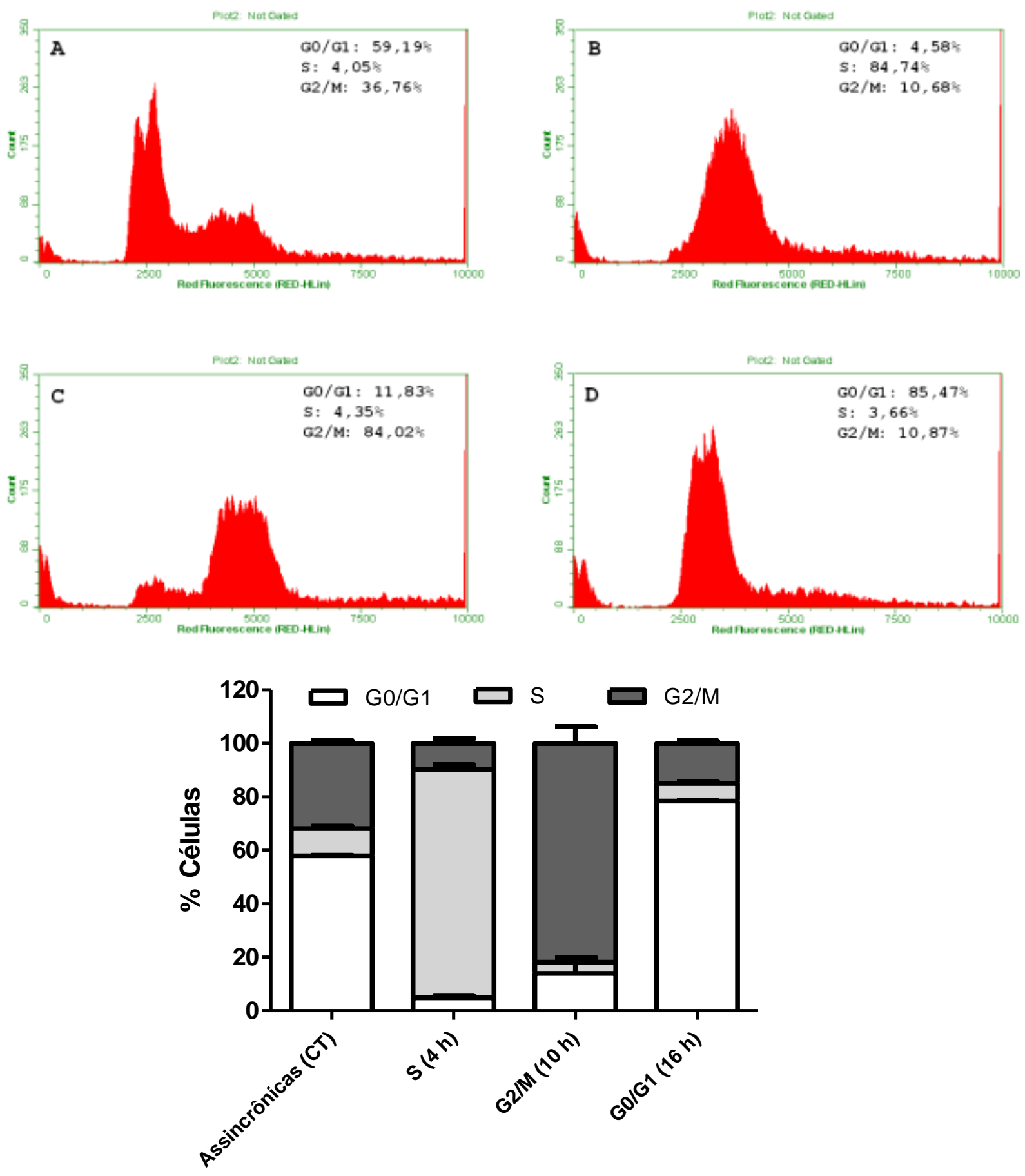

A percentagem de células em cada fase foi determinada por citometria de fluxo. Os histogramas representam o conteúdo de DNA das células em $S$, G2/M e G1, respectivamente, 4, 10 e 16h após o bloqueio duplo com a timidina, ou células assincrônicas que corresponde ao grupo controle. A intensidade de fluorescência foi medida após a adição de iodeto de propídio às células. Os histogramas e o gráfico (média e SEM) aqui apresentados são representativos de três experimentos realizados em triplicatas e de forma independente. A: Controle (células assincrônicas), B, C e D: células sincronizadas em S, G2/M e G0/G1. 
Tabela 1. Proteínas precursoras e peptídeos identificados em células HeLa durante a progressão do ciclo celular.

\begin{tabular}{|c|c|c|c|c|c|c|c|c|c|}
\hline \multirow[t]{2}{*}{ Proteína precursora } & \multirow[t]{2}{*}{ Sequência } & \multirow[t]{2}{*}{$\mathbf{z}$} & \multirow[t]{2}{*}{ \#T } & \multirow[t]{2}{*}{ M Obs } & \multirow[t]{2}{*}{ M Teór } & \multirow[t]{2}{*}{ ppm } & \multicolumn{3}{|c|}{ Razão } \\
\hline & & & & & & & G1/CT & $\mathrm{S} / \mathrm{CT}$ & G2/CT \\
\hline Peptidyl-prolyl cis-trans isomerase A & 1 & 4 & 3 & 1374,7 & 1374,7 & $-13,4$ & $1,19 \pm 0,24$ & $2,11 \pm 2,13$ & $1,75 \pm 1,17$ \\
\hline $40 S$ ribosomal protein $\mathrm{S} 21$ & 2 & 3 & 3 & 1077,5 & 1077,6 & $-52,4$ & $0,71 \pm 0,21$ & $0,69 \pm 0,13$ & $0,83 \pm 0,08$ \\
\hline $40 S$ ribosomal protein $\mathrm{S} 21$ & 3 & 3 & 3 & 1148,6 & 1148,6 & $-45,0$ & $1,52 \pm 0,41$ & $1,95 \pm 0,14$ & $1,88 \pm 0,32$ \\
\hline $10 \mathrm{kDa}$ heat shock protein, mitochondrial & 4 & 3 & 3 & 1485,7 & 1485,8 & $-62,7$ & $1,39 \pm 0,51$ & $1,57 \pm 1,16$ & $1,29 \pm 0,96$ \\
\hline G1/S-specific cyclin-D2 & 5 & 2 & 2 & 1055,5 & 1055,6 & $-164,2$ & $1,27 \pm 0,67$ & $2,16 \pm 0,40$ & $1,22 \pm 0,47$ \\
\hline TOX high mobility group box family member 3 & 6 & 3 & 1 & 1082,6 & 1082,6 & 10,4 & $0,70 \pm 0,30$ & $0,58 \pm 0,06$ & $1,24 \pm 0,62$ \\
\hline 40 S ribosomal protein $\mathrm{S} 21$ & 7 & 2 & 2 & 949,4 & 949,5 & $-73,1$ & $0,98 \pm 0,27$ & $0,94 \pm 0,32$ & $0,85 \pm 0,17$ \\
\hline Polypyrimidine tract-binding protein 1 & 8 & 3 & 1 & 855,5 & 855,5 & $-64,4$ & $1,15 \pm 0,12$ & $1,19 \pm 0,04$ & $1,61 \pm 0,44$ \\
\hline Activated RNA polymerase II transcriptional coactivator $\mathrm{p} 15$ & 9 & 4 & 3 & 1628,8 & 1628,9 & $-45,0$ & $1,60 \pm 0,39$ & $1,94 \pm 0,12$ & $1,84 \pm 0,39$ \\
\hline PPIA_HUMAN, Peptidyl-prolyl cis-trans isomerase A & 10 & 2 & 1 & 1245,6 & 1245,6 & $-52,4$ & $0,71 \pm 0,28$ & $0,69 \pm 0,33$ & $0,83 \pm 0,18$ \\
\hline Potassium channel subfamily T member 1 & 11 & 2 & 1 & 1399,4 & 1399,8 & $-286,5$ & $0,84 \pm 0,06$ & $0,71 \pm 0,19$ & $0,76 \pm 0,16$ \\
\hline Dipeptidyl peptidase 1 & 12 & 2 & 1 & 1329,8 & 1329,6 & 162,9 & $0,96 \pm 0,08$ & $0,33 \pm 0,46$ & $0,66 \pm 0,93$ \\
\hline Hemopexin & 13 & 2 & 2 & 851,4 & 851,5 & $-115,6$ & $0,61 \pm 0,09$ & $0,57 \pm 0,63$ & $0,41 \pm 0,35$ \\
\hline Cytochrome c oxidase subunit $5 \mathrm{~A}$, mitochondrial & 14 & 2 & 2 & 1356,6 & 1356,7 & $-52,2$ & $0,62 \pm 0,14$ & $0,49 \pm 0,20$ & $0,51 \pm 0,12$ \\
\hline Cofilin-1 & 15 & 2 & 2 & 1226,6 & 1226,7 & $-59,7$ & $1,14 \pm 0,01$ & $1,07 \pm 0,23$ & $1,03 \pm 0,17$ \\
\hline Lysosomal protective protein & 16 & 2 & 1 & 1070,5 & 1070,5 & $-39,2$ & 0,46 & 0,73 & $0, \overline{7} 1$ \\
\hline Protocadherin alpha-3 & 17 & 2 & 2 & 928,4 & 928,5 & $-86,7$ & $0,82 \pm 0,16$ & $0,83 \pm 0,04$ & $0,97 \pm 0,08$ \\
\hline Mitogen-activated protein kinase kinase kinase 2 & 18 & 2 & 1 & 751,3 & 751,4 & $-95,4$ & 0,35 & 1,23 & 0,80 \\
\hline Cell division cycle protein 23 homolog & 19 & 3 & 3 & 1096,6 & 1096,7 & $-147,3$ & $1,63 \pm 1,12$ & $0,72 \pm 0,49$ & $1,67 \pm 2,01$ \\
\hline
\end{tabular}

"Sequência", classificação dos peptídeos que foram identificados; z, a carga dos peptídeos, \# T, o número de tags no peptídeo identificado; M Obs, massa observada, $\mathrm{M}$ Teór, massa teórica do peptídeo; ppm, partes por milhão; Razão, quantificação relativa do peptídeo na fase indicada do ciclo celular (G1, S ou G2)/ quantificação relativa do peptídeo em células assincrônicas. 
Figura 5. Espectros de MS ilustrando as análises semi-quantitativas de peptídeos isolados a partir de extratos de células HeLa sincronizadas (S, G2/M, e G1) ou assincrônicas.
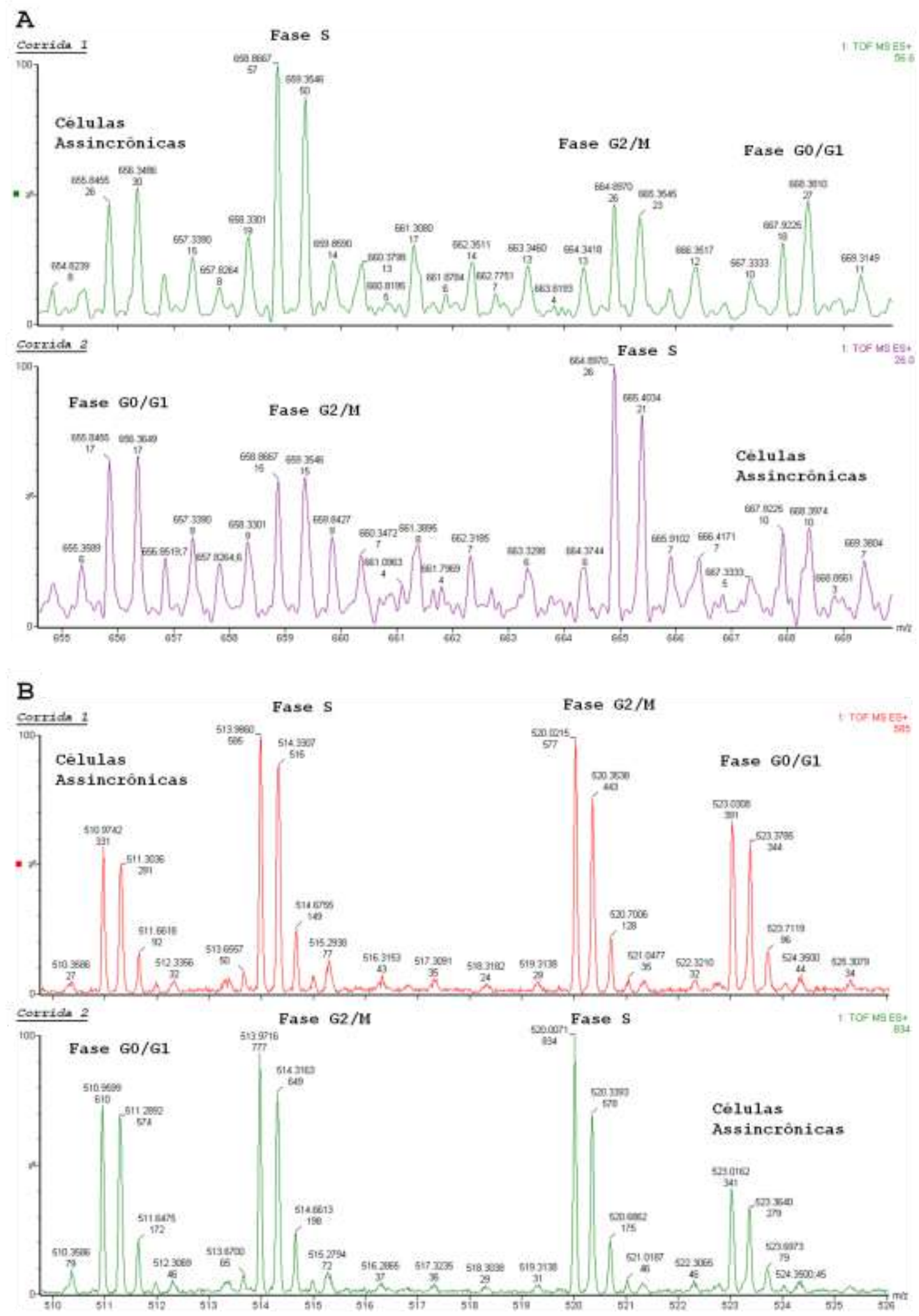

As células HeLa foram sincronizadas com timidina $2 \mathrm{mM}$ e os peptídeos marcados com isótopos TMAB (D0, D3, D9 e D12). A e B mostram os espectros de MS representativos de dois peptídeos (5 e 3), que de forma reprodutível, estavam alterados durante o ciclo celular 
de células HeLa. Os dados aqui apresentados são representativos de dois experimentos realizados de forma independente.

\subsection{Efeito de Peptídeos Intracelulares Identificados ao Longo do Ciclo Celular em Células HeLa}

Inicialmente, células HeLa foram incubadas, durante 24 horas, na presença dos peptídeos pep3 e pep5 e de um peptídeo controle (SCB) em uma concentração fixa $(100 \mu \mathrm{M})$. As células foram tratadas com os peptídeos ligados ou não ao peptídeo carreador (cpp). Células que foram tratadas com o cpp sozinho, peptídeo controle e pep3 não sofreram nenhuma alteração significativa durante a progressão do ciclo celular. Contudo, grupos tratados com o pep5, apenas quando esse estava ligado covalentemente ao cpp, tiveram aumento no número de células mortas. A porcentagem de morte celular foi de aproximadamente $90 \%$ quando o pep5 foi sintetizado com o cpp no C terminal (pep5-cpp), enquanto que aquele com o cpp no $\mathrm{N}$ terminal (cpp-pep5) causou apenas $40 \%$ de morte nesta mesma linhagem (Figura 6A). Utilizando microscopia óptica, também é possível observar diferenças na morfologia das células quando tratadas com o pep5-cpp, em comparação àquelas submetidas ao tratamento com os peptídeos controle (cpp ou SCB-cpp) ou, até mesmo, com o pep5 livre (Figura 6B).

Em seguida as células HeLa foram tratadas com os mesmos peptídeos, mas em diferentes concentrações. Nem o cpp sozinho, nem o peptídeo controle induziram aumento da porcentagem de células mortas. Já o pep5 com o cpp ligado ao $\mathrm{N}$ terminal (cpp-pep5) não foi capaz de induzir morte celular em concentrações menores que $100 \mu \mathrm{M}$ (Figura 7A). Como pode ser observado no gráfico, o pep5 só induziu morte celular em concentrações acima de $50 \mu \mathrm{M}$ (Figura 7B). Realizando experimento de curva de tempo, foi possível notar que o efeito produzido pelo pep5cpp já é observado a partir de 2 horas de tratamento (Figura 7C).

Sabendo que este fragmento de ciclina D2 tem nove aminoácidos em sua sequência original, o próximo passo foi verificar o efeito de deleções neste nonapeptídeo. Quando removemos apenas um aminoácido do N terminal do pep5cpp ( $\Delta \mathrm{N}$-pep5-cpp), o efeito indutor de morte celular foi abolido. Contudo, ao deletar 1, 2 ou até 3 aminoácidos no $C$ terminal, o pep5-cpp continuou ativo (Figura 8A). 
Figura 6. Efeito de peptídeos intracelulares no ciclo celular e viabilidade de células HeLa.

A

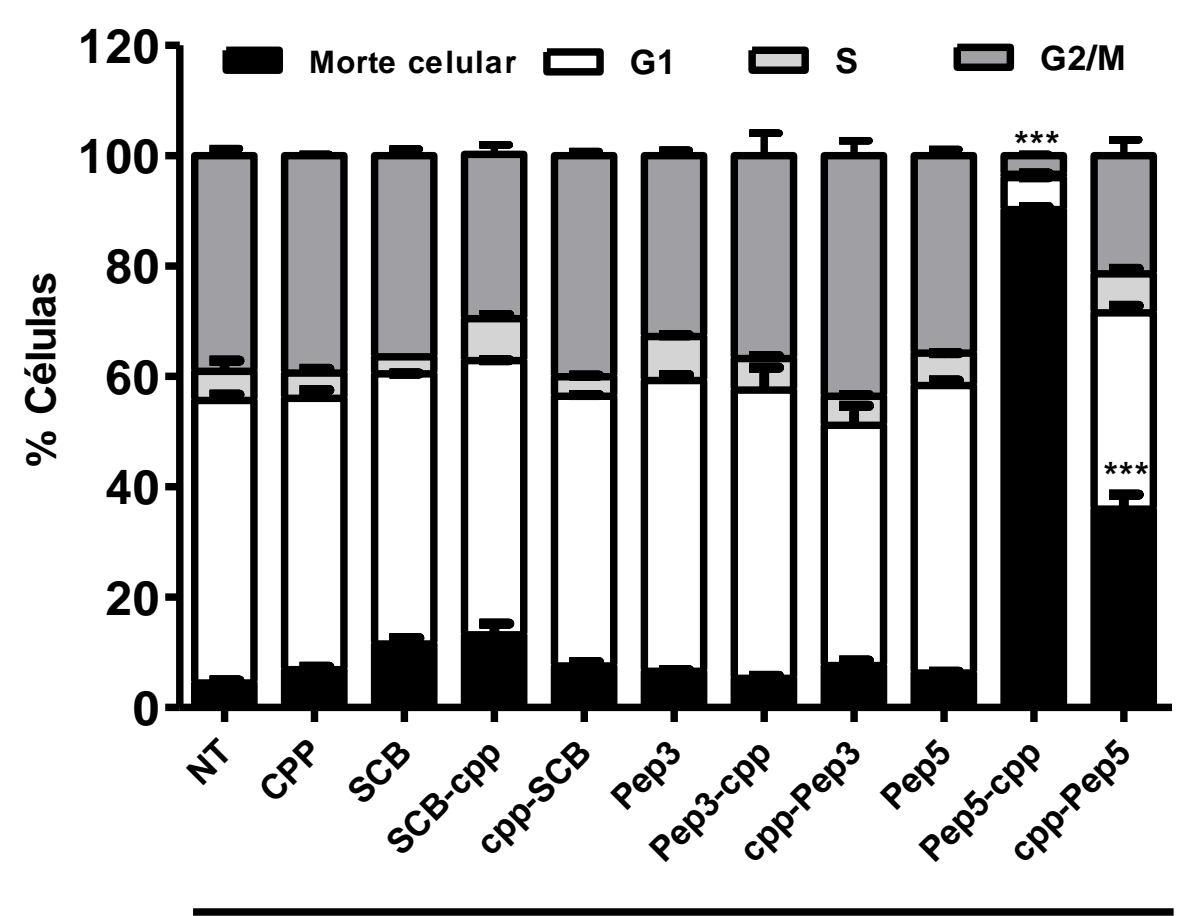

Peptídeos [100 uM]
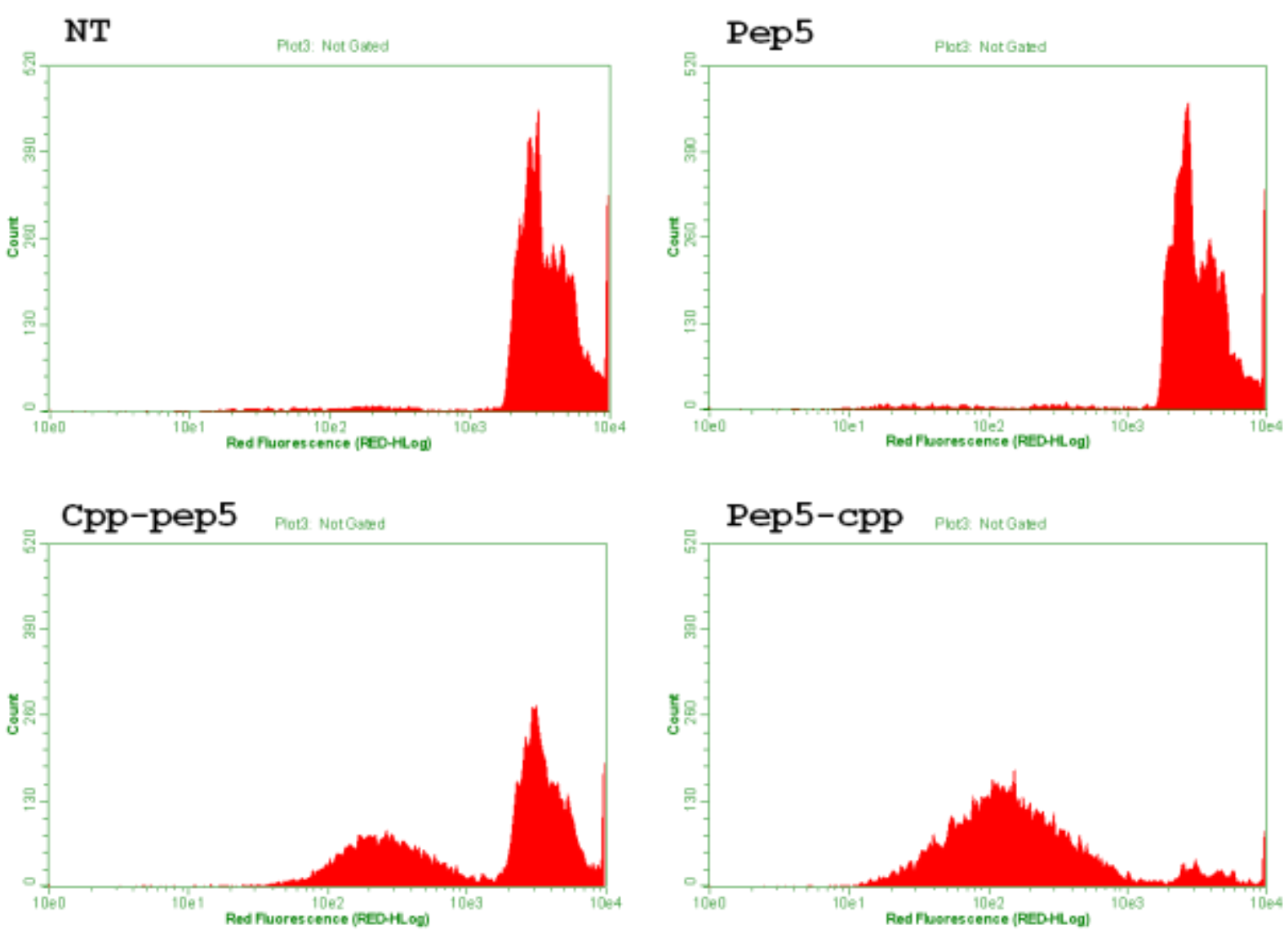
B

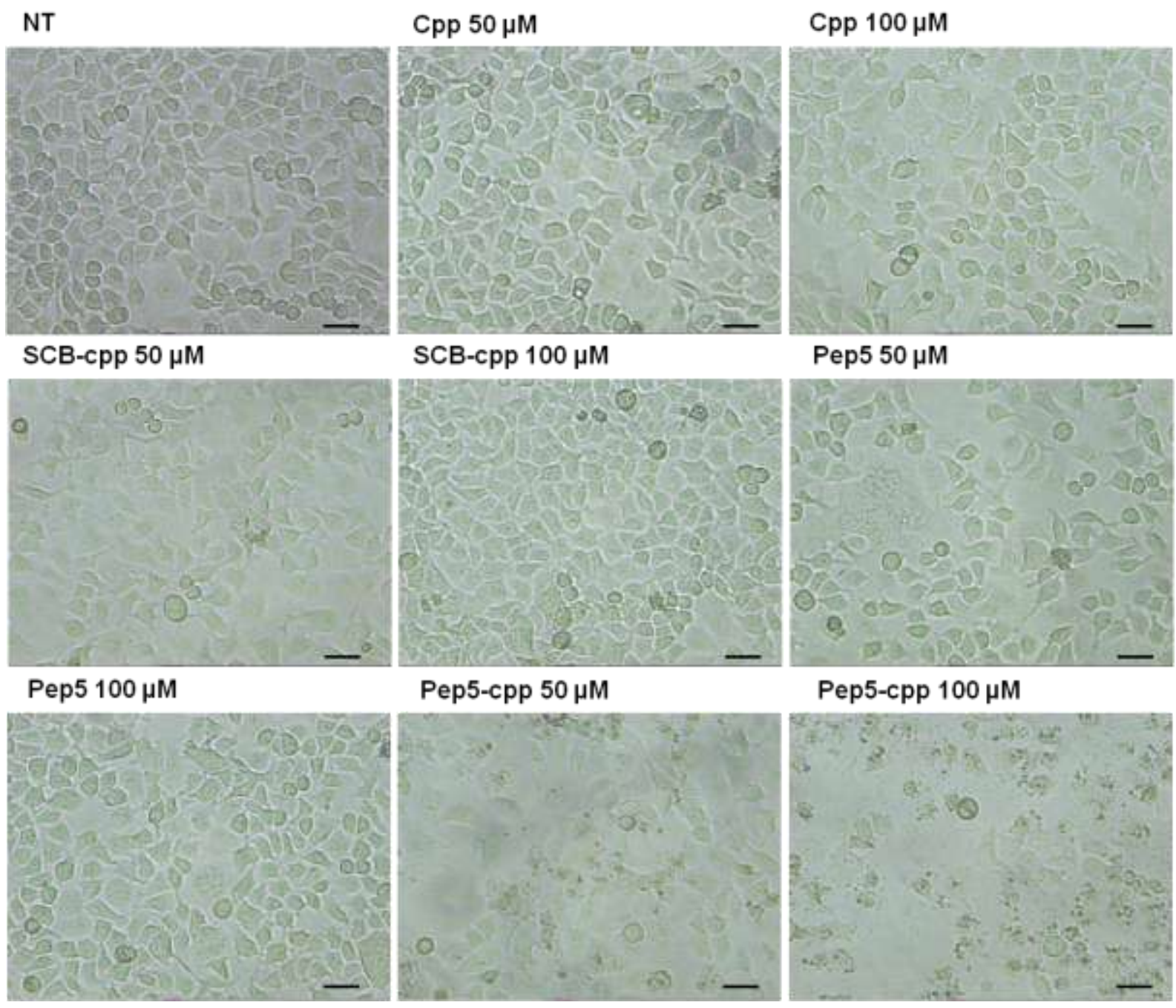

(A) As células HeLa foram tratadas com os peptídeos 3 (pep3) ou 5 (pep5) livres ou ligados peptídeo penetrador de células (CPP), CPP sozinho ou com peptídeo controle (SCB), durante 24 horas. Em seguida, as células foram fixadas em etanol a 70\% e analisadas, incubadas com iodeto de propídio (PI) e analisadas por citometria de fluxo. Os resultados foram considerados significativos quando $\left.p \leq 0,001{ }^{* * *}\right)$. Os dados aqui apresentados são representativos de três experimentos independentes realizados em triplicata. NT (não tratado); pep-cpp (cpp fundido ao C-terminal dos peptídeos); cpp-pep (cpp fundido ao N terminal dos peptídeos). Os histogramas mostram a diferença entre os grupos tratados com o pep5 ligado ou não ao cpp no $\mathrm{N}$ ou $\mathrm{C}$ terminal. (B) Células HeLa tratadas e fotografadas em microscópio óptico após $24 \mathrm{~h}$ de tratamento. É possível observar a diferença na morfologia das células que foram submetidas ao tratamento com o pep5-cpp (50 e $100 \mu \mathrm{M}$ ), quando comparadas aos grupos controle. Barra de escala $50 \mu \mathrm{m}$. 
Figura 7. Efeito de pep5-cpp em células HeLa.

A

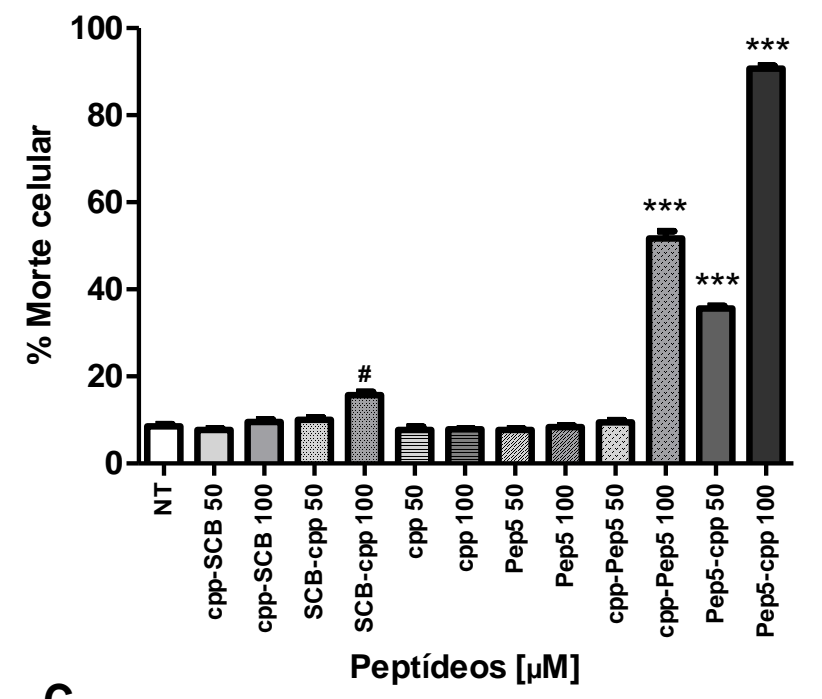

B

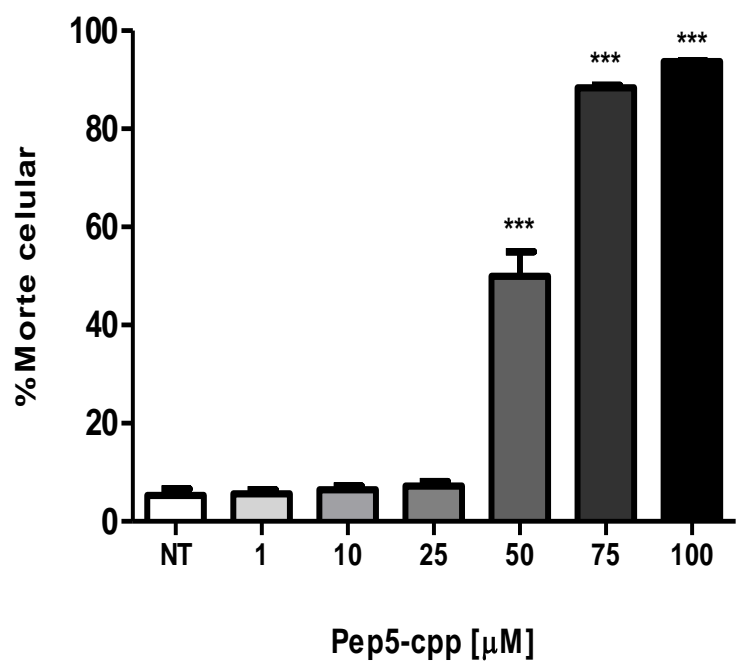

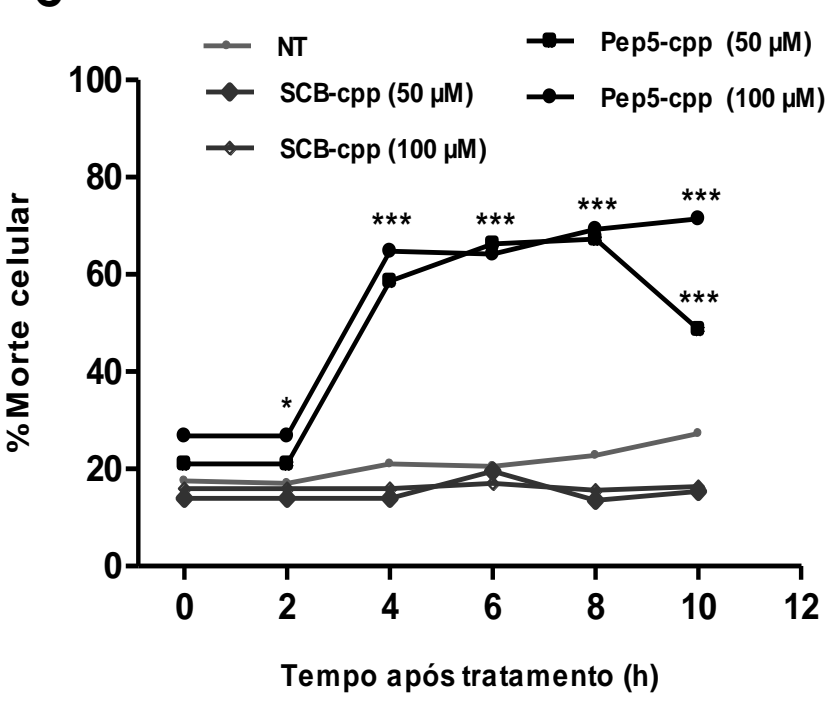

(A) Células HeLa foram tratadas com os peptídeos pep5, peptídeo penetrador de células (cpp), ou peptídeo controle (SCB) durante 24 horas. (B) As células foram incubadas com pep5-cpp em diferentes concentrações $(1,10,25,50,75$ e $100 \mu \mathrm{M})$ durante 24 horas. (C) Células tratadas com pep5-cpp ou SCB durante 10 horas a 50 e $100 \mu \mathrm{M}$. Depois de todos os ensaios, as células foram fixadas em etanol a 70\% (em PBS), incubadas com iodeto de propídio (PI) e analisadas por citometria de fluxo. Os resultados foram considerados significativos quando $\left.p \leq 0,001{ }^{(* *}\right)$ ou $p \leq 0,05(\#)$. Os dados aqui apresentados são representativos de três experimentos realizados de maneira independente e em triplicata. NT (não tratado); pep-cpp (cpp fundido ao C-terminal dos peptídeos); cpp-pep (cpp fundido ao N-terminal dos peptídeos).

Outro experimento realizado foi promover substituições de alguns aminoácidos presentes na menor sequência ativa do pep5 (Figura 8A, C). As leucinas (Leu) foram modificadas por alaninas (Ala) e o efeito destas modificações na atividade do pep5 foi verificado em células HeLa. O gráfico mostra que quando modificado, não importando a posição, ou o número de Leu substituídas, o pep5 ( $A, B$ e C) perde a 
capacidade de induzir morte celular na linhagem utilizada (Figura 8B). Por fim, foi sintetizada outra versão do pep5, sendo a menor porção ativa deste fragmento de ciclina acetilada na região do $\mathrm{N}$ terminal (Ac-pep5-cpp). Como observado na figura 7, o Ac-pep5-cpp teve a sua potência reduzida quando comparado com o pep5-cpp (Figura 8C).

\subsection{Efeito do pep5-cpp em Outras Linhagens Celulares}

O efeito do pep5-cpp também foi verificado em outras linhagens celulares, como câncer de mama (SKRB), melanoma (SK-Mel 28, Mel-85, SBCl-2), tumor de tiróide (TPC-1, KTC-2), glioblastoma de rato (células C6) e uma linhagem normal de tiróide (Nthy-ori 3-1). Como observado, o pep5-cpp na maior concentração utilizada em células HeLa $(100 \mu \mathrm{M})$ foi capaz de induzir morte celular em todas as linhagens utilizadas (Figura 9A). Isso mostra que o pep5-cpp está induzindo a morte de células independente do tipo celular tratado, não sendo um efeito específico de células HeLa. Já para as linhagens de câncer de mama, MDA-MB-231e MCF-7, o efeito do pep5-cpp foi observado em concentrações inferiores àquelas utilizadas nas linhagens da figura 9A (Figura 9B). Este resultado sugere que o efeito do pep5-cpp ocorre de acordo com o tipo de célula tratada, sendo algumas linhagens mais sensíveis ao tratamento.

A porcentagem de morte celular após 24 horas de tratamento, para cada linhagem utilizada, pode ser observada na tabela 2. 
Figura 8. Efeito de modificações na sequência original do pep5-cpp.
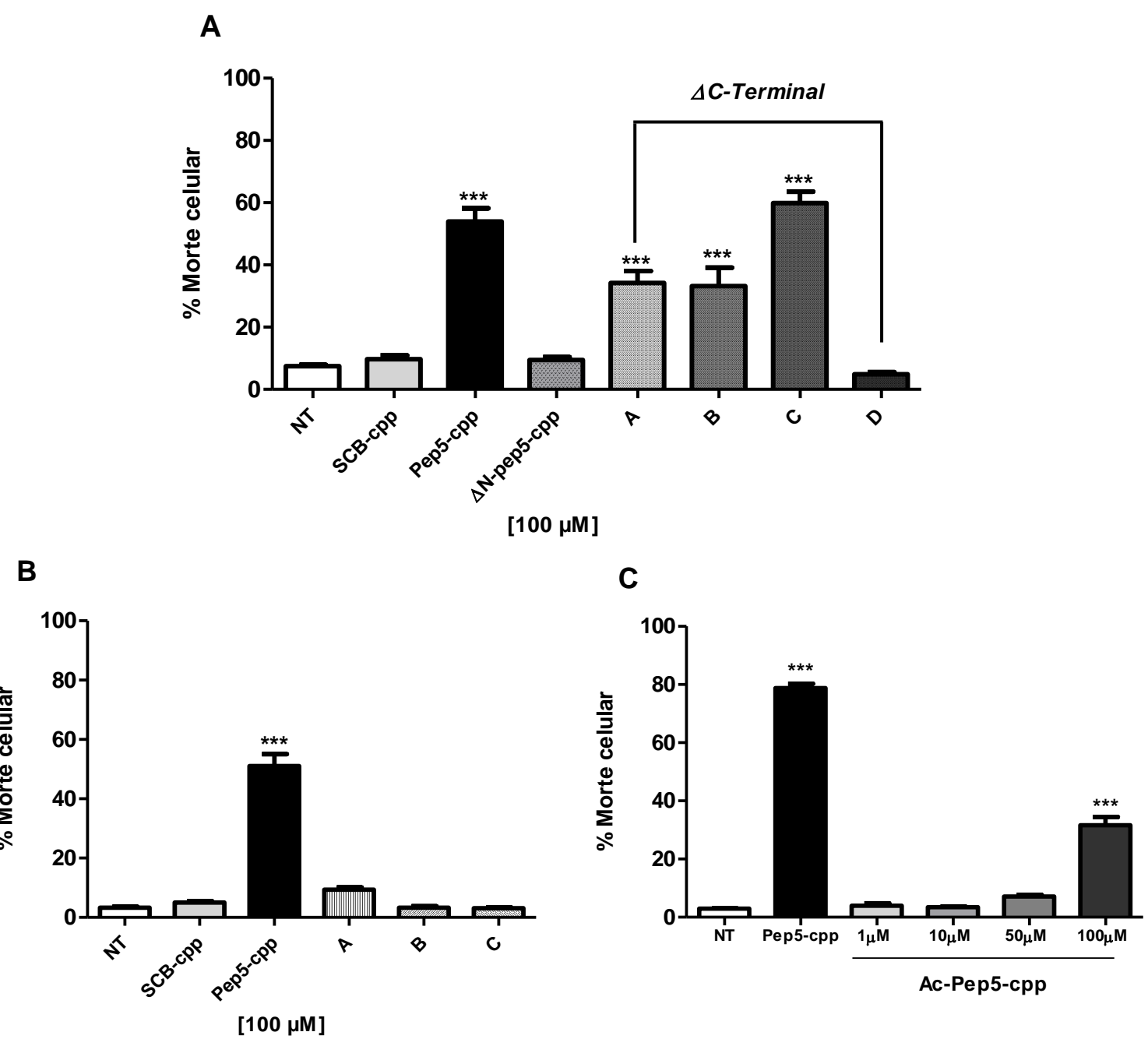

(A) Efeito de deleções na sequência do pep5. As células foram tratadas com pep5-cpp, SCB e $\Delta \mathrm{N}$ - ou $\Delta \mathrm{C}$-pep5-cpp (pep5 com deleções) durante 24 horas (100 $\mu \mathrm{M})$. NT: não tratado, SCB (controle); $\Delta N$-pep5-cpp: eliminação de um aminoácido no $N$ terminal; $A, B, C$ e $D$ : deleções de 1, 2, 3 e 4 aminoácidos no $C$ terminal, respectivamente. (B) Análise das substituições na sequência original do pep5. As células foram tratadas com pep5-cpp, SCB ou pep5-cpp modificado durante 24 horas $(100 \mu \mathrm{M})$. A, B e C representam o pep5 com uma ou mais substituições de Leu, na sequência original, por Ala. (C) Células tratadas com pep5cpp $(100 \mu \mathrm{M})$ ou pep5-cpp acetilado em diferentes concentrações $(1,10,50$ e $100 \mu \mathrm{M})$ durante 24 horas. Todas as análises foram realizadas por citometria de fluxo. Ac-pep5-cpp (pep5 acetilado no $\mathrm{N}$-terminal). Os dados a média e o SEM de três experimentos realizados em triplicata. Os resultados foram considerados significativos, mostrando $p<0,001{ }^{* \star *}$ ). 
Figura 9. Efeito do pep5-cpp em diferentes linhagens celulares.

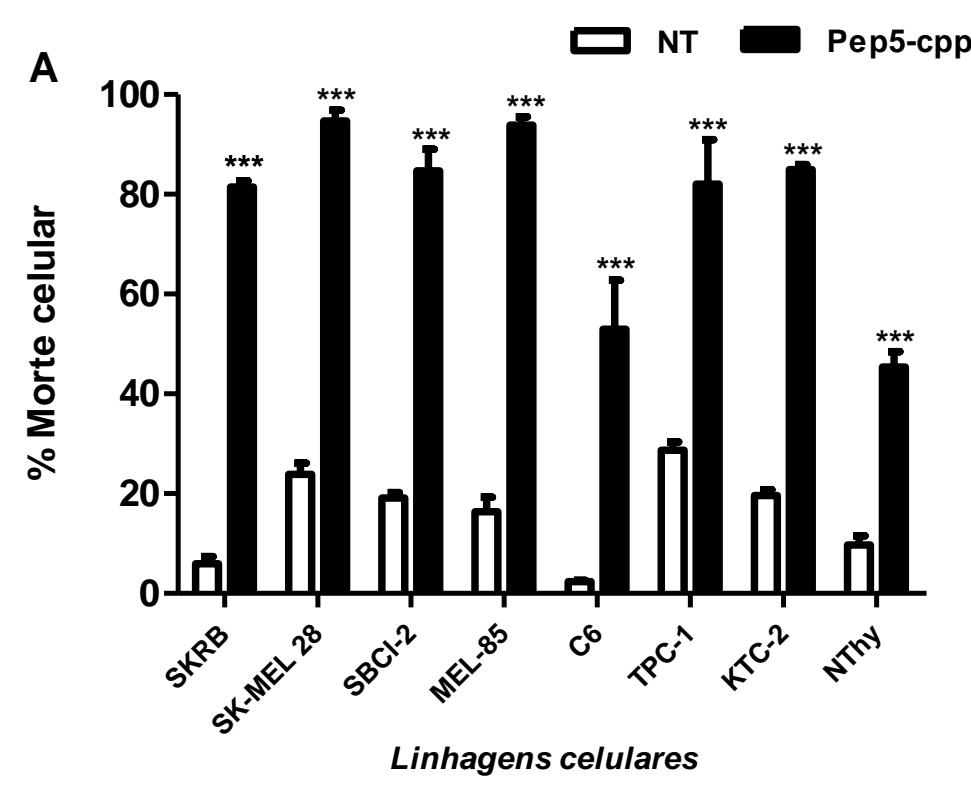

B
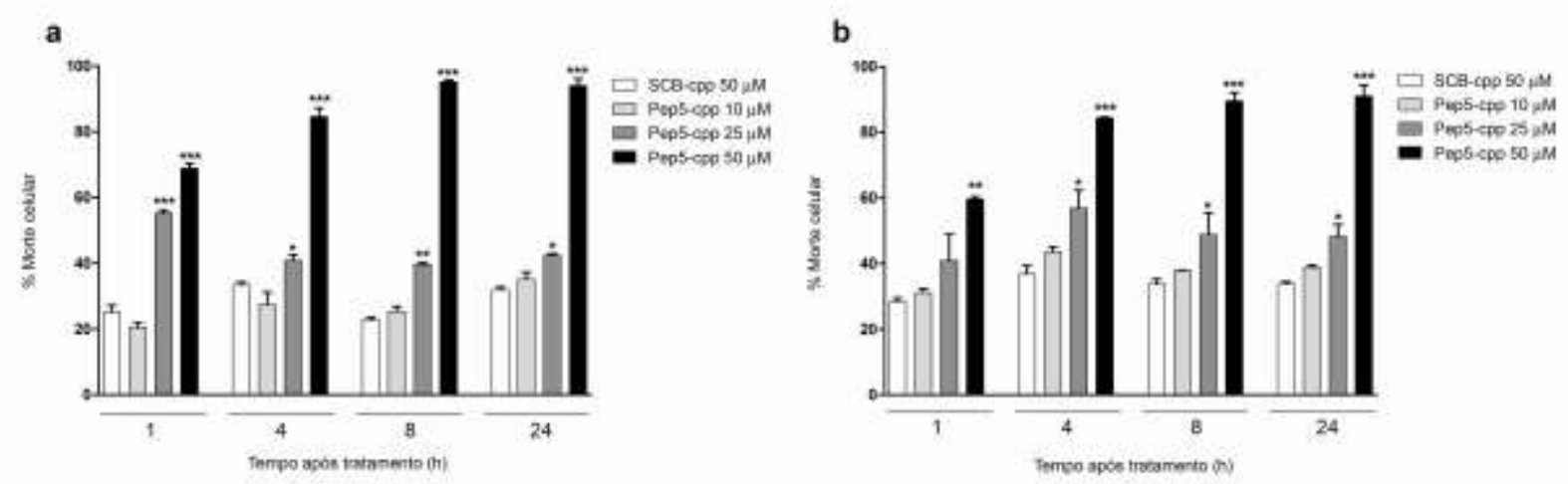

(A) As células foram tratadas ou não com pep5-cpp durante 24 horas (100 $\mu \mathrm{M})$ e, em seguida, analisadas por citometria de fluxo. NT, não tratado. (B) Para as células MDA-MB231 (a) e MCF-7 (b), o tratamento com o pep5-cpp (1-50 $\mu \mathrm{M})$ ou SCB-cpp (50 $\mu \mathrm{M})$ foi realizado em diferentes intervalos de tempo (1 a 24 horas).Os dados representam a média e - SEM de três experimentos realizados de forma independente. Os resultados foram considerados significativos com $p<0,05\left(^{*}\right), p<0,01\left(^{* *}\right)$ ou $p \leq 0,001\left(^{* * *}\right)$. 
Tabela 2. Porcentagem de morte celular induzida pelo pep5-cpp em diferentes tipos celulares.

\begin{tabular}{l|l} 
Linhagem de células & $\begin{array}{c}\text { Porcentagem de morte celular } \\
\text { causada pelo peptídeo pep5-cpp }\end{array}$ \\
\hline SKRB & $81,5 \% \pm 1,2 \%$ \\
\hline SK-MEL-28 & $94,7 \% \pm 2,1 \%$ \\
\hline SBCl-2 & $84,6 \% \pm 4,4 \%$ \\
\hline MEL-85 & $93,8 \% \pm 1,7 \%$ \\
\hline C6 glioma & $52,9 \% \pm 9,7 \%$ \\
\hline TPC-1 & $82,1 \% \pm 8,9 \%$ \\
\hline KTC-2 & $84,9 \% \pm 1,0 \%$ \\
\hline Nthy-ori 3-1 (linhagem celular & $45,3 \% \pm 3,0 \%$ \\
\hline da tireoide normal) & $94,4 \% \pm 1,7 \%$ \\
\hline MDA-MB-231 & $90,3 \% \pm 4,1 \%$ \\
\hline MCF-7 &
\end{tabular}

As células foram tratadas ou não com o pep5-cpp (100 $\mu \mathrm{M})$ durante 24 horas e em seguida analisadas por citometria de fluxo. Para as linhagens MDA-MB-231 e MCF-7 a concentração utilizada foi de $50 \mu \mathrm{M}$.

\subsection{Teste in vivo do pep5-cpp em Glioblastoma de Rato}

Para verificar se o pep5-cpp produzia o mesmo efeito indutor de morte celular in vivo, foi utilizado o modelo de glioblastoma de rato através da injeção de células C6 nos cérebros dos animais. Após 14 dias de crescimento os tumores foram tratados com os peptídeos $\Delta \mathrm{N}$-pep5-cpp ou pep5-cpp (100 $\mu \mathrm{M})$ durante adicionais 14 dias. Através de análises histológicas foi possível verificar que o volume médio do tumor nos animais tratados com o controle era de 6,705 $\pm 1,20 \mathrm{~mm}^{3}$, enquanto que nos animais tratados com o pep5-cpp o volume tumoral era de apenas 3,404 \pm 0,844 $\mathrm{mm}^{3}$ (Figura 10A), sugerindo que pep5-cpp reduziu o volume tumoral em aproximadamente 49\% ( $p=0,0275, n=5)$. Estes dados são semelhantes aos que foram observados quando as células C6 em cultura foram tratadas com este fragmento de ciclina D2. Além disso, a área do tumor tratada com o peptídeo indutor de morte celular apresentou um número bastante aumentado de células fagocitárias, que englobam e digerem restos celulares deixados, generalizadamente aqui chamadas de macrófagos (Figura 10H-K). Isso está de acordo com o fato de ocorrer aumento no número de células mortas na região tratada com o pep5-ccp. 
Figura 10. Efeitos in vivo do $\Delta \mathrm{N}$-pep5-cpp ou pep5-cpp em glioma de rato (C6).
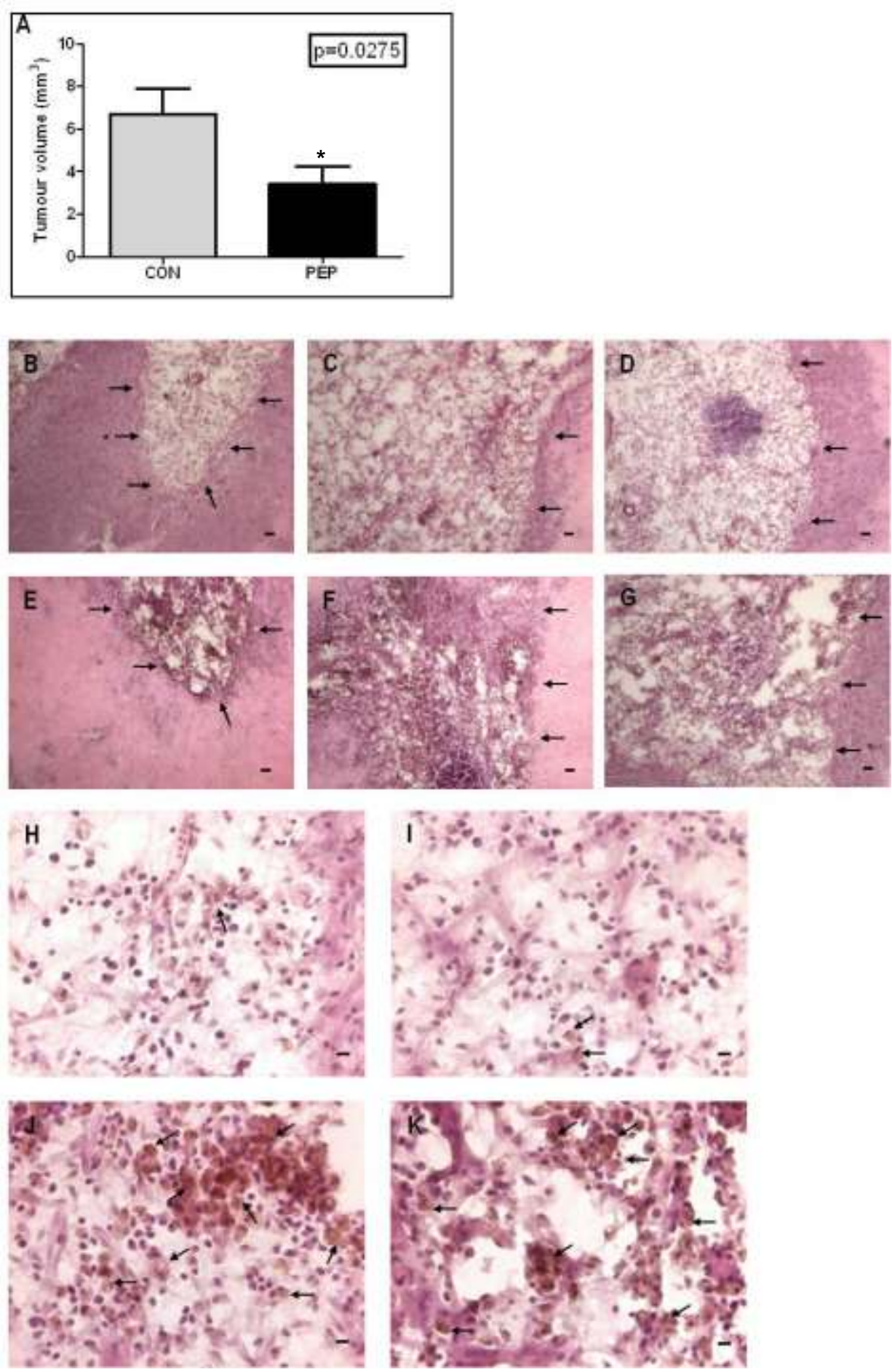

Ratos Wistar machos $(n=5)$ com tumores de 14 dias de crescimento foram tratados com $\Delta \mathrm{N}$-pep5-cpp ou pep5-cpp (100 $\mu \mathrm{M})$ por adicionais 14 dias e após infusão, os animais foram sacrificados por overdose de ketamina-xilazina (Bayer). Após perfusão, os cérebros foram removidos, fixados em formaldeído $4 \%$ e crioprotegidos com $30 \%$ de sacarose em PBS. Os cortes de tecidos congelados $(30 \mu \mathrm{m})$ foram obtidos em micrótomo de congelamento. Os cortes histológicos foram corados com hematoxilina-eosina (HE) e a área do tumor foi avaliada usando um programa de análise de imagens (Image ProPlus, USA). O volume tumoral foi calculado usando a fórmula $V=\pi / 6 \times C \times L \times A$. (A) volume do tumor; (B-D, H, I) $\Delta \mathrm{N}$-pep5-cpp; (E-G, J, K) pep5-cpp; (B-G) as setas indicam as bordas do tumor, barra de 
escala $400 \mu \mathrm{m}$; (J-K) setas indicando células fagocitárias, barra de escala $20 \mu \mathrm{m}$. As análises foram realizadas pelo One-tailed t-test e os resultados foram considerados significativos quando $p<0,0275$.

\subsection{Mecanismos de Morte Celular Induzidos pelo pep5-cpp}

O próximo passo realizado foi verificar qual tipo de morte celular estava sendo induzida pelo pep5-cpp. As células HeLa foram tratadas ou não com o pep5-cpp ou controles e incubadas com anexina $\mathrm{V}$ conjugada a Alexa 488 e iodeto de propídeo. Os resultados sugerem que o pep5-cpp, mas não cpp sozinho, induziu significativamente apoptose e necrose em células HeLa (Figura 11). Após tratamento de 30 min com pep5-cpp, 30\% das células estavam em apoptose, $60 \%$ em necrose, enquanto $\sim 10 \%$ das células permaneceram viáveis (Figura $11 \mathrm{~A}$ ). Resultados semelhantes foram obtidos usando o pep5-cpp ou a sua sequência mínima ativa ( $\Delta \mathrm{C}$-pep5-cpp), que teve três aminoácidos eliminados a partir do Cterminal (Figura 11B). Células HeLa tratadas durante 10 minutos com o pep5-cpp $(50 \mu \mathrm{M})$, não apresentaram nenhuma diferença nos tipos de mortes, comparando-se apoptose vs necrose (Figura 11C).

Tendo em vista que o pep5-cpp causa tanto apoptose como necrose, foi realizado um teste para verificar o efeito deste fragmento protéico sobre a atividade de diferentes caspases. Células HeLa foram tratadas com o peptídeo controle (SCB) ou pep5-cpp $(100 \mu \mathrm{M})$ por 10 minutos e em seguida os lisados foram incubados na presença de substratos específicos para caspases 3/7, 8 e 9 . O grupo de células tratadas com o fragmento de ciclina apresentou um aumento significativo da atividade de caspases 3/7 e 9, quando comparados aos grupos controle e não tratado. Contudo, a atividade da caspase 8 permaneceu inalterada (Figura 12). Estes dados sugerem que o pep5-cpp possa estar induzindo apoptose pela via intrínseca, onde há ativação de caspases 9, 3/7.

Em seguida, a via das proteínas quinases ativadas por mitógenos (MAP Kinases; MAPKs) foi analisada utilizando um array que permite verificar simultaneamente a fosforilação de 26 diferentes proteínas incluindo MAPKs como ERKs, JNK/SAPK e p38 (ZARUBIN; HAN, 2005). Células HeLa foram tratadas com pep5-cpp (100 $\mu \mathrm{M}, 10 \mathrm{~min}$ ) e os extratos celulares analisados de acordo com as instruções do fabricante. Quando comparamos o grupo de células não tratadas com aquele tratado com o pep5-cpp, foi possível observar o aumento da fosforilação de 
algumas MAPKs ou seus alvos, como por exemplo, ERK1/2, HSP27, p38 a/y e p70 S6 kinase. Contudo, o substrato Akt2 teve a sua fosforilação diminuída quando as células foram submetidas ao tratamento com o peptídeo indutor de morte celular (Figura 13A). Resultados semelhantes foram obtidos em outro experimento independente, comparando o efeito do pep5 inativo $(\Delta N$-pep5-cpp) vs o pep5-cpp (Figura 13B). Estes resultados sugerem que o pep5-cpp age alterando a fosforilação de MAPKs específicas e/ou seus substratos.

Como o pep5-cpp causou um grande aumento na porcentagem de células mortas tanto por necrose quanto por apoptose, o efeito de inibidores de morte celular específicos foi avaliado. Quando as células HeLa foram pré-tratadas com os inibidores IM-54 (inibe necrose mediada por estresse oxidativo) ou com a associação de nec-1 (inibe necroptose ativada pelo complexo RIPK1-RIPK3) com qVD (inibidor de caspases), e em seguida submetidas ao tratamento com o pep5cpp $(50 \mu \mathrm{M})$, foi possível observar um bloqueio do efeito indutor de morte celular causado por este peptídeo intracelular.

Enquanto o pep5-cpp sozinho causou $35,16 \pm 0,44 \%$ de morte, os grupos pré-

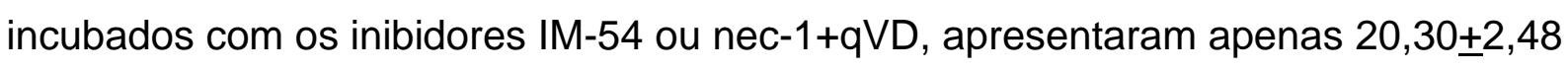
e $20,27 \pm 1,57 \%$ de morte, respectivamente. Esses resultados sugerem que o pep5cpp pode estar interferindo com estas vias de ativação da necrose (Figura 14). Entretanto, o efeito do inibidor de caspases sozinho, ainda não foi verificado. Sendo assim, o mecanismo molecular detalhado responsável pelo efeito indutor de morte celular do pep5-cpp, precisa ser futuramente investigado. 
Figura 11. Análise do mecanismo de morte celular induzido pelo pep5-cpp.
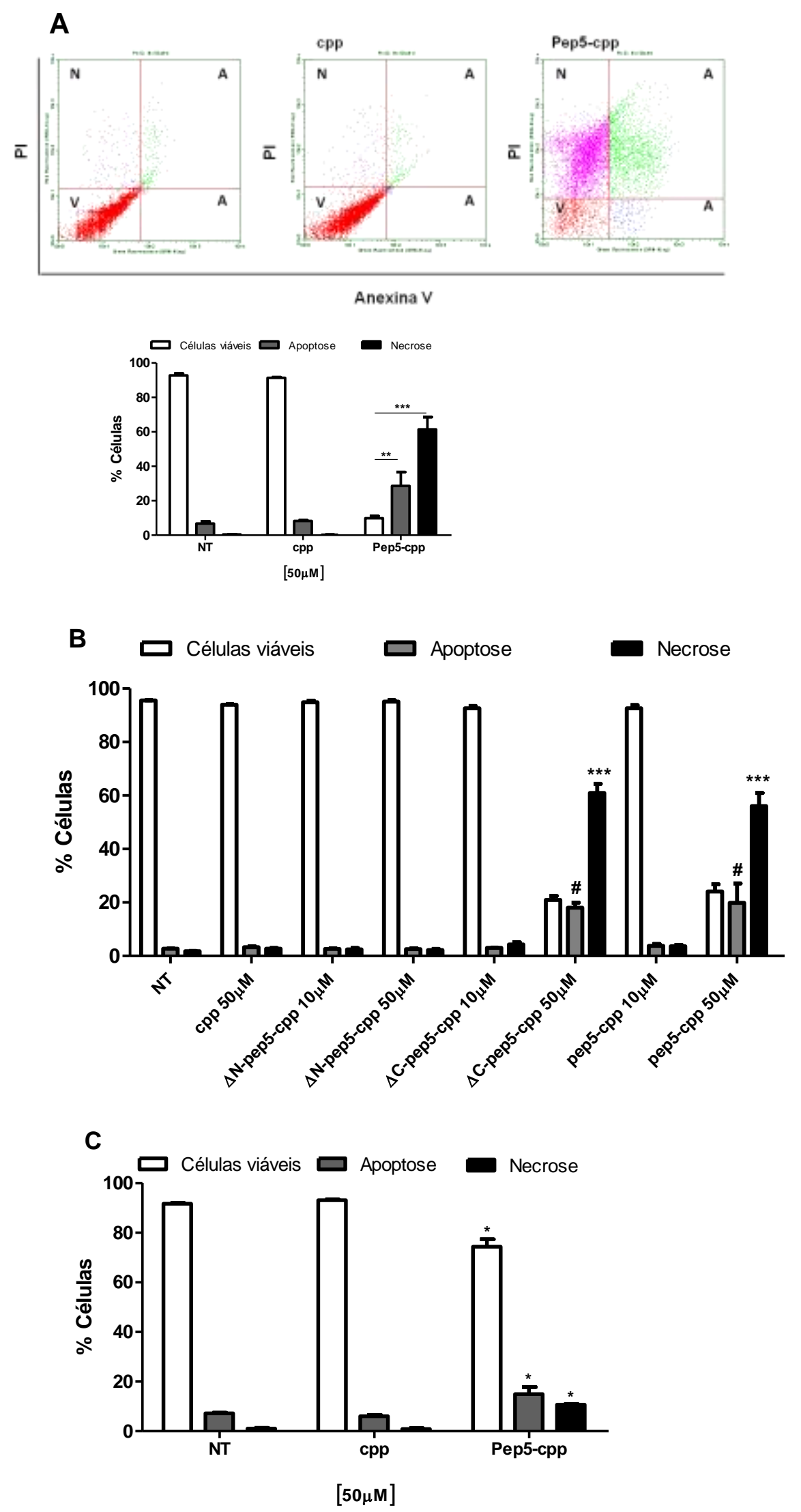

(A-B) As células foram tratadas com o cpp, pep5-cpp ou pep5-cpp modificado (10-50 $\mu \mathrm{M})$, durante 30 ou $10 \mathrm{~min}(\mathrm{C})$ e incubadas com anexina $\mathrm{V}$ e iodeto de propídio. Após o período de incubação (15 min), as amostras foram analisadas por citometria de fluxo. A população 
de células deve ser separada em pelo menos três grupos: células viáveis $(\mathrm{V})$, com baixo nível de fluorescência, as células em apoptose (a) com fluorescência verde substancialmente maior e células necróticas ( $\mathrm{n})$, com maior intensidade de fluorescência vermelha. (NT:. Não tratado, $\Delta \mathrm{N}$ ou Ac-pep5-cpp (pep5 com modificações) Os dados aqui apresentados são representativos de três experimentos realizados em triplicata. Os resultados foram considerados significativos quando $p<0,001\left(^{* * *}\right)$ ou $p<0,05\left(^{*}\right)$.

Figura 12. Ensaio de caspases ativas após tratamento com o pep5-cpp.

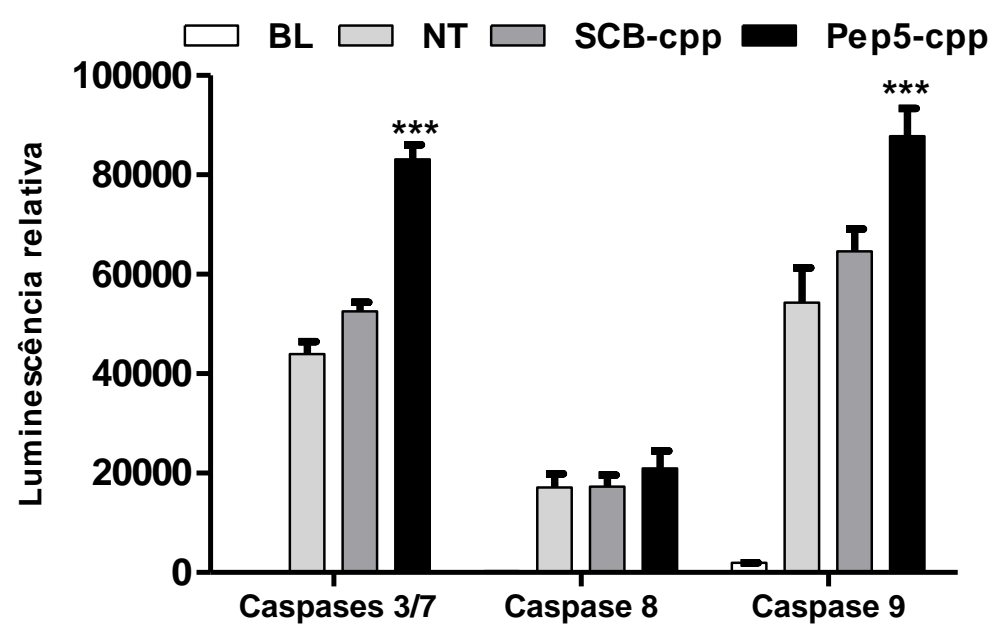

As células foram tratadas com os peptídeos 5 (pep5-cpp) ou SCB (scramble) por 10 minutos $(100 \mu \mathrm{M})$. Após o tratamento, os substratos específicos para diferentes caspases $(3 / 7,8$ e 9$)$ foram adicionados os meio. A luminescência relativa foi lida em luminômetro (Spectramax Molecular Devices). BL, branco. Os dados representam a média \pm SEM de três experimentos independentes realizados em triplicatas, sendo os resultados significativos $\left.\operatorname{com} \mathrm{p} \leq 0.001{ }^{* * *}\right)$. 
Figura 13. Efeito do pep5-cpp na fosforilação de MAPKs específicas ou seus substratos.

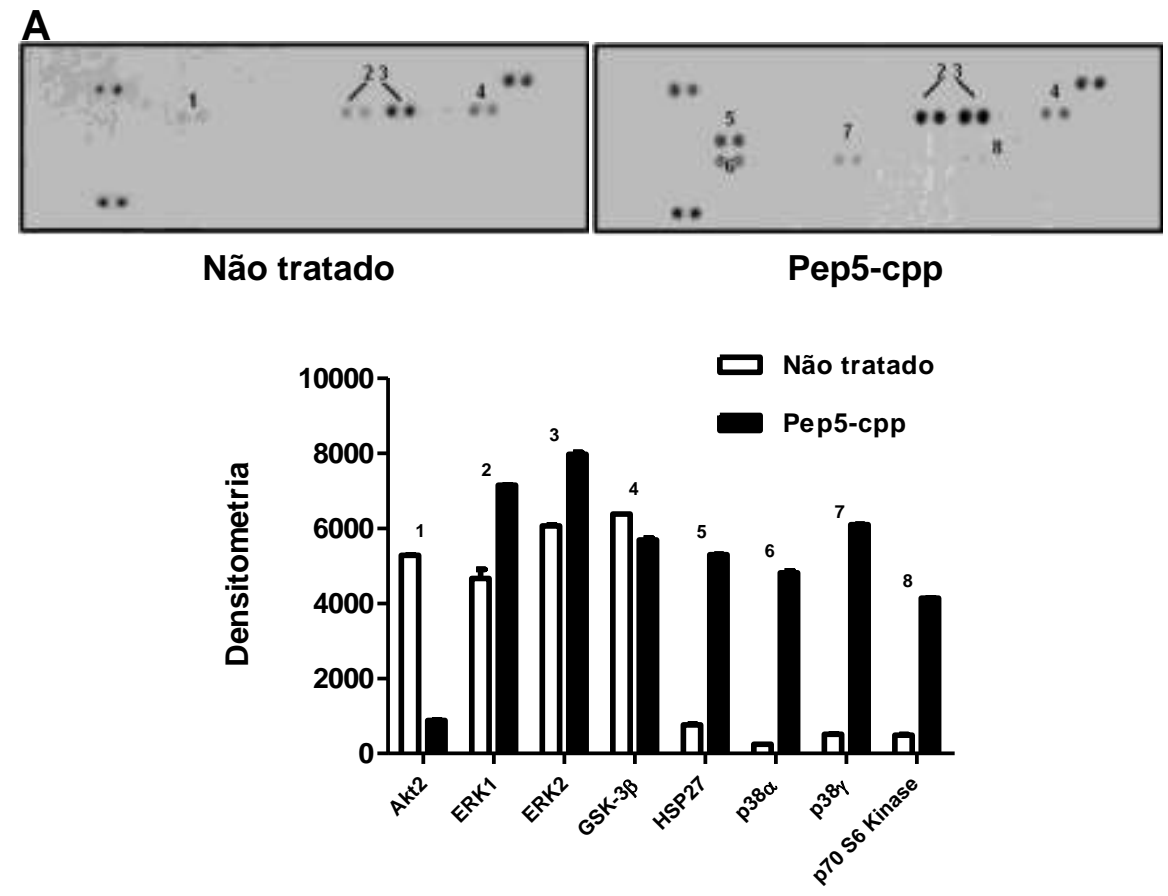

B

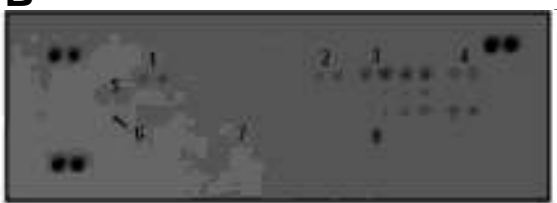

$\Delta \mathrm{N}-\mathrm{Pep5}$-cpp

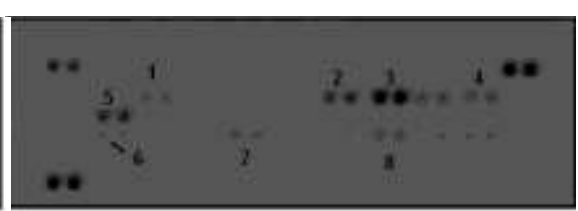

Pep5-cpp

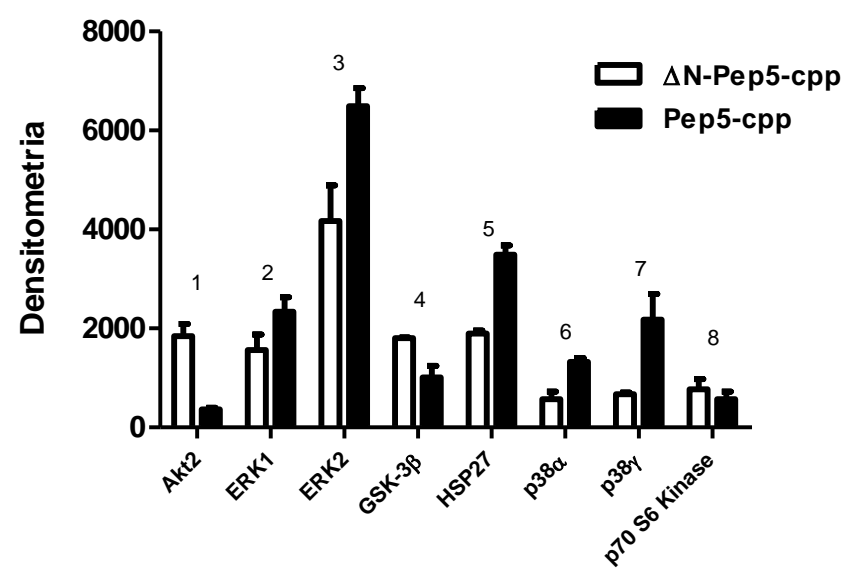

(A) Células HeLa foram tratadas ou não com o pep5-cpp ou (B) $\Delta N$-pep5-cpp por 10 minutos $(100 \mu \mathrm{M})$. Todas as membranas foram incubadas com $200 \mu \mathrm{g}$ de proteínas do lisado total de células. $O$ tempo de exposição das membranas ao filme de Raio $X$ foi de aproximadamente 10 minutos. As quinases e seus substratos contidos no ensaio incluem: Akt1, Akt2, Akt3, Akt pan, CREB, ERK1, ERK2, GSK-3 alfa/beta, GSK-3 beta, HSP27, JNK1, JNK2, JNK3, JNK pan, MKK3, MKK6, MSK2, p38 alfa, p38 beta, p38 delta, p38 gama, p53, p70 S6K, RSK1, RSK2 e TOR. 
Figura 14. Inibidores de morte celular diminuem o efeito do pep5-cpp.

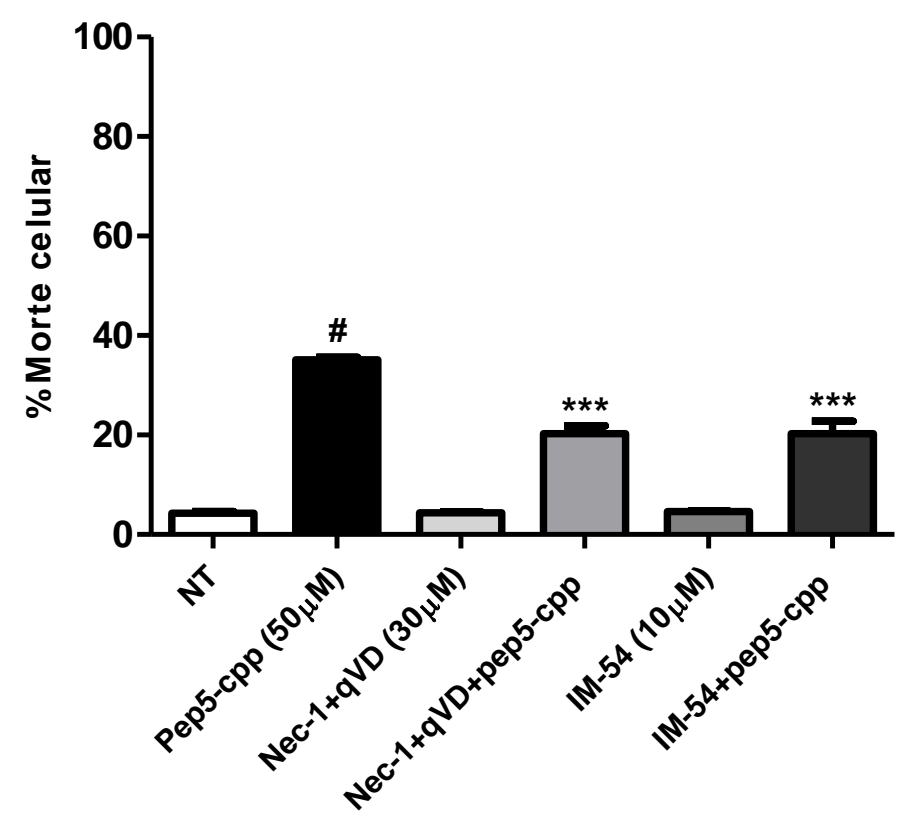

As células HeLa foram pré-incubadas com qVD (inibidor de caspases; $30 \mu \mathrm{M}$ ) e necrostatina 1 (nec-1; inibidor de necroptose; $30 \mu \mathrm{M}$ ) ou com o inibidor de necrose ativada por estresse oxidativo (IM-54; $10 \mu \mathrm{M}$ ) por um período de 1h. Em seguida, foi adicionado pep5-cpp (50 $\mu \mathrm{M})$ aos grupos por adicionais $2 \mathrm{~h}$. As amostras foram fixadas e analisadas por citometria de fluxo. NT: não tratado. (\#) $p \leq 0,001$ em relação ao grupo não tratado. $\left({ }^{* \star *}\right) p \leq 0,001$ em relação ao grupo tratado com o pep5-cpp.

\subsection{Ação do pep5-cpp na Atividade Quimotripsina do Proteassomo}

A capacidade do pep5-cpp atuar sob um dos tipos de atividade proteassomal foi também verificada, tanto quando as células foram tratadas com o pep5-cpp, quanto utilizando o extrato total de células HeLa (in vitro). Após 24 horas de tratamento as células foram lisadas e incubadas com substrato específico do proteassomo. $O$ grupo tratado com o pep5-cpp (100 $\mu \mathrm{M})$ apresentou uma diminuição da atividade do proteassomo, quando comparado com o grupo de células não tratadas (Figura 15A). Efeito semelhante foi observado quando o extrato total foi incubado com o pep5 (sequência original sem o cpp) por $10 \mathrm{~min}$, em diferentes concentrações (Figura $15 B)$. 
Figura 15. Atividade proteolítica do proteassomo em células HeLa tratadas ou não com o pep5-cpp.
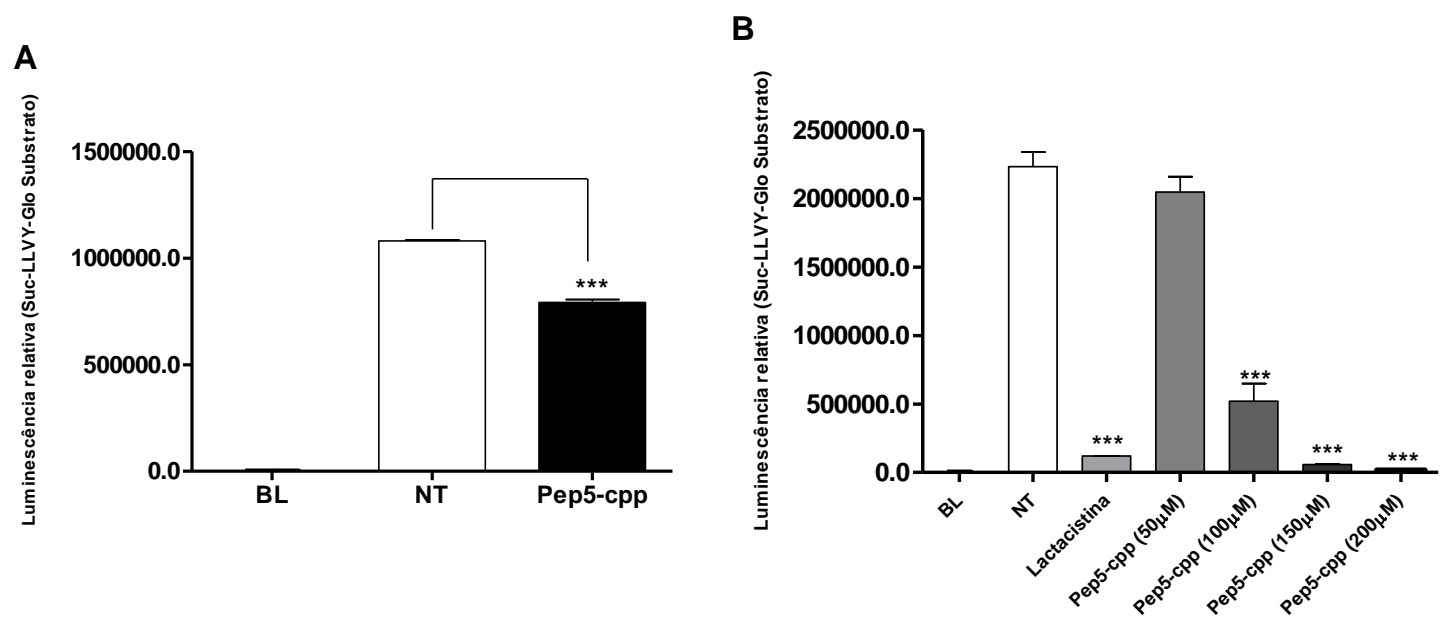

A atividade quimotripsina do proteassomo foi verificada em alíquotas de lisados celulares contendo $20 \mu \mathrm{g}$ de proteínas. A, células HeLa tratadas com o pep5-cpp (100 $\mu \mathrm{M})$ por aproximadamente 24 horas; $\mathbf{B}$, atividade do proteassomo in vitro utilizando extrato total de células HeLa incubado na presença ou ausência do pep5 em diferentes concentrações. Lactacistina $(10 \mu \mathrm{M})$ foi utilizada como controle positivo. NT, não tratado; BL, branco. $\left({ }^{* \star *}\right) \mathrm{p} \leq$ 0,001 em relação ao grupo tratado com o pep5-cpp.

Dessa forma, pode-se concluir que o pep5-cpp pode estar exercendo um efeito de regulação negativa sob a atividade quimotripsina do proteassomo, podendo ser este um mecanismo adicional pelo qual esse peptídeo induz morte celular. 


\section{DISCUSSÃO}

Diversos peptídeos intracelulares foram identificados em células HeLa no presente estudo. As concentrações relativas de dois destes peptídeos foram alteradas em fases específicas do ciclo celular. Esses resultados sugerem que adicionalmente às proteínas, peptídeos intracelulares têm suas concentrações reguladas ao longo do ciclo celular. O peptídeo denominado aqui como "pep5", um fragmento da ciclina D2 (específica da transição $G 1 / S$ ), aumentou na fase $S$ do ciclo celular de células HeLa. Este nonapeptídeo proveniente da ciclina D2 tem uma sequência conservada, com homologia total em humanos, ratos, bovinos, camundongos e aves (NCBI). Quando comparamos a presença do pep5 nos três tipos de ciclinas D (D1, D2, e D3), foi possível observar sua presença apenas na ciclina D2, embora se observe similaridade nessa região entre as três ciclinas (Figura 16).

Figura 16. Alinhamento das sequências de ciclinas $D$.

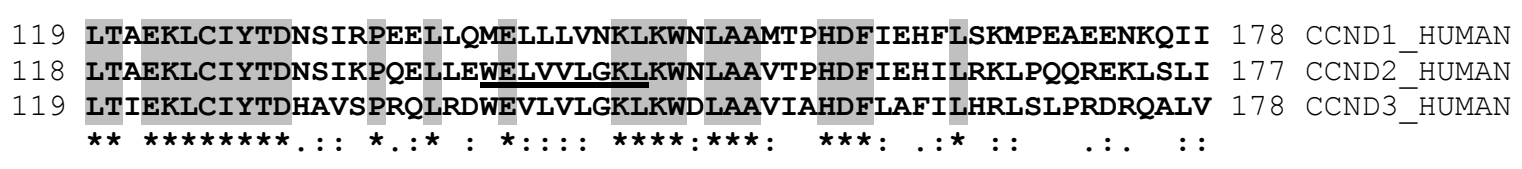

Sequências (FASTA) ou identificadores UniProt das três ciclinas D (CCND1, CCND2 e CCND3). Note a similaridade dos aminoácidos entre os três tipos de ciclinas D1, D2 e D3 em humanos $\left({ }^{*}\right)$. A sequência sublinhada corresponde à identidade do pep5.

Ciclo celular, expressão gênica e apoptose são exemplos de eventos regulados pela clivagem de proteínas específicas pelo sistema ubiquitina proteassomo (UPS), incluindo a degradação de vários fatores de transcrição, ciclinas e inibidores de quinases dependentes de ciclinas (CKIs) (CHUN; MATHIAS; GOEBL, 1996; HERSHKO, 1997). Vários fatores de transcrição, como por exemplo, o NF-kB, estão envolvidos no controle da resposta imune, proliferação e morte celular programada. No desenvolvimento do câncer estas proteínas podem alterar a regulação de outros fatores relacionados à expressão gênica, e assim contribuir para a tumorigênese (KARIN et al., 2002; MURRAY; NORBURY, 2000; SPATARO; NORBURY; HARRIS, 1998). Já as ciclinas são degradadas pelo proteassomo para permitir a saída das 
células da mitose para entrada em um novo ciclo celular e vice-versa (GLOTZER; MURRAY; KIRSCHNER, 1991). Existem cinco classes de ciclinas descritas em mamíferos. As ciclinas $C, D(1,2$ e 3$)$ e $E$ atuam durante a fase $G 1$ e regulam a transição de $\mathrm{G} 1$ para $\mathrm{S}$. Em contraste, as ciclinas A e B (1 e 2) têm atividade durante $S$ e G2, além de serem reguladores da entrada na mitose (KING; JACKSON; KIRSCHNER, 1994; NURSE, 1994; SHERR, 1994). Os níveis de expressão de CKIs incluindo p21, p27 e p57 também são regulados pelo UPS, e este controle é importante para a regulação do ciclo celular (NAKAYAMA, 1998).

$O$ proteassomo tem demonstrado regular a geração da maioria dos peptídeos intracelulares já descritos (FRICKER et al., 2012; GELMAN et al., 2013) e o pep5 demonstrou por meio de análises bioinformáticas ser compatível com a geração proteassomal, seguida de clivagem por aminopeptidase (Figura 17).

Figura 17. Possíveis sítios de clivagem proteassomal para formação do pep5.

\begin{tabular}{|c|c|c|}
\hline Aminoácido & Clivagem proteassomal & Score \\
\hline L & SIM & 0.5983 \\
\hline E & NÃO & 0.0026 \\
\hline W & SIM & 0.5956 \\
\hline E & NÃO & 0.0138 \\
\hline L & SIM & 0.5574 \\
\hline V & NÃO & 0.3662 \\
\hline V & SIM & 0.5282 \\
\hline L & SIM & 0.6835 \\
\hline G & NÃO & 0.0267 \\
\hline K & NÃO & 0.1995 \\
\hline L & SIM & 0.6783 \\
\hline
\end{tabular}

Score > que 0,5 demonstra uma grande probabilidade do proteassomo clivar após o resíduo determinado. (http://imed.med.ucm.es/Tools/pcps/index.html). 
A ciclina D2 precisa ser degradada pelo proteassomo durante a transição G1/S para permitir a progressão do ciclo celular (CHEN et al., 2012), o que sugere que 0 pep5 pode ser endogenamente gerado durante a transição de fase. De fato, o pep5 estava duas vezes aumentado quando células HeLa foram sincronizadas na fase de síntese de DNA (S). A importância de mudanças na concentração endógena deste peptídeo ao longo de um ciclo de divisão celular demanda ainda mais investigações.

Quando as células HeLa foram tratadas com os peptídeos sintetizados (pep3, pep5 ou SCB) foi possível observar que somente um destes peptídeos, o pep5, quando acoplado covalentemente ao cpp, causou um aumento significativo da morte celular. Esses dados sugerem que o efeito produzido pelo pep5 não é na superfície das células, corroborando com a hipótese de um efeito intracelular para essa classe de peptídeos, como anteriormente sugerido pelo nosso grupo. Esse tipo de efeito é distinto daquele observado para os peptídeos clássicos, como bradicinina, gastrina, angiotensinas, insulina, interleucinas, peptídeos opióides, entre outros, que são produzidos intracelularmente e secretados para exercerem suas funções como antagonistas ou agonistas de receptores localizados na membrana celular, não precisando entrar nas células para exercer suas atividades biológicas (BERTI et al., 2012; CUNHA et al., 2008; FERRO; HYSLOP; CAMARGO, 2004; HOKFELT; BARTFAI; BLOOM, 2003; RUSSO et al., 2012).

O pep5 tem uma sequência mínima de seis aminoácidos, a partir do $\mathrm{N}$-terminal, que se mostrou essencial para induzir a morte das células utilizadas neste trabalho. Quando foram retirados três aminoácidos provenientes do C-terminal do pep5, o mesmo manteve a capacidade de induzir morte das células em cultura. Entretanto, a remoção de apenas 1 aminoácido do $\mathrm{N}$-terminal, torna o pep5 inativo, bem como a acetilação do $\mathrm{N}$-terminal reduz sua potência. Isso infere que a atividade do pep5 está relacionada à sua especificidade estrutural para a ativação/inibição de alvos específicos dentro das células. De fato, a regulação de alvos celulares, através da ativação ou inibição de determinadas proteínas, pela interação com pequenos peptídeos, já foi demonstrada. Utilizando peptídeos racionalmente desenhados, derivados de sítios de interação entre enzimas como a proteína quinase $C$ (PKC) e o receptor para PKC ativada, foi evidenciado que estas pequenas moléculas funcionam como inibidores altamente específicos em diversos modelos animais e doenças humanas (CHURCHILL; QVIT; MOCHLY-ROSEN, 2009; RON; LUO; MOCHLY-ROSEN, 1995; ZHANG et al., 1997). 
O possível mecanismo pelo qual este fragmento de ciclina D2, denominado aqui pep5, está promovendo a morte de células em cultura foi investigado. A caracterização inicial da atividade do pep5 na indução de morte celular sugere algumas possibilidades. Durante a morte celular programada por apoptose há participação efetiva de caspases. As caspases $3 / 7$ são chamadas de efetoras e estão envolvidas tanto na ativação da apoptose pela via intrínseca quanto pela via extrínseca. Caspase 8 está envolvida na via extrínseca da apoptose e é ativada pela ligação de um ligante a receptores acoplados a membrana, enquanto caspase 9 participa da via intrínseca e é ativada por perturbações mitocondriais que levam a liberação do citocromo $\mathrm{c}$ e formação de um complexo que culmina na ativação da morte por apoptose (HENGARTNER, 2000; JIN; EL-DEIRY, 2005; LI et al., 1997; PETER; KRAMMER, 2003). Quando células HeLa foram tratadas com o pep5-cpp houve um aumento da atividade de caspases $3 / 7$ e 9, mas não de caspase 8 , o que sugere uma perda de ativação extracelular, via atividade de receptores da morte celular.

Seguindo com a ideia de desvendar o mecanismo pelo qual o pep5 induz morte das células em cultura, os níveis de fosforilação de 26 proteínas envolvidas na via de sinalização das MAPKs foram analisados. Somente seis destas proteínas foram afetadas pelo pep5-cpp, incluindo inibição da fosforilação de Akt2. É sabido que camundongos deficientes de Akt2 apresentam um aumento de morte celular apoptótica na aorta, enquanto que o knockdown de todas as três isoformas de Akt (Akt1/Akt2/Akt3) induz apoptose em diversas linhagens celulares tumorais em humanos (KOSEOGLU et al., 2007). Por outro lado, a superexpressão de Akt2 causa aumento da adesão, invasão e metástase em células cancerígenas do ovário e mama em humanos (ARBOLEDA et al., 2003; SHEN et al., 2013). Outros trabalhos demonstraram que knockdown de Akt2 em células tumorais de pulmão causa simultaneamente clivagem de uma proteína anti-apoptótica, liberação de citocromo c e ativação de caspase (LEE et al., 2011). O pep5-cpp teve um efeito semelhante em células HeLa inibindo a fosforilação de Akt2 e ativando caspase 9. Estes resultados sugerem que parte do mecanismo de morte celular induzido pelo pep5 pode estar sendo mediado pela ativação de caspases 9, 3/7 e inibição de Akt2.

Outras proteínas quinases ativadas por mitógenos, como a p38y e p38a, também tiveram suas fosforilações alteradas na presença do pep5-cpp. A p38, por exemplo, pode ser ativada por diversos fatores, como radiação UV, hipóxia ou 
choque osmótico, e assim, participar da regulação celular (RAMAN; CHEN; COBB, 2007). Células expostas a estresse genotóxico, comumente entram na fase de "ponto de controle" (do inglês, checkpoint), no intuito de reverter as alterações causadas por estes agentes (PINES, 1999). Alguns trabalhos demonstraram que a p38y é amplamente regulada tanto por hipóxia, levando a uma diminuição dos níveis de ciclina D1 em células PC12 e, assim, interferindo com o controle do ciclo celular; bem como por radiação ionizante, a qual induz bloqueio do ciclo celular em células NIH-3T3 (CONRAD et al., 1999; WANG et al., 2000). Além disso, quando p38a é inibida farmacologicamente, utilizando inibidores como o SB202190, as células expostas à radiação UV perdem a capacidade de entrarem no checkpoint durante a transição de G2/M, tanto em modelo animal, quanto em células humanas (BULAVIN et al., 2001). Outras MAPKs como ERK1/2 também foram alteradas na presença do pep5-cpp. A função de ERK1/2, como ativadoras da morte celular, foi primeiramente demonstrada por Bhat e Zhang (1999). Neste trabalho foi demonstrado que a inibição de ERK causava um bloqueio da apoptose induzida por $\mathrm{H}_{2} \mathrm{O}_{2}$ em oligodendrócitos (BHAT; ZHANG, 1999). A ativação de ERK também é importante para promover a morte celular de células HeLa tratadas com cisplatina (WANG; MARTINDALE; HOLBROOK, 2000), bem como a morte de células pancreáticas em ratos, e apoptose de neurônios corticais (LESUISSE; MARTIN, 2002; PAVLOVIC et al., 2000). De alguma forma, o pep5-cpp induz à fosforilação das duas isoformas tanto de p38 quanto de ERK, o que pode estar contribuindo para indução de morte celular mediada por este peptídeo.

Além dos resultados em cultura de células, o pep5-cpp também induziu morte de células tumorais in vivo, quando testado no modelo de glioblastoma de rato. Através de cortes histológicos corados com HE foi possível observar uma diminuição no volume tumoral do grupo tratado com o pep5-cpp quando comparado com aquele tratado com o peptídeo controle, inativo. Também houve aumento do número de células responsáveis pela fagocitose na região tumoral tratada com o pep5-cpp, mas não no grupo controle.

Contudo, o pep5-cpp está ativando além de apoptose a morte celular por necrose. Isto foi observado quando as células HeLa foram tratadas com o pep5-ccp, e em seguida, as células foram submetidas a testes com anexina $\mathrm{V}$ e PI. O número de células PI positivas foi maior do que o número de células anexina $V$ positivas, sugerindo que de alguma forma o pep5-cpp poderia estar induzindo a morte celular 
passando pela apoptose e culminando em uma necrose tardia e acentuada. $O$ inibidor de necrose mediada por estresse oxidativo (IM-54), inibiu o efeito do pep5cpp em células HeLa. Trabalhos demonstraram que células HL60 induzidas à necrose por tratamento com peróxido de hidrogênio, também têm este tipo de morte celular inibida, quando incubadas na presença do IM-54 (DODO et al., 2005; SODEOKA; DODO, 2010). Adicionalmente, foi demonstrado que a morte celular mediada pelo pep5-cpp foi reduzida pela associação dos inibidores nec-1 e qVD. Resultados semelhantes foram observados em modelos animais de lesão cerebral isquêmica, em que o inibidor nec-1 retardou, in vivo, a morte das células neste tipo de lesão (DEGTEREV et al., 2005). Assim, é possível sugerir que inibidores de necrose consigam antagonizar o efeito indutor de morte celular do pep5-cpp.

As células tumorais apresentam um crescimento incontrolado e estão em constante proliferação e divisão, desta forma, como discuto anteriormente, elas degradam proteínas em maior abundância. Por esta razão, a inibição do proteassomo tem sido usada como um agente antitumoral, ajudando a regular o crescimento celular incontrolado e, algumas vezes, induzindo apoptose em diferentes células tumorais (ADAMS et al., 1999; DREXLER, 1997; IMAJOH-OHMI et al., 1995; SUNWOO et al., 2001). O pep5-cpp também demonstrou efeitos inibitórios sobre a atividade quimotripsina do proteassomo. Desta forma, a inibição do proteassomo através de uma regulação negativa poderia estar contribuindo para a indução da morte celular mediada pelo fragmento de ciclina descrito neste trabalho.

Em resumo, estes achados sugerem que peptídeos intracelulares podem representar uma nova classe de moléculas capazes de regular processos como morte e sobrevivência celular. 


\section{CONCLUSÃo}

- Dois peptídeos intracelulares estão aumentados em fases específicas do ciclo celular, quando células HeLa foram sincronizadas com timidina.

- Somente um destes peptídeos, o pep5 (na forma pep5-cpp), apresentou bioatividade induzindo morte celular em diversas linhagens tumorais.

- O pep5-cpp causou alterações na fosforilação de MAPKs específicas ou de seus substratos, além de aumentar a atividade de caspases 3/7 e 9 .

- Este fragmento de ciclina D2 causou morte celular tanto por necrose quanto por apoptose.

- O N-terminal do pep5 é extremamente importante para sua função, mostrando uma relação entre estrutura e atividade.

- In vivo, o pep5-cpp diminuiu o volume de glioblastoma C6 em cérebros de ratos Wistar. 


\section{REFERÊNCIAS*}

ADAMS, J. The proteasome: Structure, function, and role in the cell. Cancer Treat. Rev., v. 29, p. 3-9, 2003. Suppl 1.

ADAMS, J. et al. Proteasome inhibitors: A novel class of potent and effective antitumor agents. Cancer Res., v. 59, n. 11, p. 2615-2622, 1999.

ADAMS, J. M.; CORY, S. The bcl-2 protein family: Arbiters of cell survival. Science, v. 281, n. 5381, p. $1322-1326,1998$.

ALAO, J. P. The regulation of cyclin d1 degradation: Roles in cancer development and the potential for therapeutic invention. Mol. Cancer, v. 6, p. 24, 2007.

ARBOLEDA, M. J. et al. Overexpression of akt2/protein kinase bbeta leads to upregulation of beta1 integrins, increased invasion, and metastasis of human breast and ovarian cancer cells. Cancer Res., v. 63, n. 1, p. 196-206, 2003.

ASHKENAZI, A.; DIXIT, V. M. Death receptors:Signaling and modulation. Science, v. 281, n. 5381, p. 1305-1308, 1998.

BAI, C. et al. Skp1 connects cell cycle regulators to the ubiquitin proteolysis machinery through a novel motif, the f-box. Cell., v. 86, n. 2, p. 263-274, 1996.

BEGLEY, R. et al. Biodistribution of intracellularly acting peptides conjugated reversibly to tat. Biochem. Biophys. Res. Commun., v. 318, n. 4, p. 949-954, 2004.

BEILHARZ, E. J. et al. Mechanisms of delayed cell death following hypoxic-ischemic injury in the immature rat: Evidence for apoptosis during selective neuronal loss. Brain Res. Mol. Brain Res., v. 29, n. 1, p. 1-14, 1995.

BENDA, P. et al. Differentiated rat glial cell strain in tissue culture. Science, v. 161, n. 3839, p. 370-371, 1968.

BENINGA, J.; ROCK, K. L.; GOLDBERG, A. L. Interferon-gamma can stimulate postproteasomal trimming of the $n$ terminus of an antigenic peptide by inducing leucine aminopeptidase. J. Biol. Chem., v. 273, n. 30, p. 18734-18742, 1998.

BEREZNIUK, I. et al. Ccp1/nna1 functions in protein turnover in mouse brain: Implications for cell death in purkinje cell degeneration mice. FASEB J., v. 24, n. 6, p. 1813-1823, 2010.

BERTI, D. A. et al. Analysis of intracellular substrates and products of thimet oligopeptidase in human embryonic kidney 293 cells. J. Biol. Chem., v. 284, n. 21, p. 14105-14116, 2009.

*De acordo com:

ASSOCIAÇÃO BRASILEIRA DE NORMAS TÉCNICAS. NBR 6023: informação e documentação: referências: elaboração. Rio de Janeiro, 2002. 
BERTI, D. A. et al. Identification of intracellular peptides in rat adipose tissue: Insights into insulin resistance. Proteomics, v. 12, n. 17, p. 2668-2681, 2012.

BHAT, N. R.; ZHANG, P. Hydrogen peroxide activation of multiple mitogen-activated protein kinases in an oligodendrocyte cell line: Role of extracellular signal-regulated kinase in hydrogen peroxide-induced cell death. J. Neurochem., v. 72, n. 1, p. 112119, 1999.

BJORKLUND, M. et al. Identification of pathways regulating cell size and cell-cycle progression by rnai. Nature, v. 439, n. 7079, p. 1009-13, 2006.

BOOTSMA, D.; BUDKE, L.; VOS, O. Studies on synchronous division of tissue culture cells initiated by excess thymidine. Exp. Cell. Res., v. 33, p. 301-309, 1964.

BOSSY-WETZEL, E.; NEWMEYER, D. D.; GREEN, D. R. Mitochondrial cytochrome C release in apoptosis occurs upstream of devd-specific caspase activation and independently of mitochondrial transmembrane depolarization. EMBO J., v. 17, n. 1, p. 37-49, 1998.

BRADFORD, M. M. A rapid and sensitive method for the quantitation of microgram quantities of protein utilizing the principle of protein-dye binding. Anal Biochem., v. 72, p. 248-254, 1976.

BULAVIN, D. V. et al. Initiation of a $\mathrm{g} 2 / \mathrm{m}$ checkpoint after ultraviolet radiation requires p38 kinase. Nature, v. 411, n. 6833, p. 102-107, 2001.

BURNS-HAMURO, L. L. et al. Designing isoform-specific peptide disruptors of protein kinase a localization. Proc. Natl. Acad. Sci. U S A, v. 100, n. 7, p. $4072-$ 4077, 2003.

CASTRO, L. M. et al. Similar intracellular peptide profile of tap1/beta2 microglobulin double-knockout mice and c57bl/6 wild-type mice as revealed by peptidomic analysis. AAPS J., v. 12, n. 4, p. 608-616, 2010.

CHARRIAUT-MARLANGUE, C. et al. Ng-nitro-l-arginine methyl ester reduces necrotic but not apoptotic cell death induced by reversible focal ischemia in rat. Eur. J. Pharmacol., v. 310, n. 2-3, p. 137-140, 1996.

CHAUTAN, M. et al. Interdigital cell death can occur through a necrotic and caspaseindependent pathway. Curr. Biol., v. 9, n. 17, p. 967-970, 1999.

CHE, F. Y. et al. Optimization of neuropeptide extraction from the mouse hypothalamus. J. Proteome Res., v. 6, n. 12, p. 4667-4676, 2007.

CHEN, B. B. et al. F-box protein fbxl2 targets cyclin d2 for ubiquitination and degradation to inhibit leukemic cell proliferation. Blood, v. 119, n. 13, p. 3132-3141, 2012.

CHEN, X. et al. Ubiquitin-independent degradation of cell-cycle inhibitors by the reggamma proteasome. Mol. Cell., v. 26, n. 6, p. 843-852, 2007. 
$\mathrm{CHO}, \mathrm{Y}$. S. et al. Phosphorylation-driven assembly of the rip1-rip3 complex regulates programmed necrosis and virus-induced inflammation. Cell., v. 137, n. 6, p. 11121123, 2009.

CHUN, K. T.; MATHIAS, N.; GOEBL, M. G. Ubiquitin-dependent proteolysis and cell cycle control in yeast. Prog. Cell Cycle Res., v. 2, p. 115-127, 1996.

CHURCHILL, E. N.; QVIT, N.; MOCHLY-ROSEN, D. Rationally designed peptide regulators of protein kinase c. Trends Endocrinol. Metab., v. 20, n. 1, p. 25-33, 2009.

CONRAD, P. W. et al. Selective activation of p38alpha and p38gamma by hypoxia. Role in regulation of cyclin d1 by hypoxia in pc12 cells. J. Biol. Chem., v. 274, n. 33, p. 23570-23576, 1999.

CUNHA, F. M. et al. Intracellular peptides as natural regulators of cell signaling. J. Biol. Chem., v. 283, n. 36, p. 24448-24459, 2008.

DEGTEREV, A. et al. Chemical inhibitor of nonapoptotic cell death with therapeutic potential for ischemic brain injury. Nat. Chem. Biol., v. 1, n. 2, p. 112-119, 2005.

DENECKER, G. et al. Apoptotic and necrotic cell death induced by death domain receptors. Cell. Mol. Life Sci., v. 58, n. 3, p. 356-370, 2001.

DICK, T. P. et al. Coordinated dual cleavages induced by the proteasome regulator pa28 lead to dominant mhc ligands. Cell., v. 86, n. 2, p. 253-262, 1996.

DIEHL, J. A. et al. Glycogen synthase kinase-3beta regulates cyclin d1 proteolysis and subcellular localization. Genes Dev., v. 12, n. 22, p. 3499-3511, 1998.

DIEHL, J. A.; ZINDY, F.; SHERR, C. J. Inhibition of cyclin d1 phosphorylation on threonine-286 prevents its rapid degradation via the ubiquitin-proteasome pathway. Genes Dev., v. 11, n. 8, p. 957-972, 1997.

DODD, G. T. et al. The peptide hemopressin acts through cb1 cannabinoid receptors to reduce food intake in rats and mice. J. Neurosci., v. 30, n. 21, p. 7369-7376, 2010.

DODO, K. et al. Inhibition of hydrogen peroxide-induced necrotic cell death with 3amino-2-indolylmaleimide derivatives. Bioorg. Med. Chem. Lett., v. 15, n. 12, p. 3114-3118, 2005.

DOELLING, J. H. et al. The apg8/12-activating enzyme apg7 is required for proper nutrient recycling and senescence in arabidopsis thaliana. J. Biol. Chem., v. 277, n. 36, p. 33105-33114, 2002.

DOMIAN, I. J.; QUON, K. C.; SHAPIRO, L. Cell type-specific phosphorylation and proteolysis of a transcriptional regulator controls the g1-to-s transition in a bacterial cell cycle. Cell., v. 90, n. 3, p. 415-424, 1997. 
DREXLER, H. C. Activation of the cell death program by inhibition of proteasome function. Proc. Natl. Acad. Sci. U S A, v. 94, n. 3, p. 855-860, 1997.

DUBIEL, W. et al. Purification of an $11 \mathrm{~s}$ regulator of the multicatalytic protease. J. Biol. Chem., v. 267, n. 31, p. 22369-22377, 1992.

EMBURY, J. et al. Proteins linked to a protein transduction domain efficiently transduce pancreatic islets. Diabetes, v. 50, n. 8, p. 1706-1713, 2001.

ESKES, R. et al. Bid induces the oligomerization and insertion of bax into the outer mitochondrial membrane. Mol. Cell. Biol., v. 20, n. 3, p. 929-935, 2000.

EVANS, T. et al. Cyclin: A protein specified by maternal mrna in sea urchin eggs that is destroyed at each cleavage division. Cell., v. 33, n. 2, p. 389-396, 1983.

FERRO, E. S.; HYSLOP, S.; CAMARGO, A. C. Intracellullar peptides as putative natural regulators of protein interactions. J. Neurochem., v. 91, n. 4, p. 769-777, 2004.

FOSS, G. S. et al. Constitutive and interferon-gamma-induced expression of the human proteasome subunit multicatalytic endopeptidase complex-like 1. Biochim. Biophys. Acta, v. 1402, n. 1, p. 17-28, 1998.

FRANKEL, A. D.; PABO, C. O. Cellular uptake of the tat protein from human immunodeficiency virus. Cell., v. 55, n. 6, p. 1189-1193, 1988.

FRICKER, L. D. et al. Peptidomic analysis of hek293t cells: Effect of the proteasome inhibitor epoxomicin on intracellular peptides. J. Proteome Res., v. 11, n. 3, p. 19811990, 2012.

FUCHS, Y.; STELLER, H. Programmed cell death in animal development and disease. Cell., v. 147, n. 4, p. 742-758, 2011.

FUKAMI-KOBAYASHI, J.; MITSUI, Y. Cyclin d1 inhibits cell proliferation through binding to pcna and cdk2. Exp. Cell. Res., v. 246, n. 2, p. 338-347, 1999.

GALLO, C. J.; KOZA, R. A.; HERBST, E. J. Polyamines and hela-cell DNA replication. Biochem. J., v. 238, n. 1, p. 37-42, 1986.

GEIER, E. et al. A giant protease with potential to substitute for some functions of the proteasome. Science, v. 283, n. 5404, p. 978-981, 1999.

GELMAN, J. S. et al. Analysis of peptides secreted from cultured mouse brain tissue. Biochim. Biophys. Acta, p. 2408-2417, 2013.

GLICKMAN, M. H.; CIECHANOVER, A. The ubiquitin-proteasome proteolytic pathway: Destruction for the sake of construction. Physiol. Rev., v. 82, n. 2, p. 373428, 2002. 
GLOTZER, M.; MURRAY, A. W.; KIRSCHNER, M. W. Cyclin is degraded by the ubiquitin pathway. Nature, v. 349, n. 6305, p. 132-138, 1991.

GOLDBERG, A. L. Protein degradation and protection against misfolded or damaged proteins. Nature, v. 426, n. 6968, p. 895-899, 2003.

GOLDBERG, A. L. Development of proteasome inhibitors as research tools and cancer drugs. J. Cell. Biol., v. 199, n. 4, p. 583-588, 2012.

GOMES, I. et al. Novel endogenous peptide agonists of cannabinoid receptors. FASEB J., v. 23, n. 9, p. 3020-3029, 2009.

GORDON, P. B.; KOVACS, A. L.; SEGLEN, P. O. Temperature dependence of protein degradation, autophagic sequestration and mitochondrial sugar uptake in rat hepatocytes. Biochim. Biophys. Acta, v. 929, n. 2, p. 128-133, 1987.

GREEN, M.; LOEWENSTEIN, P. M. Autonomous functional domains of chemically synthesized human immunodeficiency virus tat trans-activator protein. Cell., v. 55, n. 6, p. 1179-1188, 1988.

GROLL, M. et al. Structure of 20 s proteasome from yeast at 2.4 a resolution. Nature, v. 386, n. 6624, p. 463-471, 1997.

GROLL, M.; HUBER, R. Purification, crystallization, and x-ray analysis of the yeast 20s proteasome. Methods Enzymol., v. 398, p. 329-336, 2005.

GROLL, M. et al. Probing structural determinants distal to the site of hydrolysis that control substrate specificity of the 20 s proteasome. Chem. Biol., v. 9, n. 5, p. 655662, 2002.

HANAOKA, $H$. et al. Leaf senescence and starvation-induced chlorosis are accelerated by the disruption of an arabidopsis autophagy gene. Plant Physiol., v. 129, n. 3, p. 1181-1193, 2002.

HARDY, K.; HANDYSIDE, A. H.; WINSTON, R. M. The human blastocyst: Cell number, death and allocation during late preimplantation development in vitro. Development, v. 107, n. 3, p. 597-604, 1989.

HARPER, J. V. Synchronization of cell populations in $\mathrm{g} 1 / \mathrm{s}$ and $\mathrm{g} 2 / \mathrm{m}$ phases of the cell cycle. Methods Mol. Biol., v. 296, p. 157-166, 2005.

HARPER, J. W.; BURTON, J. L.; SOLOMON, M. J. The anaphase-promoting complex: It's not just for mitosis any more. Genes Dev., v. 16, n. 17, p. 2179-2206, 2002.

HAUPT, Y. et al. Mdm2 promotes the rapid degradation of p53. Nature, v. 387, n. 6630, p. 296-299, 1997.

$\mathrm{HE}$, S. et al. Receptor interacting protein kinase-3 determines cellular necrotic response to tnf-alpha. Cell., v. 137, n. 6, p. 1100-1111, 2009. 
HEIMANN, A. S. et al. Hemopressin is an inverse agonist of cb1 cannabinoid receptors. Proc. Natl. Acad. Sci. U S A, v. 104, n. 51, p. 20588-20593, 2007.

HEINK, S. et al. Ifn-gamma-induced immune adaptation of the proteasome system is an accelerated and transient response. Proc. Natl. Acad. Sci. U S A, v. 102, n. 26, p. 9241-9246, 2005.

HENGARTNER, M. O. The biochemistry of apoptosis. Nature, v. 407, n. 6805 , p. 770-776, 2000.

HERSHKO, A. Roles of ubiquitin-mediated proteolysis in cell cycle control. Curr. Opin. Cell. Biol., v. 9, n. 6, p. 788-799, 1997.

HERSHKO, A. The ubiquitin system for protein degradation and some of its roles in the control of the cell division cycle. Cell. Death Differ., v. 12, n. 9, p. 1191-1197, 2005.

HOKFELT, T.; BARTFAI, T.; BLOOM, F. Neuropeptides: Opportunities for drug discovery. Lancet. Neurol., v. 2, n. 8, p. 463-472, 2003.

IMAJOH-OHMI, S. et al. Lactacystin, a specific inhibitor of the proteasome, induces apoptosis in human monoblast u937 cells. Biochem. Biophys. Res. Commun., v. 217, n. 3, p. 1070-1077, 1995.

JIN, Z.; EL-DEIRY, W. S. Overview of cell death signaling pathways. Cancer Biol. Ther., v. 4, n. 2, p. 139-163, 2005.

KARIN, M. et al. Nf-kappab in cancer: From innocent bystander to major culprit. Nat. Rev. Cancer, v. 2, n. 4, p. 301-310, 2002.

KERR, J. F.; WYLLIE, A. H.; CURRIE, A. R. Apoptosis: A basic biological phenomenon with wide-ranging implications in tissue kinetics. Br. J. Cancer, v. 26, n. 4, p. 239-257, 1972.

$\mathrm{KIM}, \mathrm{S}$. I. et al. Regulation of cell-surface major histocompatibility complex class $\mathrm{i}$ expression by the endopeptidase ec3.4.24.15 (thimet oligopeptidase). Biochem J., v. 375, n. Pt 1, p. 111-120, 2003.

KING, R. W.; JACKSON, P. K.; KIRSCHNER, M. W. Mitosis in transition. Cell., v. 79, n. 4, p. 563-571, 1994.

KISSELEV, A. F.; AKOPIAN, T. N.; GOLDBERG, A. L. Range of sizes of peptide products generated during degradation of different proteins by archaeal proteasomes. J. Biol. Chem., v. 273, n. 4, p. 1982-1989, 1998.

KISSELEV, A. F. et al. The sizes of peptides generated from protein by mammalian 26 and 20 s proteasomes. Implications for understanding the degradative mechanism and antigen presentation. J. Biol. Chem., v. 274, n. 6, p. 3363-3371, 1999. 
KLOETZEL, P. M. Antigen processing by the proteasome. Nat. Rev. Mol. Cell. Biol., v. 2, n. 3, p. 179-187, 2001.

KOPELMAN, P. G. Obesity as a medical problem. Nature, v. 404, n. 6778, p. 635643, 2000.

KOSEOGLU, S. et al. Akt1, akt2 and akt3-dependent cell survival is cell line-specific and knockdown of all three isoforms selectively induces apoptosis in 20 human tumor cell lines. Cancer Biol. Ther., v. 6, n. 5, p. 755-762, 2007.

KRAMMER, P. H. Cd95's deadly mission in the immune system. Nature, v. 407, n. 6805, p. 789-795, 2000.

KRAMMER, P. H.; ARNOLD, R.; LAVRIK, I. N. Life and death in peripheral t cells. Nat. Rev. Immunol., v. 7, n. 7, p. 532-542, 2007.

KRAVTSOVA-IVANTSIV, Y.; COHEN, S.; CIECHANOVER, A. Modification by single ubiquitin moieties rather than polyubiquitination is sufficient for proteasomal processing of the p105 nf-kappab precursor. Mol. Cell., v. 33, n. 4, p. 496-504, 2009.

KROEMER, G. et al. Classification of cell death: Recommendations of the nomenclature committee on cell death. Cell. Death Differ., v. 12, p. 1463-1467, 2005. Suppl 2.

KUBBUTAT, M. H.; JONES, S. N.; VOUSDEN, K. H. Regulation of p53 stability by mdm2. Nature, v. 387, n. 6630, p. 299-303, 1997.

LABEUR, M. S. et al. Long-term intracerebroventricular corticotropin-releasing hormone administration induces distinct changes in rat splenocyte activation and cytokine expression. Endocrinology, v. 136, n. 6, p. 2678-2688, 1995.

LECKER, S. H.; GOLDBERG, A. L.; MITCH, W. E. Protein degradation by the ubiquitin-proteasome pathway in normal and disease states. J. Am. Soc. Nephrol., v. 17, n. 7, p. 1807-1819, 2006.

LEE, M. W. et al. Roles of akt1 and akt2 in non-small cell lung cancer cell survival, growth, and migration. Cancer Sci., v. 102, n. 10, p. 1822-1828, 2011.

LEIST, M. et al. Tumor necrosis factor-induced hepatocyte apoptosis precedes liver failure in experimental murine shock models. Am. J. Pathol., v. 146, n. 5, p. 1220 1234, 1995.

LEIST, M. et al. Tumor necrosis factor-induced apoptosis during the poisoning of mice with hepatotoxins. Gastroenterology, v. 112, n. 3, p. 923-934, 1997.

LESUISSE, C.; MARTIN, L. J. Immature and mature cortical neurons engage different apoptotic mechanisms involving caspase-3 and the mitogen-activated protein kinase pathway. J. Cereb. Blood Flow Metab., v. 22, n. 8, p. 935-950, 2002. 
LEVINE, B.; KLIONSKY, D. J. Development by self-digestion: Molecular mechanisms and biological functions of autophagy. Dev. Cell., v. 6, n. 4, p. 463-477, 2004.

LEWIS, T. S. et al. Identification of novel map kinase pathway signaling targets by functional proteomics and mass spectrometry. Mol. Cell., v. 6, n. 6, p. 1343-1354, 2000.

LI, F. et al. Apoptotic cells activate the "Phoenix rising" Pathway to promote wound healing and tissue regeneration. Sci. Signal., v. 3, n. 110, p. ra13, 2010.

LI, P. et al. Cytochrome $\mathrm{C}$ and datp-dependent formation of apaf-1/caspase-9 complex initiates an apoptotic protease cascade. Cell., v. 91, n. 4, p. 479-489, 1997.

$\mathrm{LI}, \mathrm{X}$. et al. The src-3/aib1 coactivator is degraded in a ubiquitin- and atp-independent manner by the reggamma proteasome. Cell., v. 124, n. 2, p. 381-392, 2006.

LINDSAY, M. A. Peptide-mediated cell delivery: Application in protein target validation. Curr. Opin. Pharmacol., v. 2, n. 5, p. 587-594, 2002.

LINDSTEN, T. et al. The combined functions of proapoptotic bcl-2 family members bak and bax are essential for normal development of multiple tissues. Mol. Cell., v. 6, n. 6 , p. 1389-1399, 2000.

LIPINSKI, C. A. et al. Experimental and computational approaches to estimate solubility and permeability in drug discovery and development settings. Adv. Drug Deliv. Rev., v. 46, n. 1-3, p. 3-26, 2001.

MA, C. P.; SLAUGHTER, C. A.; DEMARTINO, G. N. Identification, purification, and characterization of a protein activator (pa28) of the $20 \mathrm{~s}$ proteasome (macropain). $\mathbf{J}$. Biol. Chem., v. 267, n. 15, p. 10515-10523, 1992.

MALUMBRES, M.; BARBACID, M. Mammalian cyclin-dependent kinases. Trends Biochem. Sci., v. 30, n. 11, p. 630-641, 2005.

MELENDEZ, A. et al. Autophagy genes are essential for dauer development and lifespan extension in c. Elegans. Science, v. 301, n. 5638, p. 1387-1391, 2003.

MORGAN, D. O. Cyclin-dependent kinases: Engines, clocks, and microprocessors. Annu. Rev. Cell. Dev. Biol., v. 13, p. 261-291, 1997.

MURRAY, R. Z.; NORBURY, C. Proteasome inhibitors as anti-cancer agents. Anticancer Drugs, v. 11, n. 6, p. 407-417, 2000.

NAKAYAMA, K. Cip/kip cyclin-dependent kinase inhibitors: Brakes of the cell cycle engine during development. Bioessays, v. 20, n. 12, p. 1020-1029, 1998.

NASCIMENTO, F. D. et al. Crotamine mediates gene delivery into cells through the binding to heparan sulfate proteoglycans. J. Biol. Chem., v. 282, n. 29, p. 2134921360, 2007. 
NAVON, A.; CIECHANOVER, A. The 26 s proteasome: From basic mechanisms to drug targeting. J. Biol. Chem., v. 284, n. 49, p. 33713-33718, 2009.

NORBURY, C.; NURSE, P. Animal cell cycles and their control. Annu. Rev. Biochem., v. 61, p. 441-470, 1992.

NURSE, P. Ordering s phase and $m$ phase in the cell cycle. Cell., v. 79, n. 4, p. 547550, 1994.

OHTSUBO, M. et al. Human cyclin e, a nuclear protein essential for the g1-to-s phase transition. Mol. Cell. Biol., v. 15, n. 5, p. 2612-2624, 1995.

ORLOWSKI, M. The multicatalytic proteinase complex, a major extralysosomal proteolytic system. Biochemistry, v. 29, n. 45, p. 10289-10297, 1990.

PAGANO, M. et al. Cyclin d1-mediated inhibition of repair and replicative DNA synthesis in human fibroblasts. Genes Dev., v. 8, n. 14, p. 1627-1639, 1994.

PARENTEAU, J. et al. Free uptake of cell-penetrating peptides by fission yeast. FEBS Lett., v. 579, n. 21, p. 4873-4878, 2005.

PAVLOVIC, D. et al. Activation of extracellular signal-regulated kinase (erk)1/2 contributes to cytokine-induced apoptosis in purified rat pancreatic beta-cells. Eur. Cytokine Netw., v. 11, n. 2, p. 267-274, 2000.

PAZ, $P$. et al. Discrete proteolytic intermediates in the mhc class $\mathrm{i}$ antigen processing pathway and mhc i-dependent peptide trimming in the er. Immunity, v. 11, n. 2, p. 241-251, 1999.

PETER, M. E.; KRAMMER, P. H. The cd95(apo-1/fas) disc and beyond. Cell. Death Differ., v. 10, n. 1, p. 26-35, 2003.

PETERS, J. M. The anaphase-promoting complex: Proteolysis in mitosis and beyond. Mol. Cell., v. 9, n. 5, p. 931-943, 2002.

PINES, J. Four-dimensional control of the cell cycle. Nat. Cell. Biol., v. 1, n. 3, p. E73-79, 1999.

PINES, J.; HUNTER, T. The differential localization of human cyclins $a$ and $b$ is due to a cytoplasmic retention signal in cyclin b. EMBO J., v. 13, n. 16, p. 3772-3781, 1994.

PRIVES, C.; HALL, P. A. The p53 pathway. J. Pathol., v. 187, n. 1, p. 112-126, 1999.

QU, X. et al. Promotion of tumorigenesis by heterozygous disruption of the beclin 1 autophagy gene. J. Clin. Invest., v. 112, n. 12, p. 1809-1820, 2003.

RAMAN, M.; CHEN, W.; COBB, M. H. Differential regulation and properties of mapks. Oncogene, v. 26, n. 22, p. 3100-3112, 2007. 
RAMMENSEE, H. G. Survival of the fitters. Nature, v. 419, n. 6906, p. 443-445, 2002.

REITS, E. et al. Peptide diffusion, protection, and degradation in nuclear and cytoplasmic compartments before antigen presentation by mhc class i. Immunity, v. 18, n. 1, p. 97-108, 2003.

REITS, E. et al. A major role for tppii in trimming proteasomal degradation products for mhc class i antigen presentation. Immunity, v. 20, n. 4, p. 495-506, 2004.

RIOLI, V. et al. Novel natural peptide substrates for endopeptidase 24.15 , neurolysin, and angiotensin-converting enzyme. J. Biol. Chem., v. 278, n. 10, p. 8547-8555, 2003.

ROCK, K. L.; GOLDBERG, A. L. Degradation of cell proteins and the generation of mhc class i-presented peptides. Annu. Rev. Immunol., v. 17, p. 739-779, 1999.

RODRIGUEZ, J.; LAZEBNIK, Y. Caspase-9 and apaf-1 form an active holoenzyme. Genes Dev., v. 13, n. 24, p. 3179-3184, 1999.

RON, D.; LUO, J.; MOCHLY-ROSEN, D. C2 region-derived peptides inhibit translocation and function of beta protein kinase $\mathrm{c}$ in vivo. J. Biol. Chem., v. 270, n. 41, p. 24180-24187, 1995.

RUSSO, L. C. et al. Inhibition of thimet oligopeptidase by sirna alters specific intracellular peptides and potentiates isoproterenol signal transduction. FEBS Lett., v. 586, n. 19, p. 3287-3292, 2012.

SARIC, T. et al. Major histocompatibility complex class i-presented antigenic peptides are degraded in cytosolic extracts primarily by thimet oligopeptidase. J. Biol. Chem., v. 276, n. 39, p. 36474-36481, 2001.

SCHWARZE, S. R.; DOWDY, S. F. In vivo protein transduction: Intracellular delivery of biologically active proteins, compounds and DNA. Trends Pharmacol. Sci., v. 21, n. 2, p. 45-48, 2000.

SHAIK, S. et al. Protein degradation in cell cycle. eLS. John Wiley \& Sons Ltd. Chichester 2012.

SHEAFF, R. J. et al. Proteasomal turnover of p21cip1 does not require p21cip1 ubiquitination. Mol. Cell., v. 5, n. 2, p. 403-410, 2000.

SHEN, Y. H. et al. Akt2 confers protection against aortic aneurysms and dissections. Circ. Res., v. 112, n. 4, p. 618-632, 2013.

SHERR, C. J. Mammalian g1 cyclins. Cell., v. 73, n. 6, p. 1059-1065, 1993.

SHERR, C. J. G1 phase progression: Cycling on cue. Cell., v. 79, n. 4, p. 551-555, 1994. 
SHERR, C. J.; ROBERTS, J. M. Cdk inhibitors: Positive and negative regulators of g1-phase progression. Genes Dev., v. 13, n. 12, p. 1501-1512, 1999.

SODEOKA, M.; DODO, K. Development of selective inhibitors of necrosis. Chem. Rec., v. 10, n. 5, p. 308-314, 2010.

SOLOMON, M. J. et al. Cyclin activation of p34cdc2. Cell., v. 63, n. 5, p. 1013-1024, 1990.

SOUGHAYER, J. S. et al. Characterization of tat-mediated transport of detachable kinase substrates. Biochemistry, v. 43, n. 26, p. 8528-8540, 2004.

SPATARO, V.; NORBURY, C.; HARRIS, A. L. The ubiquitin-proteasome pathway in cancer. Br. J. Cancer, v. 77, n. 3, p. 448-455, 1998.

SPRADLING, A. C. et al. The berkeley drosophila genome project gene disruption project: Single p-element insertions mutating $25 \%$ of vital drosophila genes. Genetics, v. 153, n. 1, p. 135-177, 1999.

STADTMUELLER, B. M.; HILL, C. P. Proteasome activators. Mol. Cell., v. 41, n. 1, p. 8-19, 2011.

STAROSTINA, N. G. et al. Crl2(Irr-1) targets a cdk inhibitor for cell cycle control in c. Elegans and actin-based motility regulation in human cells. Dev. Cell., v. 19, n. 5, p. 753-764, 2010.

SU, T. T. et al. Exit from mitosis in drosophila syncytial embryos requires proteolysis and cyclin degradation, and is associated with localized dephosphorylation. Genes Dev., v. 12, n. 10, p. 1495-1503, 1998.

SUNWOO, J. B. et al. Novel proteasome inhibitor ps-341 inhibits activation of nuclear factor-kappa b, cell survival, tumor growth, and angiogenesis in squamous cell carcinoma. Clin. Cancer Res., v. 7, n. 5, p. 1419-1428, 2001.

SURAWEERA, A. et al. Failure of amino acid homeostasis causes cell death following proteasome inhibition. Mol. Cell., v. 48, n. 2, p. 242-253, 2012.

SUZUKI, R. et al. Proteasomal turnover of hepatitis $c$ virus core protein is regulated by two distinct mechanisms: A ubiquitin-dependent mechanism and a ubiquitinindependent but pa28gamma-dependent mechanism. J. Virol., v. 83, n. 5, p. 23892392, 2009.

THORNBERRY, N. A.; LAZEBNIK, Y. Caspases: Enemies within. Science, v. 281, n. 5381, p. 1312-1316, 1998.

TYAGI, M. et al. Internalization of hiv-1 tat requires cell surface heparan sulfate proteoglycans. J. Biol. Chem., v. 276, n. 5, p. 3254-3261, 2001. 
UDENFRIEND, S. et al. Fluorescamine: A reagent for assay of amino acids, peptides, proteins, and primary amines in the picomole range. Science, v. 178, n. 4063, p. 871-872, 1972.

USTRELL, V. et al. Pa200, a nuclear proteasome activator involved in DNA repair. EMBO J., v. 21, n. 13, p. 3516-3525, 2002.

VANDENABEELE, $P$. et al. Molecular mechanisms of necroptosis: An ordered cellular explosion. Nat. Rev. Mol. Cell. Biol., v. 11, n. 10, p. 700-714, 2010.

VANLANGENAKKER, N. et al. Tnf-induced necroptosis in 1929 cells is tightly regulated by multiple tnfr1 complex i and ii members. Cell. Death Dis., v. 2, p. e230, 2011.

VODERMAIER, H. C. Apc/c and scf: Controlling each other and the cell cycle. Curr. Biol., v. 14, n. 18, p. R787-796, 2004.

WACLAW, R. R.; CHATOT, C. L. Patterns of expression of cyclins a, b1, d, e and cdk 2 in preimplantation mouse embryos. Zygote, v. 12, n. 1, p. 19-30, 2004.

WADIA, J. S.; DOWDY, S. F. Protein transduction technology. Curr. Opin. Biotechnol., v. 13, n. 1, p. 52-56, 2002.

WANG, G. et al. Resolving rotational motions of nano-objects in engineered environments and live cells with gold nanorods and differential interference contrast microscopy. J. Am. Chem. Soc., v. 132, n. 46, p. 16417-16422, 2010.

WANG, H. Y. et al. Induction of cd4(+) t cell-dependent antitumor immunity by tatmediated tumor antigen delivery into dendritic cells. J. Clin. Invest., v. 109, n. 11, p. 1463-1470, 2002.

WANG, X.; MARTINDALE, J. L.; HOLBROOK, N. J. Requirement for erk activation in cisplatin-induced apoptosis. J. Biol. Chem., v. 275, n. 50, p. 39435-39443, 2000.

WANG, X. et al. Involvement of the mkk6-p38gamma cascade in gamma-radiationinduced cell cycle arrest. Mol. Cell. Biol., v. 20, n. 13, p. 4543-4552, 2000.

WARDMAN, J.; FRICKER, L. D. Quantitative peptidomics of mice lacking peptideprocessing enzymes. Methods Mol. Biol., v. 768, p. 307-323, 2011.

WENDER, P. A. et al. The design, synthesis, and evaluation of molecules that enable or enhance cellular uptake: Peptoid molecular transporters. Proc. Natl. Acad. Sci. U S A, v. 97, n. 24, p. 13003-13008, 2000.

YAGLOM, J. et al. P34cdc28-mediated control of cln3 cyclin degradation. Mol. Cell. Biol., v. 15, n. 2, p. 731-741, 1995.

YANG, J. et al. Prevention of apoptosis by bcl-2: Release of cytochrome c from mitochondria blocked. Science, v. 275, n. 5303, p. 1129-1132, 1997. 
YOULE, R. J.; STRASSER, A. The bcl-2 protein family: Opposing activities that mediate cell death. Nat. Rev. Mol. Cell. Biol., v. 9, n. 1, p. 47-59, 2008.

YUE, Z. et al. Beclin 1, an autophagy gene essential for early embryonic development, is a haploinsufficient tumor suppressor. Proc. Natl. Acad. Sci. U S A, v. 100, n. 25, p. 15077-15082, 2003.

ZARUBIN, T.; HAN, J. Activation and signaling of the p38 map kinase pathway. Cell. Res., v. 15, n. 1, p. 11-18, 2005.

ZHANG, D. W. et al. Rip3, an energy metabolism regulator that switches tnf-induced cell death from apoptosis to necrosis. Science, v. 325, n. 5938, p. 332-336, 2009.

ZHANG, Z. H. et al. C2 region-derived peptides of beta-protein kinase c regulate cardiac ca2+ channels. Circ. Res., v. 80, n. 5, p. 720-729, 1997.

ZHOU, J. Y. et al. Analysis of microrna expression profiles during the cell cycle in synchronized hela cells. BMB Rep., v. 42, n. 9, p. 593-598, 2009.

ZIEGLER, A. et al. The cationic cell-penetrating peptide $\operatorname{cpp}$ (tat) derived from the hiv1 protein tat is rapidly transported into living fibroblasts: Optical, biophysical, and metabolic evidence. Biochemistry, v. 44, n. 1, p. 138-148, 2005. 